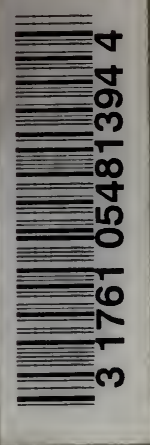

THE

GENERAL CHARACTERS

$$
\text { T. }
$$

S. B. SCHRYVER, Th.D, D.SE 


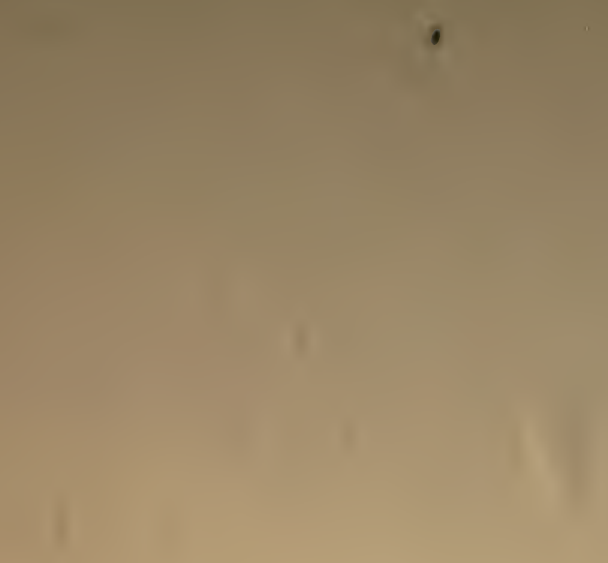

$=x$

I

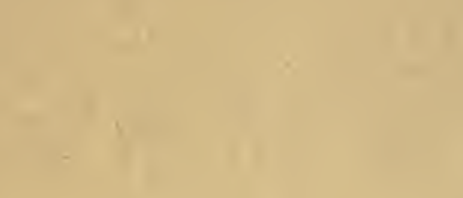






\section{MONOGRAPHS ON BIOCHEMISTRY}

EDITED BY

R. H. ADERS PLIMMER, D.SC.

AND

F. G. HOPKINS, M.A., M.B., D.Sc., F.R.S. 


\section{MONOGRAPHS ON BIOCHEMISTRY. \\ Royal 8vo, boards.}

\section{THE DEVELOPMENT AND PRESENT POSI-}

TION OF BIOLOGICAL CHEMISTRY. By F. Gowland Hopkins, M.A., M.B., D.Sc., F.R.S.

THE NATURE OF ENZYME ACTION. By W. M. BAYLISS, D.Sc., F.R.S. 3s. net.

THE CHEMICAL CONSTITUTION OF THE PROTEINS. By R. H. Aders Plimmer, D.Sc. In Two Parts. Part I., 3s. net; Part II., 2s. 6d. net.

THE GENERAL CHARACTERS OF THE PROTEINS. By S. B. Schryver, Ph.D., D.Sc., 2s. 6d. net.

THE VEGETABLE PROTEINS. By Thomas B. OsBorne, Ph.D.

THE POLYSACCHARIDES. By ARthur R. Ling, F.I.C.

GLUCose AND THE GLUCOSIDES. By E. Frankland Armstrong, D.Sc., Ph.D.

THE FATS. By J. B. Leathes, D.Sc.

COLLOIDS. By W. B. Hardy, M.A., F.R.S.

LONGMANS, GREEN, AND CO.

LONDON, NEW YORK, BOMBAY, AND CALCUTTA. 
THE

\section{GENERAL CHARACTERS}

OF

\section{THE PROTEINS}

BY

S. B. SCHRYVER, Ph.D., D.Sc.

LECTURER ON PHYSIOLOGICAL CHEMISTRY, UNIVERSITY COLLEGE, LONDON
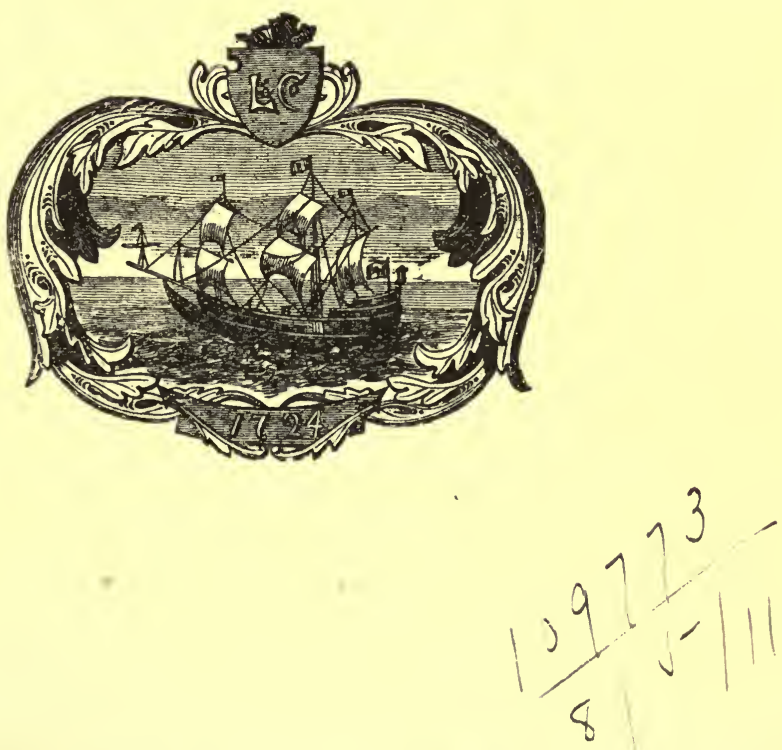

L O NGMANS, GREEN, AND C O.

39 PATERNOSTER ROW, LONDON NEW YORK, BOMBAY, AND CALCUTTA 



\section{GENERAL PREFACE.}

THE subject of Physiological Chemistry, or Biochemistry, is enlarging its borders to such an extent at the present time, that no single text-book upon the subject, without being cumbrous, can adequately deal with it as a whole, so as to give both a general and a detailed account of its present position. It is, moreover, difficult, in the case of the larger text-books, to keep abreast of so rapidly growing a science by means of new editions, and such volumes are therefore issued when much of their contents has become obsolete.

For this reason, an attempt is being made to place this branch of science in a more accessible position by issuing a series of monographs upon the various chapters of the subject, each independent of and yet dependent upon the others, so that from time to time, as new material and the demand therefor necessitate, a new edition of each monograph can be issued without re-issuing the whole series. In this way, both the expenses of publication and the expense to the purchaser will be diminished, and by a moderate outlay it will be possible to obtain a full account of any particular subject as nearly current as possible.

The editors of these monographs have kept two objects in view : firstly, that each author should be himself working at the subject with which he deals; and, secondly, that a Bibliography, as complete as possible, should be included, in order to avoid cross references, which are apt to be wrongly cited, and in order that each monograph may yield full and independent information of the work which has been done upon the subject.

It has been decided as a general scheme that the volumes first issued shall deal with the pure chemistry of physiological products and with certain general aspects of the subject. 
Subsequent monographs will be devoted to such questions as the chemistry of special tissues and particular aspects of metabolism. So the series, if continued, will proceed from physiological chemistry to what may be now more properly termed chemical physiology. This will depend upon the success which the first series achieves, and upon the divisions of the subject which may be of interest at the time.

R. H. A. P.

F. G. H. 


\section{PREFACE.}

In the following pages an attempt is made to review the chief properties of the proteins, with the object of determining how far they are of value for devising methods of isolation and identification of individual members of the class.

In view of the limited scope of the essay, certain aspects of the subject have been purposely treated in a somewhat empirical manner. No attempt, for example, has been made to explain such processes as "salting out" or heat coagulation; subjects such as these may be more fittingly discussed in a monograph dealing with the general chemical physics of colloids.

In spite of the great advances recently made in the knowledge of the physics and of the constitution of proteins, the methods available for their isolation and identification are still very unsatisfactory in character. This fact may serve as an apology for the tentative treatment of certain sections of this book; the importance of the subject, however, both to chemists and physiologists, may warrant the issue of this monograph, dealing, as it does, with a part of protein chemistry still in a rudimentary state of development.

S. B. S. 



\section{CONTENTS.}

INTRODUCTION • •

\section{PART I.}

THE PHYSICAL PROPERTIES OF THE PROTEINS.

SECTION

I. The Solubility of Proteins in Salt Solutions; The "Salting Out" from Solutions . . . . . 8

II. The Degree of Solubility of Proteins in Salt SoluTIONS

III. Solubility of Proteins in Organic Solvents • • $\mathrm{i} 6$

IV. Separation of Proteins from Solution by PrecipitANTS Other than SALts . . . . . . . I 7

V. Crystallisation of Proteins $\quad . \quad . . \quad$. $\quad . \quad$. 18

VI. The Temperature of Heat Coagulation of Protein Solutions . . . . . . . . . $2 \mathrm{I}$

VII. Optical Rotation of Protein Solutions . . $\quad 24$

ViII. Molecular Weight Determinations by Cryoscopic Methods . . . . . . . . . . 24

IX. The Electrolytic Conductivity of Protein Solutions 26

X. The "Gold Number" . . . . . . . . 27

XI. The Fractional Filtration of Proteins . . " 28 
PART II.

THE GENERAL CHEMICAL CHARACTERS OF THE PROTEINS.

SECTION

XII. The Qualitative Reactions of the Proteins . . 30

XiII. The Chemical Composition of Proteins. The Nitrogen

Content and Distribution . . . . $\quad . \quad 32$

XIV. The Sulphur, Phosphorus and Halogen Content of

Proteins . . . . . . . . 36

XV. The Tyrosine Factor of Proteins . . . . 38

XVI. Salt Formation by Proteins. Combination with Acids AND BASES .

XViI. The Precipitation of Proteins by Salts of the Heavy

Metals . . . . . . . . 56

XVIII. The Oxidation of the Proteins . $. \quad . \quad . \quad 58$

XiX. The Action of Halogens on Proteins . . . 6 I

XX. The Action of Nitrous Acid on Proteins . • • 67

XXI. Action of Formaldehyde on Proteins • • • 69

PART III.

BIOLOGICAL METHODS FOR THE IDENTIFICATION AND DIFFERENTIATION OF PROTEINS.

XXII. The Precipitin Reaction . . . . . . 7 I

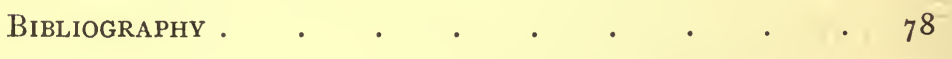

$\operatorname{INDEX} \cdot \quad \cdot \quad \cdot \quad \cdot \quad \cdot \quad \cdot \quad \cdot \quad \cdot \quad 8_{5}$ 


\section{INTRODUCTION.}

THE proteins belong for the most part to that class of bodies which Graham has designated the "colloids," to which the ordinary criteria available for the identification and differentiation of simpler organic compounds, such as boiling points, melting points, etc., are generally inapplicable. The want of knowledge of the physical nature of colloids has been one of the chief obstacles to advances in the experimental investigations of the proteins. The principal problem affected thereby is that of the separation of the proteins from one another and from other substances. The proteins, furthermore, are substances of large molecular weight, yielding on degradation a great number of products, the isolation and quantitative estimation of which have taxed the ingenuity of the chemist to the utmost.

The investigations on the proteins may be consequently divided into two main classes: (i) those connected with the elucidation of their physical properties as colloids, with which are associated the names of Hardy in this country, and of Hofmeister, Spiro, Pauli and many others on the continent; (ii) those connected with their chemical constitution, with which are associated the names of Emil Fischer and of Kossel and their pupils. A short review of certain aspects of protein chemistry in the light of the more recent advances will be advisable before proceeding to a more detailed discussion of those properties which may be utilised in the processes for the isolation and identification of individual substances belonging to the class.

\section{Isolation AND SeParation of the Proteins.}

Proteins derived from different sources have markedly different properties. Some are soluble in water, others are insoluble in pure water, but soluble in saline solutions; others, again, are soluble in alcohol. Advantage was taken of these differences for the separation of proteins from one another, especially in the earlier work on the vegetable proteins.

Another property, viz., that of precipitability from aqueous solutions by the addition of neutral salts, also received early attention, and the difference in behaviour of solutions of different proteins as regards precipitability was soon turned to account in devising a method of separation. It is of interest in this place to quote the words of Dénis, the first investigator who systematically employed the method of "salting out". On the title-page of his monograph, Mémoire sur le sang, published in 1856 , but containing results of work commenced many years before this date, he describes his researches as "Études faites suivant la méthode d'experimentation par les sels, la 
seule qui, dans l'état actuel de la science, semble pouvoir être appliqué avec fruits à des réserches sur ces substances". " Although these words were written more than forty years ago, when the protein investigations were still in their infancy, they contain a statement which is substantially true to-day, for the process of "salting out" is the only one which is capable of general application for the separation of the proteins. Like the analogous processes of fractional distillation and fractional precipitation, the process of fractional "salting out" seldom leads to a complete separation of mixtures. The efficiency and the gradual development of the technique is discussed in that section of this work, which, owing to the actual and historical importance of the subject, precedes all others dealing with the general character of the proteins. It has purposely been treated in a somewhat empirical fashion; the physical nature of the process will, it is hoped, be dealt with in greater detail in a later volume of this series.

\section{The Chemical Nature of the Proteins.}

Although it was clearly recognised that the nitrogenous matters obtainable from plants and animals varied considerably in their physical properties, such as in solubility, appearance, etc., it was nevertheless held by Liebig that only one protein existed. The differences in the nitrogenous substances obtained from various sources were ascribed entirely to variations in physical coniditions. The slight differences in empirical composition in the preparations obtained accounted, no doubt, for this view of Liebig. Mulder, to whom many valuable observations are due, expressed later a similar view in a somewhat modified form. Referring to "protein" he remarks: "It exists in various forms, being either soluble or insoluble in water. It forms different compounds with sulphur or with phosphorus or both -and hence the differences it presents in appearance and physical properties. The substance has received the name of 'protein' because it is the origin of so many dissimilar bodies, and is itself a primary substance" (Mulder, Vegetable and Physiological Chemistry, p. 29I. English translation, I845-49).

Subsequent investigations have shown that these early views of Liebig and Mulder are incorrect, more especially the careful and reliable experiments of Schützenberger, Hlasiwetz and Habermann, Horbaczewski, Schulze and Barbieri and others, most of which were carried out thirty years or more after the publication of the abovequoted words of Mulder. It is unnecessary to enter into detail in this place as to the results of the experiments on the hydrolysis of the proteins, due to these and other workers, culminating subsequently in the elaboration by $\mathrm{E}$. Fischer and his pupils of an approximately quantitative method for the isolation of the hydrolysis products; these are discussed in the volume devoted to this subject. Suffice it here to say that the individual proteins have been found to differ from one another both qualitatively and quantitatively as regards the aminoacids which they yield on hydrolysis.

Modern work tends to confirm the theory due to Hofmeister that 1i.e., proteins. 
the proteins are built up by the condensation of several amino-acids according to the scheme-

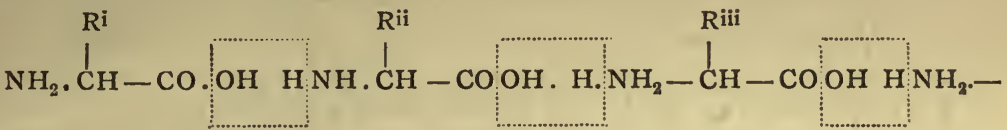

$$
\begin{aligned}
& \ldots-\mathrm{COOH} \quad \mathrm{H}_{\mathrm{NH}_{2}} \cdot \stackrel{\mathrm{CH}}{\mathrm{CH}} \cdot \mathrm{COOH}
\end{aligned}
$$

thereby forming a class of products which have been designated the polypeptides by Fischer. Such polypeptides are held to form the essential part of the structure of the protein molecule; the latter may, however, contain other groups, such as phosphoric acid, and possibly also carbohydrates; as to whether such groups form an essential part of the actual protein molecule, or whether they are held in loose combination in the form of what Hoppe-Seyler described as "prosthetic groups," need not be discussed in detail here. There is, however, a certain amount of evidence that phosphoric acid, in the case of caseinogen, for example, forms an essential part of the molecule. Whatever view may be held as to the other groups, there is little doubt that the polypeptide group forms the essential part of the protein molecule, and that it is formed by the conjugation of different amino acids in the different individual members of the protein class.

\section{The Relative Value of the Various Physical and Chemical Characters for Fixing the Identity OF a Protein Considered in the Light of Present KNOWLEDGE.}

As already mentioned, the majority of the proteins differ from one another but slightly in their empirical chemical constitution; the numbers obtained by the ultimate chemical analysis are therefore, as a rule, of but little value for the characterisation of proteins. The most obvious method for differentiation of the proteins is that of the quantitative estimation of hydrolysis products. This process, however, yields reliable results only when relatively large quantities of material are available for examination, and it requires, furthermore, considerable expenditure of time. In actual practice, such as in physiological and pathological research, or in the investigation of foodstuffs, it is, as a rule, quite inapplicable ; it affords, moreover, no certain criterion as to the homogeneity or heterogeneity of the substance under investigation.

On the assumption, then, that the protein is a polypeptide, it remains to be considered what chemical and physical properties may most fittingly serve for its characterisation.

\section{The Acid and Basic Functions of the Protein Molecule and their Relations to the Physical Properties.}

The discussion of the above question will be facilitated by the consideration of the properties of a typical polypeptide, e.g., the tetrapeptide :- 
<smiles>[R12]C(N)C(=O)NC([R17])C(=O)NC([R12])C(=O)O</smiles>

The presence of both an amino and a carboxyl group would indicate the possibility of the formation of two kinds of salts, viz., salts with acids and salts with bases. The acidity or basicity of a protein is the property which most obviously requires investigation. If all were constituted like the substance of the formula given above, with $\mathrm{R}^{\mathrm{i}}, \mathrm{R}^{\mathrm{ii}}, \ldots \mathrm{R}^{\mathrm{iv}}$ representing simple radicals, containing only carbon and hydrogen, each molecule of protein would react chemically with one molecule of acid or one molecule of base. In practice, however, the problem of the acidity or basicity is not so simple as might at first sight appear. In the first place, proteins do not yield on hydrolysis simple monoamino acids; other products of a more basic character are obtainable, such as arginine, lysine (which is a simple diamino acid) and histidine. Similarly on hydrolysis proteins yield amino acids containing more than one carboxylic acid group, such as aspartic acid, glutamic acid, etc. Simple polypeptides, yielding either strongly acid or basic amino acids on hydrolysis, could be represented by the typical formula, in which $R^{i}, R^{i i}$, etc., instead of representing simple radicals of carbon and hydrogen, would represent radicals in which one or more hydrogen atoms are substituted by a carboxyl or amino group.

The existence of such extra amino or carboxyl groups gives rise to a further possible complication, for they can condense with carboxyl and amino groups of other polypeptides, and thus give rise to substances of highly complex molecular structure with branching chains of polypeptide nature. The proteins, considered as polypeptides, which yield on hydrolysis both diamino- and dicarboxylic acids, can act, therefore, either as basic or acidic bodies, according to whether the amino or carboxyl groups predominate. ${ }^{1}$

As a matter of fact, certain proteins, such as the protamines, first described by Miescher, have very strongly marked basic characters; these substances yield on hydrolysis more than 80 per cent. of basic products, and the molecules contain, therefore, a large predominance of amino groups. Other proteins are of distinctly acid character,

${ }^{1}$ Nothing is known as to the stereochemical configuration of proteins. H. E. and E. F. Armstrong have suggested that the main polypeptide can assume a spiral form, and have constructed models to represent it according to this hypothesis. In this case the more reactive groups might be represented as the freely moving groups external to the spiral. The stereochemical configuration would probably also affect the reactivity of the amino and carboxyl groups; adopting the Armstrong configuration it is conceivable that those which are external to the spiral would be reactive, and those protected by groups of other atoms inert. Furthermore, it is conceivable that certain stereochemical configurations would be favourable to the formation of imino groups through the elimination of ammonia from contiguous amino groups, or of acid anhydrides by elimination of water from carboxyl groups, diminishing the basicity in the former and the acidity in the latter case. It is therefore not possible to predict the acidic or basic character of the protein from the mere estimation of the hydrolysis products, ascertaining thus whether diamino or dicarboxylic groups predominate, as stereochemical configura. tion may render either sets of groups inactive. Furthermore, a certain amount of ammonia is obtainable from most proteins on hydrolysis (see p. 33); this is assumed to be derived by the hydrolysis of acid amides containing the group $-\mathrm{CO}-\mathrm{NH}_{2}$. The existence of such groups would diminish the acidity due to the presence of carboxyl groups. 
such as some of the globulins and caseinogen, although this character may be ascribed in the latter substance to the presence of the phosphoric acid group in the molecule.

The majority of the proteins, however, have neither marked basic nor acidic character, and in this respect resemble the typical polypeptide of the typical formula with the radicals $R^{i}, R^{i i}$, etc., containing only carbon and hydrogen atoms.

The determination of the acidity and basicity of proteins of this character has entailed many difficulties. This arises from the capacity of proteins as colloids to adsorb simpler substances and from the large molecular weights of this class of substances and relatively small number of active carboxylic and amino groups ; the equivalent combining weight is therefore large; in the case of the crude eggalbumins Sjöqvist has shown (p. 40) that between 800 and 900 grams of protein combine with I gram mol. equivalent of hydrochloric acid to form the hydrochloride salt.

Now a solution which contains a relatively large percentage of a solute of large molecular weight is technically very dilute; on the assumption that the protein of egg-white is a mono-acid base, its molecular weight would be about 850 , which, according to the experiments of Sjöqvist, is the lowest possible ; a 5 per cent. solution would be therefore only $\frac{1}{170}$ normal. The salts of weak bases in dilute solution readily undergo hydrolysis according to the equation-

$$
\text { B. } \mathrm{HCl}+\mathrm{HOH}=\mathrm{B} \cdot \mathrm{OH}+\mathrm{HCl} \text {. }
$$

The acidity or basicity of a protein cannot, as a rule, be determined, therefore, by titration with the use of indicators, since hydrolysis of salts can take place in solutions containing relatively large amounts of protein.

Furthermore, Hardy has pointed out in the case of the globulins the possibility of the formation of basic salts. If serum-globulin be submitted to dialysis (see p. 54) it can hydrolyse according to the equation-

$$
x \mathrm{GH} \overline{\mathrm{Ac}}+y \mathrm{HOH}=(\mathrm{GHOH})_{y}(\mathrm{GH} \overline{\mathrm{Ac}})_{x-y}+y \mathrm{HAc} .
$$

Where $\overline{\mathrm{Ac}}$ represents an acid ion. As $y$ increases, the protein becomes more and more basic, and the negative ion increases in size, the change being indicated by the alteration in the appearance of the solution, which becomes gradually more and more opalescent until it is finally nearly opaque. It has still more or less the properties of a true solution, the opacity being due to the formation of what Hardy calls pseudo-ions, which can still take part in the transport of electricity, and which, on increasing hydrolysis, become so large as to be capable of diffracting light. A basic salt is finally obtained containing a very small amount of acid.

The above considerations have an important bearing upon the choice of constants to be chosen for the characterisation of proteins, for it will be obviously impossible to directly determine in most cases whether a given solution contains a free protein or a salt of the same. Indicators, as already stated, are useless for the purpose, and owing to the possibility of the formation of acid or basic salts very minute quantities of an acid or base will very often suffice to entirely alter the character of a solution. There exists, therefore, very great 
difficulty in obtaining reliable physical constants for proteins, for the physical differences between free bases and free acids, and the salts obtainable therefrom, are, in the case of almost all physical constants, very considerable. To indicate but one instance: Leucine as a free base has an optical rotation of $[a]_{\mathrm{D}}^{20}=-10^{\circ} 42^{\circ}$, whereas the rotation of its hydrochloride is $[a]_{D}^{20}=+1533^{\circ}$ in 20 per cent. hydrochloric acid.

Electrolytic conductivity, osmotic pressure, and many other physical properties are also profoundly affected by the above considerations, and attention has been called in the following pages to the circumstances which so often render physical determinations unreliable.

There is still one other disturbing influence to be noted. Owing to the amphoteric character of the proteins, and their capacity to form salts with acids and bases, they can also conceivably form compounds with neutral salts. Now colloids have a considerable power of adsorbing other bodies, a circumstance which also, as already mentioned, considerably affects the determinations of the acidic and basic functions of a protein. It is seldom, if ever, that an ash-free protein is obtainable, and it is impossible to determine whether the ash represents inorganic substance in actual combination, e.g., sodium in the form of a sodium salt, or whether it owes its origin to bodies which have been physically adsorbed; the mineral substances present have, under any circumstances, a great influence on the physical properties of the protein.

The above considerations render the majority of the physical properties extremely unreliable for the characterisation of the proteins; the precipitability by salts is, alone amongst the properties generally determined, but slightly affected by them.

\section{Chemical Characteristics.}

It is upon the chemical properties, therefore, that reliance must be chiefly placed for obtaining constants for the characterisation of proteins.

The most reliable of these are undoubtedly the numbers representing the distribution of nitrogen in the molecule, and generally known as the "Hausmann numbers". These indicate the relative proportions of nitrogen in the molecule combined in the form of amide, of monoamino acids, and of basic bodies. ${ }^{1}$ They are discussed in detail on pp. 33-36.

The number of "active" 2 amino groups also varies in the different proteins; to determine these Dr. Horace Brown has suggested the determination of the "amino-index" (p. 67). Another suggestion for the determination of this factor is due to Messrs. Cross, Bevan and Briggs (p. 65). The capacity also for forming halogen derivatives varies considerably in the different proteins; the halogen numbers should serve also as a method of characterisation. Furthermore, different proteins yield different quantities of hydrolysis 
products, which can be readily estimated quantitatively without the employment of the elaborate esterification method. Amongst these cystine can be estimated by determination of the sulphur content of the protein, and tyrosine by the method suggested by Millar (p. 38). The cystine and tyrosine factors should therefore be of value.

Much work remains to be done in the elaboration of quantitative reactions which might serve for the characterisation of the proteins. It is not necessary that these reactions should lead always to the formation of definite chemical compounds; it would be sufficient if standard conditions could be chosen, under which a definite amount of chemical reaction should take place. Similar methods have been employed in the case of the fats, as an instance of which may be cited the so-called Hübl iodine number. This indicates approximately the number of double bonds in a given fat, but it is generally admitted that the addition of iodine at the double bonds is accompanied by a certain amount of substitution. Under defined conditions, however, the amount of iodine absorbed is a constant for each particular fat.

Similar reactions are required for the identification of proteins, and the various suggestions which have been made in this respect have received what will be, it is hoped, adequate consideration in the following pages. 
PART I.

\section{THE PHYSICAL PROPERTIES OF THE PROTEINS.}

\section{Section I.-The Solubility of Proteins in Salt Solutions; The "Salting OUt" From Solutions.}

THE method which has been most commonly employed hitherto, for the separation of proteins from one another and from other bodies is that commonly known as "salting out". It was noticed as long ago as 1853 by Panum that dry sodium chloride does not precipitate egg-white in the cold, whereas blood-serum gives a distinct precipitate which redissolves in distilled water. Claude Bernard had also observed that pancreatic juice yielded a precipitate with magnesium sulphate; Robin and Verdeil (1853) made a similar observation with ascitic fluid. The latter investigators noticed also that magnesium sulphate gave a precipitate with egg-white and with serum, the filtrate from which coagulated on heating, whereas the filtrate from a similar precipitate with pancreatic juice did not.

Virchow, in the following year, carried out further investigations on this subject, and found that, besides magnesium sulphate, other salts, such as potassium sulphate, sodium sulphate, alum, calcium chloride, sodium chloride, possess the property of precipitating proteins; he also made the fundamental observation that the precipitates formed by salts redissolved in water, and that the solutions thus obtained behaved as true protein solutions. $\mathrm{He}$ confirmed also the French observers, in noticing that the salt does not always precipitate the whole of the protein, and he assumed that the latter must exist in solution in different conditions. At this time the existence of several kinds of protein was unknown, and Virchow did not recognise the fact that many such bodies could exist, and that their different behaviour towards salt solutions was a factor which could be employed for a partial separation, at any rate, of one protein from another.

Dénis ${ }^{1}$ first clearly discriminated between proteins in this respect. He noticed that some are readily soluble in salt solutions, which are insoluble in water. He found, for example, that certain proteins are soluble in 10 per cent. sodium chloride, potassium nitrate, and sodium sulphate solutions at $30^{\circ} \mathrm{C}$., from which they could be reprecipitated on dilution with water; he studied also the precipitation of proteins from blood-serum by saturation with neutral salts, employing for this purpose sulphate of sodium, chloride of sodium, and sulphate of magnesium. Dénis must be regarded, therefore, as

1 Dénis had commenced his investigations on the proteins in 1835 . His monographs on the subject were published in 1856 and 1859 . 
the pioneer in the systematic separation of the proteins by the method of "salting out".

Dénis included in his investigations not only proteins of animal origin, but also bodies of a similar nature derived from plants. To those proteins which are soluble in 10 per cent. sodium chloride solution, from which they can be precipitated on dilution (especially after saturation of the diluted solution with $\mathrm{CO}_{2}$ ), Hoppe-Seyler gave the name of "globulins". They formed the subject of an investigation carried out in Hoppe-Seyler's laboratory by his pupil Weyl (I877), by whom the general reactions were clearly defined. To this class belong vitellin, the protein derived from egg-yolk, the protein first isolated from striated muscle by Kühne, and called by him myosin, the serum-globulin, and various plant proteins. Weyl divided the globulins into two classes, viz., those which are soluble in sodium chloride of high concentration ("vitellins") and those which can be precipitated from the Io per cent. solution by saturation. with more salt ("myosins"). ${ }^{1}$

In addition to this work from Hoppe-Seyler's laboratory, numerous other researches on the separations of proteins by salt precipitation appeared between the years I865 and I885.

Hammarsten investigated the precipitation of serum by sodium chloride and magnesium sulphate, which only precipitate a fraction of the proteins; his investigations were supplemented by those of Heynsius, ${ }^{2}$ who some years later (1884) called attention to the great precipitating power of ammonium sulphate; in this respect it is far superior to the corresponding sodium salt, which Starke (in Hammarsten's laboratory) and independently, Schäfer, had a short time previously shown possessed the power of precipitating proteins in the filtrate from the magnesium sulphate precipitate.

As a result of these various investigations, two classes of precipitating salts were introduced into general use for the separation of proteins, viz., magnesium sulphate and sodium chloride, which precipitate the so-called "globulin" fraction, and ammonium sulphate, which precipitates from the filtrate the "albumin" fraction.

By the systematic application of these salts by Halliburton to the separation of natural proteins of serum, muscle and milk, much light was thrown on the constituents of animal tissues and fluids.

Halliburton showed that serum could be separated into its constituents by salts other than those already mentioned; he found, for example, that sodium nitrate, sodium acetate and sodium carbonate could also precipitate serum-globulin, whilst potassium acetate and potassium phosphate precipitated from serum all the heat-coagulable proteins. He also applied the method of salt precipitation to investigations on muscle-plasma and milk. He concluded that in the former several proteins existed, whereas in the latter only two could be recognised, viz., casein (or, as it is now termed, caseinogen) and lact-albumin.

Another application of the salt precipitation about this period deserves to be mentioned. Wenz showed, in 1886 , that peptones were not precipitated by ammonium sulphate, and Kühne and Chittenden utilised this observation for separating the proteoses

\footnotetext{
1 The present classification of the proteins is given in Dr. Plimmer's monograph.

2 Ammonium sulphate had also been previously employed by Méhu.
} 
from the peptones, both classes of bodies being intermediate degradation products of natural proteins produced by means of digestive enzymes.

Owing to the unsatisfactory technique of using several salts, Kauder, in 1886 , for the first time carried out a fractional precipitation of protein bodies, employing only one salt, viz., ammonium sulphate. This research was undertaken under the direction of Hofmeister, who, with his pupils, made valuable contributions during the course of the next few years to the technique and knowledge of salt precipitation.

Kauder showed that the globulin precipitation in a serum solution commenced when ammonium sulphate is present to the extent of 24-29 per cent. of cornplete saturation, and ended when the saturation amounted to $36-46$ per cent. ${ }^{1}$ On filtering off the precipitate thus produced and adding fresh quantities of ammonium sulphate, no further precipitation took place until the degree of saturation reached about 64 per cent. At this point the albumin fraction commenced to be precipitated; this precipitation was completed when the degree of saturation reached 90 per cent. The point at which precipitation of the various fractions commences and ends varies somewhat; it depends to a slight extent on the concentration of the serum solution employed and its reaction.

A series of systematic investigations was also carried out in Hofmeister's laboratory with the object of determining the relative value of various salt solutions as precipitants. The following determinations are due to Lewith, who worked with the serum proteins :-

\begin{tabular}{|c|c|c|c|c|c|}
\hline $\begin{array}{l}\text { I. } \\
\text { Salt. }\end{array}$ & $\begin{array}{l}\text { II. } \\
\text { Strength of } \\
\text { Protein }\end{array}$ & Globul & Precipitation. & Albu & in Precipitation. \\
\hline $\mathrm{Na}_{2} \mathrm{SO}$ & $\begin{array}{l}\text { Ser Cent. } \\
\text { Po*98 }\end{array}$ & $\begin{array}{c}\text { Begins. } \\
\mathrm{II}_{4}\end{array}$ & Ends. & Begins. & Ends. \\
\hline$\left(\mathrm{NH}_{4}\right)_{2} \mathrm{SO}_{4}$ & . 0.99 & 14.2 & $23 \cdot I$ & $33 \cdot 6$ & $47 \cdot 2$ \\
\hline Na Acetate & - $2 \cdot 26$ & 14 & - & - & - \\
\hline Mgs" & $\begin{array}{l}\cdot .98 \\
. \quad 0.98\end{array}$ & $\begin{array}{l}15 \% \\
16 \% 9\end{array}$ & $25 \cdot 7$ & E & 二 \\
\hline K Acetate & . $2 \cdot 26$ & $\times 7.6$ & $35^{\circ}$ & $64 \cdot 6$ & More than $82^{\circ} \cdot 2$ \\
\hline $\mathrm{NaCl}$. & $\begin{array}{l}\cdot 0.98 \\
: \quad 1.66\end{array}$ & $\begin{array}{l}22 \cdot 8 \\
21 \cdot 8\end{array}$ & Not estimated & 60.8 & 88.1 \\
\hline $\mathrm{KCl}$ & . $r \cdot 04$ & $25 \cdot 9$ & - & - & - \\
\hline $\mathrm{NaNO}_{3}$ & - 0.98 & $46 \cdot 7$ & - & - & - \\
\hline $\mathrm{NaN}$ & - 2226 & $43 \% 4$ & 一 & - & - \\
\hline
\end{tabular}

The numbers in Columns III. and IV. express the amount of salt in grams per roo c.c. of liquid. The strength of the protein indicates the percentage in the mixture after addition of the salt solution.

Some of the salts in the above table, such as ammonium sulphate and potassium acetate, produce complete precipitation of all the proteins in the serum solution; others, such as sodium chloride, potassium chloride and sodium nitrate, do not produce complete precipitation of even the globulin fraction, when present to the extent of complete saturation.

Hofmeister investigated the relative influence of the acid and the metal of the salt on the power of precipitating proteins. His results are tabulated below. The numbers indicate the number of grams

1 For experimental methods, see the end of this section. 
in roo c.c. of solution when precipitation of globulin commences in a solution of egg-albumin, where the protein is present to the extent of 2 grams in roO c.c. after admixture with the salt solution.

\begin{tabular}{|c|c|c|c|c|c|}
\hline Sulphate & $\begin{array}{c}\text { Lithium. } \\
8 \cdot 6 \mathrm{I}\end{array}$ & $\begin{array}{c}\text { Sodium. } \\
\text { II } 39\end{array}$ & $\begin{array}{l}\text { Potassium. } \\
\text { No pp. }\end{array}$ & $\begin{array}{c}\text { Ammonium. } \\
\text { I3:39 }\end{array}$ & $\begin{array}{c}\text { Magnesium. } \\
15.93\end{array}$ \\
\hline hate & Not investigated & II.69 & ז3.99 & I6.57 & Slightly soluble \\
\hline Acetate & ", & 13.83 & $16 \cdot 38$ & No $\mathrm{pp}$. & No $\mathrm{pp}$. \\
\hline Citrate & , & 14.42 & $17 \cdot 07$ & $21 \cdot 99$ & Not investigated \\
\hline Tartrate & ," & $15 \cdot 11$ & I7.08 & 25.05 & $"$ \\
\hline Bicarbonate & $"$ & No pp. & $25 \cdot 37$ & Not investigated & 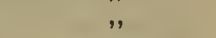 \\
\hline Chromate & " & $21 \cdot 22$ & 25.59 & No pp. & \\
\hline Chloride & - Changes pro & $S \quad 2 I \cdot 2 I$ & $26 \cdot 28$ & 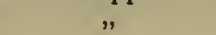 & No $\mathrm{pp}$. \\
\hline Nitrate & Not investigated & $46 \cdot 10$ & No pp. & N" & \\
\hline Chlorate & " & $58 \cdot 82$ & $"$ & Not investigated & Not investigated \\
\hline
\end{tabular}

It will be noticed from the above table that the capacity for precipitation depends on both the acid and the metal of a salt. The metals show a decreasing power of precipitation, passing from left to right of the table, whereas the acids show a decreasing power, passing from the top to the bottom. The same result is obvious when the numbers are expressed in terms of factors of normal solutions.

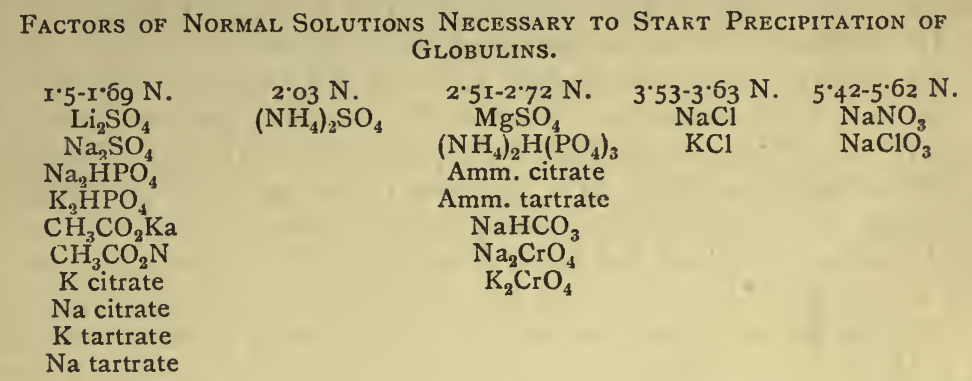

Some salts fail entirely to precipitate proteins owing to their small solubility in water. Thus, according to the above tables, on the assumption that the capacity for precipitation depends both on the acid and the metal, some concentration between I I. 39 and 13.39 per cent. of complete saturation by potassium sulphate should precipitate globulin. Potassium sulphate dissolves, however, only to the extent of $10^{\prime} 74$ parts in 100 parts of water at $15^{\circ}$. Similar remarks apply to potassium nitrate, potassium bicarbonate and potassium chlorate.

The application of the salt precipitation method to the separation of the products obtained by the digestion of proteins by proteoclastic ferments by Kühne and his pupils, Chittenden and Neumeister, has been mentioned already. They distinguished between "primary" proteoses, which are precipitable by sodium chloride or magnesium sulphate, "secondary" proteoses, which are precipitable in the filtrate from the primary proteoses by ammonium sulphate, and " peptones," which cannot be precipitated by salts. A revision of this work was undertaken in Hofmeister's laboratory by his pupils, Pick and Zunz, who used for the purpose of separation of fractions varying concentrations of one salt ( $c f$. Kauder's researches, p. Io). The former used ammonium sulphate, and the latter zinc sulphate, a salt which had been previously employed for protein precipitation by Bömer.

Pick, by half-saturation of Witte's peptone solution with ammonium sulphate, separated a so-called hetero- and proto-proteose fraction. From the filtrate containing the "secondary" proteose 
three further fractions were obtained, viz.: (i) "A " fraction, which is completely thrown out by 62 per cent. of complete saturation, and which is characterised by the relatively large amount of sulphur; (ii) "B" fraction, which is characterised by the intensity with which it gives the furfurol or Molisch-Udransky reaction (see p. 32), and which is precipitated by complete saturation in neutral solution ; and (iii) " $C$ " fraction, which is precipitated from the filtrate from " $B$ " by the addition of sulphuric acid solution saturated with ammonium sulphate. By repeated solution and reprecipitation, and treatment of the precipitates with alcohol, Pick succeeded in obtaining fractions which differed from one another, not only in their solubility and precipitability, but also in their elementary chemical composition.

Similar results have been obtained by Zunz with the use of zinc sulphate.

Another method of "salting out" has been suggested by Pinkus, who recommends the saturation of the solutions with anhydrous sodium sulphate at $37^{\circ} \mathrm{C}$.

The fractionation method, as employed by Pick and Zunz, has recently been subjected to a critical examination by Haslam.

It can hardly be contended that a process of the nature of fractional precipitation can readily produce a complete separation of fractions. Two sources of error are manifestly a priori conceivable, viz.: (i) any fraction produced by a particular degree of saturation is not absolutely insoluble in a solution of the strength in which it is precipitated ; (ii) a precipitate may carry down with it certain quantities of substance which belong to a subsequent fraction. In a separation of globulin from albumin, for example, the precipitate produced by half-saturation with ammonium sulphate will consist principally of globulin, but it will contain certain quantities of albumin; the filtrate, on the other hand, will contain mainly albumin, but it will not be entirely free from globulin, which is not absolutely insoluble in half-saturated ammonium sulphate solution. Two methods have been suggested by Haslam for testing the purity of a fraction.

I. Where it is sought to prove that a protein precipitate is free from the substances of the filtrate.

The precipitate is dissolved in water and the whole made up to a given volume; the amount of salt is added which is necessary to produce the requisite degree of saturation; the mixture after standing for twenty-four hours is filtered. If the filtrate contain no protein, or other substance from which the precipitate is to be freed, the requisite proof is furnished. If not, the organic nitrogen is estimated by Kjehldahl's method. The precipitate is then redissolved, the solution made up to the volume in which the original precipitation was performed, the same amount of salt is added, and the mixture is allowed to stand twenty-four hours, and finally filtered. The organic nitrogen in the filtrate is estimated. This process of precipitation at constant volume is repeated until the nitrogen in the filtrate is a constant, i.e., until only that amount of protein is present which is dissolved from the precipitate by the given volume of the solution of the degree of salt saturation in which the precipitation is carried out. This process of precipitation at constant volume must generally be repeated several times before a homogeneous precipitate is obtained. 
II. When the substance it is sought to purify is in the filtrate (e.g., an albumin contaminated with globulin).

In this case a process of fractional precipitation must be performed. By "fractional precipitation" a different process is implied to that suggested by Pick. The method employed by Haslam may be best understood by giving a concrete example of its mode of application, viz., the preparation of secondary or deutero-proteose. The primary proteoses in Witte's peptone are first separated by halfsaturation with ammonium sulphate; from the filtrate the secondary proteoses are precipitated by adding ammonium sulphate to complete saturation. This precipitate is then dissolved in water, and the solution half-saturated with the sulphate; a smaller quantity of primary proteose is precipitated than that obtained in the first precipitation; from the filtrate the secondary proteoses are precipitated again by complete saturation with the salt. These processes are repeated until half-saturation with the sulphate no longer produces a precipitate. Even now, the "secondary" proteose is not quite free from the primary. To the half-saturated solution, which should contain about 2 per cent. of proteoses, saturated salt solution is added until a small precipitate appears. Practice will enable the operator to judge how much substance it is best to precipitate at each "fractionation". The fraction is then filtered off, dissolved in water so as to make approximately a 2 per cent. solution, and to this is added an equal volume of saturated salt (i.e., ammonium sulphate) solution. A precipitate of primary proteoses (i.e., the substance which it is desired to separate off) will be produced; this is filtered off, and the filtrate is returned to the main solution. A second "fraction" is then taken from this by partial precipitation; this fraction is dissolved in water (to make 2 per cent. solution approximately), diluted with an equal volume of ammonium sulphate (another precipitation of primary proteoses) and the filtrate therefrom returned to the main solution. This process is repeated, a small quantity of primary proteose being removed each time from the solution, until a "fraction" no longer gives a precipitate on half-saturation. The main solution is then completely saturated with salt, and a precipitate thereby obtained which consists of a nearly pure deutero-proteose.

It will be seen from the above descriptions that the process of obtaining by salt precipitation a protein of constant composition is an extremely tedious one, and it is highly probable that most of the proteins obtained by earlier investigators by the method of fractional precipitation have been impure.

It may be remarked here that the methods employed by Haslam do not apply only to precipitation by salt solutions; fractional precipitation by alcohol of different strengths may be carried out in a quite analogous way.

Little detail has been given above concerning the fractions obtained by different observers from the products of digestion of proteins, such as Witte's peptone ; this subject, it is to be hoped, will be treated more fully in a monograph on digestion. Neither has anything been said on the physical processes involved in the method of "salting out"; this, again, is foreign to the scope of this article, and should be treated in the monograph which deals with the physics of colloidal solutions. 


\section{Method of Fractional Precipitation.}

The limits of precipitability may be determined in the following way. To 2 c.c. of a protein solution in a series of test-tubes are added 8 c.c. of liquid containing varying quantities of distilled water and saturated salt solution. The limits of incipient precipitation can be readily observed. [Pick found in working with Witte's peptone and ammonium sulphate solution that precipitation commenced when a mixture of $2^{\circ} 4$ c.c. saturated ammonium sulphate and 5.6 c.c. water were added to 2 c.c. of a peptone solution. Such a solution contains 24 per cent. of the salt necessary for complete saturation of the whole Io c.c. of liquid. In this case the initial limit of precipitation may be expressed by the number 24.] The contents of the other test-tubes containing a larger quantity of ammonium sulphate are examined by filtering off the precipitate and adding one or two drops of the salt solution to the filtrate; as soon as this addition no longer produces a precipitate, the higher limit of precipitation is reached. In dealing with a mixture, a second precipitation often commences with the addition of larger quantities of salts. This can be readily observed in the series of tubes which contain a higher concentration, and the point is noted when the addition of a drop of saturated salt solution to a filtrate produces a precipitate again. This point is the lower precipitation limit of a second fraction. The higher precipitation limit should also in this case be noted. A third fraction can also be obtained and its precipitation limits determined. [Pick showed that the first fraction, which commenced to fall out when the liquid was 24 per cent. saturated (see above), was completely precipitated with 42 per cent. saturation, i.e., the filtrate from the mixture 2 c.c. peptone, $4 \cdot 2$ c.c. ammonium sulphate solution, and 3.8 c.c. water just failed to give a precipitate when a drop of saturated salt solution was added; when, however, the 54 per cent. limit was reached, the filtrate just commenced to give a precipitate with a drop of saturated salt solution. By the method three fractions altogether were obtained, viz., the 24-42 per cent. fraction, the 54-62 per cent. fraction, and the 70-100 per cent. fraction.]

A pure protein gives reliable precipitation constants; attention must be called, however, to the criticisms of Haslam already outlined above on the application of the salting-out process to the separation of mixtures; as already noted, it is a tedious process to obtain a fraction of constant composition by the method.

Proteins, which are insoluble in water, but soluble in salt solutions, have also their precipitation constants. Osborne, in his work on the plant globulins, extracted his raw material with 10 per cent. ammonium sulphate solution; he then determined the precipitation limits by increasing the concentration of this solution. The constants were required to discover whether globulins derived from different plants were identical or not.

In determining the precipitation limits with animal liquids, such as serum, it must be remembered that these already contain salts ; in fact, the globulin can be separated from serum by dialysing these șalts away. 
As an example of a combined method of fractional precipitation by both alcohol and a salt, the following, for the separation of five constituents of Witte's peptone according to Haslam, may be quoted. To a 2 per cent. solution of Witte's peptone add an equal volume of alcohol and allow the mixture to stand overnight, or at least for some hours. Filter, collect the precipitate and swim it out on water. The insoluble portion is crude hetero-proteose and may be filtered off or obtained by decantation. The soluble portion contains $a$ proto- and $\boldsymbol{a}$-deutero-proteose; on half-saturation of the aqueous solution of the mixture with ammonium sulphate the former can be precipitated ; the latter comes down from the filtrate on complete saturation. The $\beta$-proto- and $\beta$-deutero-proteose remain in the first alcoholic filtrate. If the alcohol be evaporated off at a low temperature and the solution made up to its original volume, and the liquid thus obtained be half-saturated with ammonium sulphate, $\beta$-protoproteose is precipitated; by completely saturating the filtrate the $\beta$-deutero-proteose can be obtained. By performing the precipitations twice purer products can be obtained.

\section{Section II.-The Degree of Solubility of Proteins in SALT SOLUTIONS.}

In experiments on "salting out," the precipitation limits have almost always been determined in solutions containing but a small amount of protein; even when so much salt has been added that no further precipitation takes place, the solution may still contain a certain amount of protein, owing to the fact that the latter is not absolutely insoluble. But little work has been done so far in the determination of this degree of solubility; the most instructive is that, perhaps, of Osborne and Harris on the solubility of plant globulins in salts of various concentrations; in this case the results are of interest owing to the fact that the protein itself is insoluble in pure water. These investigators found that there were two classes of globulin solvents, viz.: (i) those in which a relatively considerable quantity of salt must be present before notable quantities of globulin commence to dissolve, and from which it is precipitated by dilution with much water, or by the addition of small quantities of strong acids, and (ii) those in which solution is brought about by low concentrations of salt from which the protein is not precipitated by dilution with water or by acids. The first class includes solutions of the salts of strong bases with strong acids, the second the solution of salts of weak bases.

The degree of solution is considerably influenced in the case of the globulin edestin by the presence of small quantities of acids and bases; this subject will, however, be discussed in greater detail later in considering the action of acids and bases on proteins. The behaviour of edestin towards acetate solutions is anomalous. Although it is insoluble in solutions of potassium, sodium and ammonium acetate, it is soluble in the acetates of barium, strontium, calcium and magnesium; the solubility in these acetates is in the order of their molecular weights. In solutions of silver, copper and lead acetates it is nearly as soluble as in solutions of free acids of corresponding concentration; the positive ion enters 
into combination with the edestin and no longer remains a free ion in solution. Acetates of zinc and mercury have no solvent action.

The solubility of serum-globulin in salt solutions has been investigated by $\mathrm{J}$. Mellanby. He found that the amount of globulin dissolved by a neutral salt depends upon the percentage of protein present and not upon the total quantity of salt. If a suspension of globulin be treated with a salt solution of given percentage, the amount of the protein dissolved will depend upon the strength of the suspension; more protein, for example, will be dissolved from a 5 per cent. suspension treated with a given quantity of salt solution than would be dissolved if the same quantity of a 2 per cent. suspension be treated in the same way. With regard to the solution capacity of various salts, he found that neutral salts with monovalent ions have the same efficiency; those composed of a monovalent positive ion and a divalent negative ion, or of a divalent positive and monovalent negative ion have also the same efficiency as one another. The salts of this latter class have a greater efficiency than those of the former. Mellanby concludes that the solution of globulins by neutral salts depends upon the forces exerted by the ions; that monovalent ions, whether negative or positive, are equally effective in producing solutions; that divalent ions, whether negative or positive, are also equally effective, but more effective than monovalent ions.

Another view as to the solution of globulins by salts is that a molecular compound of the type GBS ( $\mathrm{G}=$ globulin, $\mathrm{B}=$ base, $\mathrm{S}=$ acid) is formed, which is readily hydrolysed by water, with the liberation of insoluble globulin:-

$$
\mathrm{GBS}+\mathrm{H}_{2} \mathrm{O}=\mathrm{GHOH}+\mathrm{BS} \text {. }
$$

Such molecular compounds would be stable, therefore, only in presence of a large excess of the salt (Hardy).

In the present state of knowledge but little can be said with certainty as to the nature of the solution of those proteins in salt solutions, which are insoluble in pure water.

\section{Section III.-Solubility of Proteins in Organic Solvents.}

Some peptones and proteoses, as has been already mentioned, are soluble in alcohol. Certain proteins of plant origin are insoluble in water and absolute alcohol, but soluble in dilute alcohol. Bodies of this class have been subjected to an exhaustive examination chiefly by Ritthausen, and by Osborne and his co-workers. A typical protein of this class is the gliadin obtained from wheat. These bodies are generally soluble in some other organic solvents; zein, for example, the alcohol-soluble protein from maize, will dissolve in glacial acetic acid, in crystallised phenol on warming and in glycerol. In water and absolute alcohol it is perfectly insoluble; it is most soluble in alcohol of 85-95 per cent., and is but little soluble in alcohol of less than 50 per cent.

Mayer and Terroine have recently made a curious observation with reference to the alcohol solubility of proteins. They have shown that certain proteins which have been precipitated from a dialysed aqueous solution by alcohol acquire the property of redissolving in 
strengths of even $80-85$ per cent. on the addition of small quantities of salts. The albumin of horse serum can be redissolved under these circumstances by the addition of acids, bases or salts. If the horse serum be not dialysed before precipitation with alcohol, resolution in alcohol only takes place on the addition of acid or fairly strong alkalies. The dissolved serum-albumin does not lose its original properties. Egg-albumin, even when dialysed, acquires the property of being redissolved in alcohol wholly, by addition of bases, partially, by addition of acids, and not at all, by addition of salts. Nothing is known of the causes of these phenomena.

Many proteins are also soluble in urea solutions (Ramsden) and also in organic bases. This solubility is due probably to their acidic nature. Globulins, caseinogen, acid- and alkali-albumin and even heat-coagulated proteins dissolve in a saturated aqueous solution of pure urea. Dry gelatin dissolves at room temperature till a 40 per cent. solution is obtained. If the urea be removed by dialysis, the gelatin sets to a jelly again. The presence of urea, furthermore, prevents coagulation of solutions.

\section{Section IV.-Separation of Proteins From SOLution bY PRECIPITANTS OTHER THAN SALTS.}

Michaelis and Rona have recently suggested a new precipitant for proteins. When an alcoholic solution of gum-mastic is added to water an emulsion is formed, which, on addition of salts, is de-emulsified with the formation of a flocculent precipitate. If proteins be present in the emulsion colloidal particles will be obtained, consisting both of the mastic and the protein. If the former be in sufficient excess the whole of the latter will be carried down, when sufficient electrolyte (e.g., hydrochloric acid) has been added to de-emulsify the solution. The action is irreversible, in that the protein cannot be dissolved out from the precipitate by water. On treatment, however, with organic solvents, the mastic can be dissolved; if ether be used as a solvent hardly any nitrogenous matter goes into solution; with chloroform or alcohol, on the other hand, very appreciable quantities of nitrogenous matter are dissolved. The method has the disadvantage when applied to the separation of many proteins, in that the latter, when the attempt is made to recover them by means of ether, are rendered insoluble (coagulated), and thus cannot be obtained in their original form. The mastic can also partially precipitate proteose ; in the case of a commercial peptone obtained from fibrin, Rona and Michaelis found about 88 per cent. of the nitrogen in the filtrate, the remainder being precipitated by the mastic. They suggest the employment of the method for the separation of proteoses. In this case the mastic can be separated from the precipitated proteose without altering this substance. In solutions containing coagulable protein, such as serum, the method may be of use in estimating the non-protein constituents, such as urea, nitrogenous extractives and sugar, which are not carried down by the mastic precipitate.

This method is, so far, new. Owing to the irreversibility it does not seem as if it will be capable of such general application as the salt-precipitation method for the isolation of proteins; its chief use is for freeing solutions from proteins for the subsequent examination of 
substances not precipitated. Certain inorganic bodies which readily adsorb proteins have also been suggested for the removal of the latter from solution. These inorganic adsorbents have been investigated by Landsteiner and Uhlirz, who found that the most effective substances were precipitated silicic acid, meerschaum and iron oxide. Two grams of these powders, shaken with 20 c.c. of 0.25 per cent. solutions of proteins, can remove the whole of the latter from solution. The more readily a protein is precipitated by salts the more easily is it adsorbed by these non-crystalline powders.

\section{Method.}

It has already been stated that the mastic emulsion should be in large excess. In the case of liquids rich in protein, such as serum, a preliminary precipitation with alcohol can be carried out, or the mastic can be added in portions at a time. The following example will illustrate the method:-

One volume of serum is mixed with three volumes of alcohol. After separating the precipitate, one volume of a 50 per cent. solution of mastic in absolute alcohol is added and the mixture is then diluted with water till the alcohol does not form more than 30 per cent. of the total fluid. The liquid is then just acidified with acetic acid, and Io per cent. magnesium sulphate solution is added, IO-I 5 c.c. being employed for each litre of the solution. The precipitated mastic will then carry down the last traces of the protein remaining in solution.

\section{Section V.-Crystallisation of Proteins.}

Proteins, as colloidal bodies, were at one time thought to be incapable of existing in crystalline form. Later investigations have shown, however, that this is not the case, and the elaboration of methods for the crystallisation of certain substances of this class must be considered as a distinct advance in the chemical technique for the preparation of pure substances.

Crystalline bodies of a protein character were first observed in plants where they occur naturally. They were known as "aleurone" grains, and were first noticed in gluten by $\mathrm{Th}$. Hartig in 1850 . Their protein character was first demonstrated by Radlkofer in 1858 . They. occur in the seeds of a large number of plants, such as the pumpkin, in hemp seeds, in castor-oil seeds, and in Brazil nuts.

In some respects these aleurone grains differ from ordinary crystals. They can, for example, imbibe water and swell, during which process they lose to some extent their capacity for refracting light ; they retain, however, their original contours. The increase in size, as determined by accurate measurement by Schimper, is not the same in every axis. Another peculiarity is that aleurone grains will partially dissolve on treatment with glycerine, and an undissolved portion will be obtained which still retains the original crystalline contour, but which has nearly the same refractive index as water.

These peculiarities have caused the question to be raised as to whether these bodies are true crystals.

Similar naturally occurring protein crystals have also been described in animal organisms, notably in the intestinal epithelium of meal-worms and in the eggs of certain fish and amphibia. These 
latter bodies have been designated "yolk-platelets," and have formed the subject of an exhaustive investigation by Fremy and Valenciennes. They are possibly lecitho-proteins (Walther). Finally may be mentioned the hæmoglobin crystals, which are not observed normally in the animal body, but are occasionally found in preparations, and are sometimes formed as the result of post-mortem changes.

The first results in the artificial preparation of protein crystals were obtained by Maschke (1859), who evaporated a saturated solution of aleurone grains from Brazil nuts and obtained tabular, hexagonal crystals. In 1877 Schmiedeberg succeeded in recrystallising aleurone grains, which were also obtained from Brazil nuts. He dissolved the bodies in water at $30^{\circ}-35^{\circ}$ and precipitated them from this solution by mean; of a current of carbonic acid gas. The precipitate was then redissolved in water at $30^{\circ}-35^{\circ}$ with the addition of an excess of magnesia ; on allowing this solution to evaporate at the same temperature a certain number of large crystals were obtained, which Schmiedeberg regarded as the magnesium compound of the protein.

The preparation of crystalline proteins from plants formed, during the next two decades, the subject of a large number of memoirs, the chief of which are due to Ritthausen, and to Osborne and his coworkers. The plant globulins, to which class most of these crystalline substances belong, are, it must be recalled, insoluble in water but soluble in salt solutions; by allowing the proteins to separate from these solutions under suitable conditions the crystalline substances may be obtained. The following method of preparation of edestin, due to Osborne and modified by Leipziger, may serve as an example:-

One kilogram of hemp seed is ground, or pressed in an oil-press (a Buchner press can be employed when available). The remainder of the fat is then removed by extracting with light petroleum. When free from this solvent the seeds are digested at $60^{\circ}$ with I litre of 5 per cent. salt solution, and the mixture is kept continually stirred. The liquid is then filtered off from the residue through calico and allowed to cool. A precipitate forms and settles at the bottom of the vessel. The supernatant liquid is then decanted off and the precipitate washed by decantation with distilled water. It is then redissolved in 500 c.c. of 5 per cent. salt solution, and the solution filtered through a warm filter. On cooling beautiful crystals separate. These are washed with cold 5 per cent. salt solution, distilled water, alcohol and ether. Yield about Ioo grams.

In the cases of plant crystals, substances have been obtained in the laboratory in a crystalline form, which can exist in such form in nature.

A further great advance was made in 1889 , when Hofmeister described the preparation of a crystalline albumin from white of egg ; this was the first instance of the isolation in crystalline form of a protein which was not known to exist in this form in nature. Not long afterwards, Gürber and Michel succeeded in obtaining a crystalline albumin from horse serum. Hofmeister mixed egg-white with an equal volume of saturated ammonium sulphate; the globulin was thereby precipitated; on allowing the filtrate from this to evaporate slowly in an open basin, the albumin separated in the form of so-called globulites or spherolites. These were redissolved in dilute ammonium sulphate, and the solution was allowed to slowly evaporate 
as before. On a second recrystallisation, needles were obtained mixed with the spherolites; on repeating the crystallisation a sufficient number of times, a product consisting entirely of needles was obtained.

The original method of Hofmeister has been modified in various ways. It has been shown that ammonium sulphate solution containing protein becomes alkaline on standing; Hopkins and Pinkus have shown that the addition of acid facilitates very considerably the process of crystallisation. The method as modified by these investigators is the one now in general use and is carried out in the following way :-

Egg-white is beaten to a froth (to break up the membranes) with exactly its own bulk of ammonium sulphate solution. The mixture, after standing overnight, or at least for a few hours, is filtered from the precipitated protein. The filtrate is now measured. Ten per cent. acetic acid (glacial acetic acid diluted to ten times its bulk) is then very gradually added from a burette, until a well-marked precipitate forms-a precipitate sufficient to make the mixture actually milky in appearance, and not a mere opalescence for which liberated gas bubbles might be mistaken. The actual amount of acid required to produce such a precipitate will vary (chiefly because of the varying loss of ammonia which occurs when the liquid has previously stood in open vessels). The point corresponds roughly to an incipient acidity of the liquid towards litmus, but the formation of the precipitate forms of itself the best indicator. This stage being reached, a measured quantity of the acid is now added, over and above that required to produce the first precipitate, I c.c. being added for each Ioo c.c. of the filtered mixture as originally measured. The whole contains, therefore, approximately I part per thousand of free acid. The bulky precipitate thus produced is at first amorphous, and if the mixture be occasionally shaken the amorphous precipitate will give place to crystals within four or five hours. To obtain the full yield, however, the material should stand for twenty-four hours. The product thus obtained is already nearly pure. On recrystallising once more from ammonium sulphate (dissolving in water, and then carefully adding half-saturated ammonium sulphate containing acetic acid in the proportion of I per thousand, till a permanent precipitate forms, and then about 2 c.c. of ammonium sulphate per litre in excess of this) a perfectly pure preparation is obtained.

Considerable difficulty has been experienced in obtaining serumalbumin in a crystalline form. Formerly it was obtained almost entirely from the blood of the horse, but even here the attempt to obtain a crystalline preparation does not always meet with success. In these cases Gürber's method was employed. The serum was mixed with an equal volume of concentrated ammonium sulphate solution; then, to the filtrate from the precipitated globulin, ammonium sulphate solution was added until there was an incipient turbidity; on allowing the mixture to stand the serum-albumin crystals separated. Inagaki has recently shown that crystalline serum-albumin can be readily obtained by the Hopkins and Pinkus' method, i.e., in the presence of free acid. Crystallisation also takes place more readily at a somewhat higher temperature $\left(35^{\circ}-40^{\circ}\right)$. The 
crystals obtained are, according to Inagaki, compounds of protein with sulphuric acid.

It is possible that the other crystalline proteins are also compounds with acids. This subject will be reconsidered later, in discussing the action of acids and bases on proteins.

A special case of protein crystallisation is that of hæmoglobin. This is a conjugated protein, i.e., it is a compound of a protein and a chromatogenic group, and its power of crystallisation depends on the presence of this group. Crystals can be obtained by the following method, due chiefly to Zinoffsky and modified by Abderhalden.

The paste of red blood corpuscles (from a horse), after separating from the serum and washing, is mixed with twice its volume of water and the mixture is then warmed to $35^{\circ}$. The corpuscles are by this treatment laked. A very small known quantity of ammonia is then added to dissolve the stromata, and then hydrochloric acid in very dilute solution is added in such quantity as to exactly neutralise the ammonia. The mixture is then cooled to $0^{\circ}$, and onequarter the volume of absolute alcohol is added. The whole is kept on ice, and crystals slowly separate out, and settle at the bottom of the vessel. The supernatant liquid is then poured off, and the crystals are washed by decantation with a mixture of one part alcohol and four parts of water previously cooled to $0^{\circ}$. They can be recrystallised by dissolving the crystalline paste in twice its volume of water at $35^{\circ}$, then cooling to $0^{\circ}$, adding one-quarter the-volume of alcohol, and allowing the crystals to form slowly at a low temperature.

It must be remembered that only a relatively small number of proteins have as yet been obtained in crystalline form, and recrystallisation as a mode of purification has, so far, not obtained a very wide application. It is not known whether any chemical change takes place during the process, and there is a certain amount of evidence that in the case of crystallised egg-albumin, for instance, the crystallised product is different from the original protein existing in the egg-white (see "gold number" of crystallised and non-crystallised egg-albumin, p. 27).

\section{Section VI.-The Temperature of Heat Coagulation of Protein Solutions.}

In I 854 Kühne noticed that there were two proteins present in muscle-plasma which differed in the temperature of heat coagulation, and since that time the coagulation point has been regarded as an important factor for distinguishing between proteins, and the process of separating proteins in mixtures by means of a fractional heat coagulation has been repeatedly employed. In this operation a solution of the mixture is heated to a definite temperature until a coagulum is produced; this is filtered off, and the filtrate heated to a still higher temperature, when there is the formation of another coagulum; further fractions can be taken until no more coagulable protein remains in solution. Thus Halliburton, by such a process, separated in 1887 several proteins from muscle-plasma, which he designated as follows : paramyosinogen, coagulating at $47^{\circ}$; myosinogen, coagulating at $56^{\circ}$; myoglobin, coagulating at $63^{\circ}$; all of which can be precipitated from solution on saturation with sodium chloride 
and magnesium sulphate ; in addition to these an albumin coagulating at $73^{\circ}$ was obtained, which cannot be so precipitated.

Other coagulation points were determined by Frédericq.

It is not in the least probable that such a process as fractional coagulation can lead to a complete separation of a mixture of proteins; it is, moreover, irreversible, and in this respect cannot have such a general application as, e.g., the separation by means of salt precipitation.

It remains to be considered, however, how far the coagulation temperature may be regarded as a constant characteristic of any individual protein. (NOTE.-All proteins do not form heat-coagulable solutions.) It was long ago observed that the reaction of the liquid and the presence of neutral salts exercised a marked influence on the coagulation temperature. In the case of natural fluids, such as muscle-plasma, serum, etc., which contain salts, it was noticed that the coagulation took place more readily in a slightly acid solution; the presence of larger quantities of acids, however, inhibited the coagulation, owing to the formation of acid albumin. In the experiments of Halliburton, already referred to, the fractional coagulation was carried out with solutions having a certain definite acidity.

The influence of salts was recognised by Aronstein (1874), who showed that a solution of egg-white, from which inorganic matter had been almost completely removed by dialysis, lost its coagulability. Subsequent researches were undertaken by Alexander Schmidt and Heynsius, and it was found that the protein solutions of Aronstein still contained alkali, although the neutral salts had dialysed away. Heynsius made the further observation that by very long-continued dialysis, by means of which nearly all the alkali is removed, a solution is obtained which recovers its coagulability; the coagulation in this solution is inhibited, however, by the presence of minute quantities of acids and alkalis. Similar results were obtained by Winogradoff and Haas.

The capacity for coagulation of a solution depends, therefore, both on its reaction and the quantity of neutral salts present; the smaller the quantity of the latter, the smaller the amount of alkali necessary to inhibit coagulation.

Careful quantitative studies on the influence of salts on the temperature of coagulation have been undertaken by Starke and by Pauli, the latter of whom has endeavoured by his researches to throw some light on the chemico-physical process involved in the coagulation of colloids.

Starke determined the amount of various neutral salts that were necessary to restore the coagulability of a protein solution, which had been deprived of this property by dialysis. He found that in the case of the salts of alkaline earths and magnesium, a few milligrams per Io0 c.c. of solution sufficed, whereas with the alkaline salts I gram per 100 c.c. was required. Starke also investigated the influence of varying quantities of different salts on the temperature of coagulation. This question was the subject of a more exhaustive investigation by Pauli. The following table, which is one out of a large number to be found in Pauli's earlier paper, illustrates the influence of varying quantities of different salts on a certain solution of egg-white. In all cases 2 c.c. of the egg-white solution were 
diluted to ro c.c.; the numbers in the first horizontal line indicate the number of cubic centimetres of normal solutions of various salts contained in the ro c.c.

Influence of Various Chlorides on Coagulation Point.

\begin{tabular}{|c|c|c|c|c|c|c|c|c|c|c|c|c|}
\hline c.c. & 0.5 & ro & $1 \cdot 5$ & 20 & $2 \cdot 5$ & 3.0 & 3.5 & $4^{\circ} 0$ & 4.5 & $5 \circ$ & $5 \cdot 5$ & 6.0 \\
\hline $\mathrm{NH}_{4}$ & & $58 \cdot 2$ & $59^{\circ} \mathrm{I}$ & $60^{\circ} \circ$ & $60 \cdot 3$ & $60 \cdot 5$ & $60 \cdot 7$ & $6 r \cdot 0$ & - & - & - & - \\
\hline $\mathrm{K}$ & 60.9 & $6 \mathrm{I} \cdot 6$ & $6 \mathrm{r} \cdot 9$ & $62 \cdot 2$ & - & - & - & - & - & - & - & - \\
\hline $\mathrm{Na}$ & $6 r \cdot 8$ & 62.6 & 63.4 & $64 \cdot 2$ & 64.5 & $63 \cdot 6$ & $62 \cdot 4$ & $60^{\circ}$ & - & - & - & - \\
\hline $\mathrm{Li}$ & $62 \cdot 0$ & $64 \cdot 6$ & $68 \cdot 2$ & $7 \times 3$ & $72 \cdot 6$ & $73^{\circ} \cdot 2$ & $72 \cdot 6$ & $7 I^{\circ} \cdot 7$ & $70 \cdot 8$ & $68 \cdot 0$ & $62 \cdot 8$ & $59 \cdot 8$ \\
\hline $\mathrm{Ba}$ & $60 \cdot 9$ & $67 \cdot 8$ & $7 \mathrm{I}^{\circ} 5$ & $7 \times \cdot 5$ & - & & - & - & - & - & - & - \\
\hline $\mathrm{Mg}$ & 60.9 & $70 \cdot 8$ & $75^{\circ}$ & $75^{\circ} 2$ & $76 \cdot 2$ & $77^{\circ} 8$ & $78 \cdot 2$ & $78 \cdot 8$ & - & - & - & - \\
\hline
\end{tabular}

It will be seen from the above table that the increase in the quantity of salt raises the coagulation temperature up to a certain point, after which, in some cases, further additions of salts cause no increase, and in other cases even a diminution.

It is not necessary here to discuss the physical meaning of such numbers as these; enough has been said to indicate that the coagulation temperature is a constant which is markedly influenced by a variety of factors. The chief ones are, as Starke pointed out : (i) the reaction of the solution, (ii) the amount of neutral salts present, in a minor degree (iii) the concentration of the protein, and (iv) the rate at which the solution is heated. Far less reliance can be placed on coagulation temperatures as a constant for identification of proteins than on such a constant as the melting point of a crystalline substance, especially when it is remembered that it is often difficult to exactly regulate the amount of salt, acid or alkali present in any given solution. ${ }^{1}$

\section{Method (according to Pauli).}

The liquid to be tested is placed in a test-tube, provided with a stirrer, and in it is immersed a thermometer graduated in $\frac{1}{10}$ or $\frac{2}{10}$ degrees. The test-tube is immersed in water in a beaker of I litre capacity, which is likewise provided with a thermometer and stirrer. The whole is slowly heated with a small burner, the liquid in both test-tube and beaker being carefully stirred, so that both vessels attain the same temperature.- When there is a black background and the apparatus receives light from two sides the smallest turbidity is readily recognised. The time a solution takes to coagulate should also be noticed; this factor bears no relation to the coagulation temperature.

1 Wolfgang Ostwald has recently represented the relation between the amount of salt present and the coagulation temperature by the following equation $-\frac{I}{t}=k c^{m}$ where $t=$ temperature, $c$ salt concentration, and $k$ and $m$ are constants. He draws attention to the similarity between this and an adsorption equation. Pauli, in some very recent work, comes to the conclusion that the coagulation point is influenced by the condensation of ions on the surface of the colloidal particles. 


\section{THE GENERAL CHARACTERS OF THE PROTEINS}

TABLE.

Coagulation Temperatures of some of the Principal Proteins.

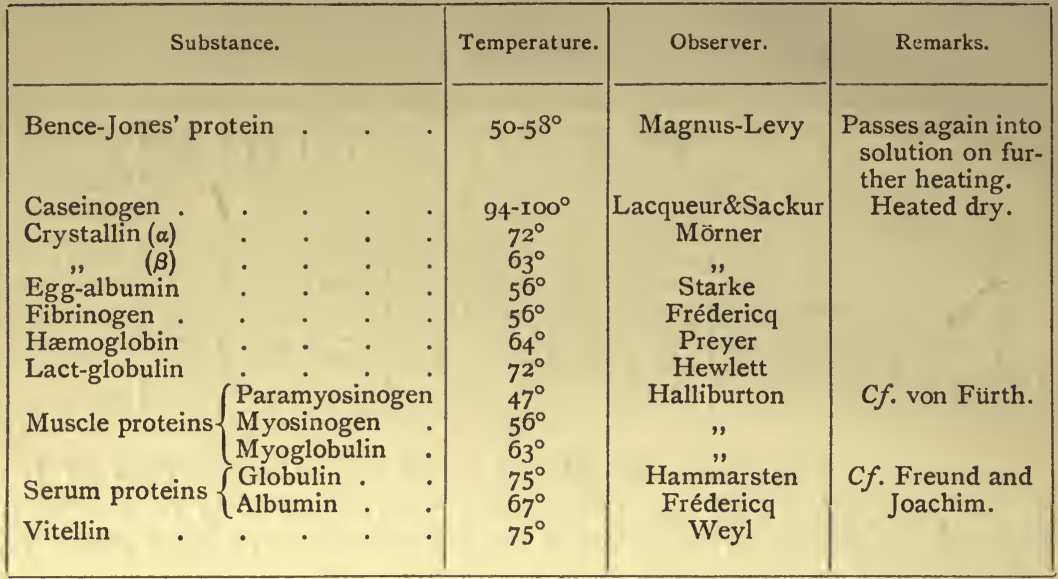

\section{Section VII.-Optical Rotation of Protein Solutions.}

Solutions of proteins are optically active. The rotations, like those of the amino-acids, vary according to the amount of acid present in solution. The number of reliable determinations of the optical rotation of protein solutions is small. Of special interest are those of the vegetable proteins, in which the rotation was measured under as nearly as possible identical conditions. Some of the chief determinations are given in the following table:-

Protein.

Animal proteins :-

Egg-albumin

Hæmoglobin

Globin

Nucleo-proteins

Crystallin ( $\alpha$-variety)

" $(\beta$-variety)

Plant proteins :-

Edestin (Hemp-seed)

Globulin (Flax-seed)

". (Squash-seed)

Excelsin (Brazil-nut)

Amandin (Almond)

Corylin (Filbert)

Globulin (English-walnut)

". (Black-walnut)

Phaseolin (Kidney-bean)

Legumin (Horse-bean)

$Z$ ein (Maize)

Gliadin (Wheat)
Rotation.

$[\alpha]_{D}-30^{\circ} 70$

$\left.[\alpha]_{c}+10 \cdot 4\right\}$

$\left.[a]_{c}-54^{\cdot 2}\right\}$

Dextrorotatory

$[\alpha]_{D}-46 \cdot 9$

$[a]_{D}-43 \cdot 3$

$[\alpha]_{\mathrm{D}}$

$-4 \mathrm{I} \cdot 3$

$-43.53$

$-3^{8 \cdot 73}$

$-42.94$

$-56 \cdot 44$

$-43^{\circ} 09$

$-45^{\circ} 2 \mathrm{I}$

$-44^{\circ} 43$

$-4 r^{\circ} \cdot 4$

$-44^{\circ} \circ 9$

$-28 \cdot 20$

$-92 \cdot 28$

\section{Observer.}

Hopkins and Willcock.

Gamgee and Croft Hill.

Gamgee and Jones.

Osborne.

",
",
",
",
",
",

\section{Section VIII.-Molecular Weight Determinations BY CRYOSCOPIC METHODS.}

(A) Depression of Freezing Point.

Several data are to be found in the literature referring to the depression of the freezing point of water caused by the solution of 
proteins. The determinations were made with a view to the estimation of molecular weights. The data arrived at by this method are, however, of little value. In the first place it is, as has been repeatedly stated, extremely difficult to free proteins from the last traces of inorganic substances; very small contaminations of such substances with low molecular weight would cause relatively very large errors in the determination of the molecular weight of such complex substances as the proteins. In the second place, from the direct determinations of osmotic pressures, discussed in greater detail below, the depression in the freezing point of a salt-free protein should be so small as to be well within the limits of experimental errors. Moore has calculated that ${ }^{\circ} \mathrm{OOI}{ }^{\circ} \mathrm{C}$. should correspond to an osmotic pressure of $9 \mathrm{~mm}$. of mercury. The smallest depression that can be measured by a Beckmann thermometer is $005^{\circ} \mathrm{C}$., which corresponds to an osmotic pressure of $45 \mathrm{~mm}$. As, in practice, pressures of this order have to be measured in the investigation of proteins, when estimating osmotic pressures directly, it is obvious that but little value can be attached to determinations of freezingpoint depressions. Nevertheless, some of those determinations made with peptones and other degradation products are of interest, as substances of much lower molecular weight than the proteins from which they have been derived are here being dealt with. It must be remembered, however, that these peptones are not pure bodies. A few data from the literature, with these reservations, are given below :-

\begin{tabular}{|c|c|c|}
\hline $\begin{array}{l}\text { Substance. } \\
\text { Egg-albumin }\end{array}$ & $\begin{array}{l}\text { Molecular } \\
\text { Weight. } \\
\text { I4,270 }\end{array}$ & $\begin{array}{l}\text { Observer. } \\
\text { Sabanejew and Alexandrow. }\end{array}$ \\
\hline Protalbumose & $2467-2$ & Sabanejew. \\
\hline Deutero-albumose & 3200 & \\
\hline Albumose & 2400 & Bugarsky and Liebermann. \\
\hline Peptone (commercial) & I5O4-I754 & Sabanejew. \\
\hline Propeptone & I2OI-I 215 & Paal. \\
\hline Antipropeptone (albumose) & $776-823$ & ", \\
\hline $\begin{array}{l}\text { Gelatin } \\
\text { Peptone (Merck) }\end{array}$ & $878-960$ & C"'mician \\
\hline Glutin-peptone hydrochloride & $\begin{array}{l}529-555 \\
278-704\end{array}$ & $\begin{array}{l}\text { Cramician an } \\
\text { Paal. ", }\end{array}$ \\
\hline
\end{tabular}

\section{(B) The Direct Determination of Osmotic Pressure.}

Considerable controversy has arisen as to whether colloids exert any osmotic pressure in solution. Several investigations on this subject are, however, recorded in the literature. Starling, in the course of some researches on the function of the glomeruli of the kidney, measured the osmotic pressure exerted by a serum solution of known protein content. A vessel was used the walls of which were permeable to the salts but not to the proteins contained in the serum ; for this purpose they were constructed of peritoneal membrane of calf previously soaked in gelatin. On the other side of the membrane was placed a fluid which possessed approximately the same salt contents as the serum; this was generally prepared by freeing the serum experimented with from its protein by pressing it through gelatin filters under a pressure of 30-40 atmospheres. By having on one side of the membrane natural serum, and on the other serum deprived of proteins by filtration, and by connecting the protein containing liquid with a manometer, the osmotic pressure 
due to the serum protein alone could be directly estimated, and the errors due to the presence of salts thereby eliminated.

Moore has modified this method for estimating the osmotic pressure of colloids. He employs a special form of osmometer, consisting of two similar platinised capsules each of about 20 c.c. capacity, each with a flange. By a special arrangement of rubber bands these capsules can be screwed together. When in this position they are separated by a thick platinum grid which passes between the flanges and supports a parchment membrane. One capsule containing the colloid is connected with the manometer, whilst the other contains a liquid of which the non-colloid contents are approximately isotonic with those of the solution containing the colloid. In this way the errors due to the presence of the non-colloidal, dialysable substances, etc., are readily eliminated.

Various estimations of osmotic pressure have been carried out with the use of apparatus of this character, chiefly by Weymouth Reid, who used the Starling form of osmometer, and by Moore and Parker, and Moore and Roaf.

Reid showed that proteins that have been well washed have practically no osmotic pressure. He attributes the osmotic pressure of protein solutions recorded by other observers to the adsorbed inorganic substances. He found, however, for purified dogs' hæmoglobin an osmotic pressure varying from $3.63 .435 \mathrm{~mm}$. $\mathrm{Hg}$ per I per cent. concentration. This is in accord with an observation of Gamgee (published in abstract, Proc. R. S., I 902, 70, 79) that hæmoglobin possesses conductivity and is therefore in true solution.

Moore and his co-workers observed quite appreciable pressure with different proteins, which varied with the salt contents of the solution. Moore maintains, in opposition to Reid, that the proteins exert a definite osmotic pressure, but that their state of aggregation varies in solutions containing different quantities of salt; he conceives that by repeated reprecipitation, washing, etc., the aggregates become so large that they exert no osmotic pressure.

From the above short summary it is obvious that cryoscopic methods, at any rate in the present state of our knowledge of colloids, can bear but little value in fixing the character of individual proteins.

\section{Section IX.-The Electrolytic Conductivity of Protein SOLUTIONS.}

The difficulty of obtaining protein solutions free from electrolytes with relatively high conductivity must be taken into account again when measuring the electrolytic conductivity of protein solutions.

The method has been employed in a large number of cases, as an adjunct to chemical methods, e.g., in determining the capacity of proteins to form salts with acids or bases, in determining the dissociation constants of such salts, and also in investigating the rate of hydrolysis of proteins by acids or enzymes. It will be necessary to refer to the conductivity of protein solutions again later when discussing the action of alkalies and bases (p. 39). 


\section{Section X.-The “ Gold Number ".}

Zsigmondy has shown that colloids possess the property of inhibiting the transformation of bright red colloidal gold solutions into the non-colloidal form, a change which can be brought about by the addition of salts. The quantity of substance necessary to inhibit this transformation varies greatly with different classes of colloids, and is characteristic for each individual. Zsigmondy proposes, therefore, to regard this quantity as a definite factor for the identification of individual colloids. The "gold number" he defines as "the number of milligrams of a colloid which are just insufficient to prevent Io c.c. of a bright red gold solution, prepared under certain specified conditions, from changing into violet; or nuances of violet immediately, or shortly after the addition of I c.c. of a Io per cent. salt solution".

He divides the colloids into four classes, viz. :-

Class I. Colloids with the gold number $0^{\circ} 005$ to $0^{\circ} \mathrm{I}$. This includes gelatin, caseinogen, isinglass, animal glue.

Class II. Colloids with gold number $0^{\prime}$ I to IO, including crystalline egg-albumin, gum-arabic, tragacanth.

Class III. Colloids with gold number Io to 500, including dextrin, potato starch.

Class IV. Colloids which are inactive, including silicic acid, soluble glass and mucin.

In the following table are given the gold numbers of certain characteristic proteins :-

\section{TABLE.}

\begin{tabular}{|c|c|}
\hline $\begin{array}{l}\text { Substance. } \\
\text { Gelatin }\end{array}$ & Gold Number. \\
\hline Russian glue & $\begin{array}{l}0.005-0.01 \\
0.005-01 \\
0\end{array}$ \\
\hline Isinglass & $\begin{array}{ll}0.01-0.02 \\
0.05\end{array}$ \\
\hline Caseinogen & 0.01 \\
\hline Glycoprotein & $0 \cdot 05-0 \cdot \mathrm{I}$ \\
\hline Deutero-albumose & $\infty$ \\
\hline Egg-globulin & $0.02-0.05$ \\
\hline Ovomucoid & $0 \cdot 04-0 \cdot 08$ \\
\hline Crystallised egg-albumin & $2-8$ \\
\hline $\begin{array}{l}\text { Amorphous } \\
\text { (After separation }\end{array}$ & $\begin{array}{l}\text { o.03-0॰06 } \\
\text { line.) }\end{array}$ \\
\hline $\begin{array}{l}\text { Merck's albumin } \\
\text { Fresh egg-white }\end{array}$ & $\begin{array}{l}0 \cdot 1-0 \cdot 3 \\
0.08-0.15\end{array}$ \\
\hline
\end{tabular}

It is of interest to note in the above table the high value for crystallised egg-albumin.

\section{Method.}

Preparation of the Gold Solution.-One hundred and twenty c.c. of water are distilled through a silver condensing tube into a beaker of Jena glass of 300-500 c.c. capacity. They are then heated, and during the warming 2.5 c.c. of a 0.6 per cent. solution of hydrogen gold chloride and $3-3.5$ c.c. of a solution of the purest potassium carbonate ( 0.18 normal) are added. After boiling, and whilst the mixture is still hot, $3-5$ c.c. of a dilute solution of formaldehyde $(0 \cdot 3$ c.c. commercial formalin in 100 c.c. $\mathrm{H}_{2} \mathrm{O}$ ) are added. Only Jena glass rods should be used for stirring. After a short time a bright red 
colour is developed. A solution thus prepared can be kept for a long time without changing.

Determination of the "Gold Number".-Small quantities of the colloid solution under investigation are introduced into a series of 50 c.c. beakers. The colloid should be measured out from a 0.2 c.c. pipette graduated in thousandths of a cubic centimetre. The quantities generally used are $0^{\circ} 005,0^{\circ} 01,0^{\circ} 02,0.05$, up to 0.5 c.c. Larger quantities of solution are to be avoided. Five c.c. of the gold solution are then introduced into each beaker, and the mixture is then rapidly stirred. After three to five minutes 0.5 c.c. of sodium chloride solution (I00 grams $\mathrm{NaCl}$ to 900 c.c. water) is introduced into each beaker. By this method a higher limit can be observed in which no change takes place, and a lower limit in which the red solution is converted into violet. In this way the limits are determined. The number of milligrams of colloid in each of these limits, multiplied by 2 , gives the interval which is designated the "gold number". This factor is the one generally determined (see table above).

\section{Section Xi.-The Fractional Filtration of Proteins.}

In 1896 C. J. Martin described a gelatin filter, through which, under pressure of 40-50 atmospheres, water and simpler substances, such as sugar and salts, could be made to pass, whereas more complex colloidal bodies, such as the proteins, were held back. The apparatus employed consisted essentially of a Pasteur-Chamberland filter candle, which acted as a support for a membrane of gelatin or silicic acid. This was mounted in a gun-metal filter case, which was connected with a steel gas cylinder containing air under the requisite pressure. The liquid to be filtered was introduced into the filter case, which was then connected with the compressed air cylinder. The water and simple bodies commenced to filter through as soon as the requisite plus-pressure was attained. This process of filtering served as a means of concentrating protein solutions and at the same time freeing them from contamination with simpler substances.

It has since been employed in a limited number of cases for obtaining some information as to the relative sizes of molecular aggregates in protein solutions. Thus, for example, W. A. Osborne has shown that the sodium salt of caseinogen will pass through a Martin filter, whereas the salt of the dibasic calcium, with approximately double the molecular weight, is held back. Craw has also employed this filter for the separation of toxins and antitoxins.

The principle involved in the Martin filter has recently been extended by Bechhold, who has devised a method of fractional filtration. Instead of employing a filter candle for impregnation with the filtering membrane he uses filter paper. This is soaked in the impregnating membrane (either acetic acid solution of collodium or an aqueous solution of gelatin) in vacuo in a specially devised apparatus. In this way a relatively thin filter with a large surface can be obtained. This is introduced into a suitably constructed filter funnel, in which it is supported on a nickel gauze; the funnel is inserted in a metallic cylinder, which can be connected either with compressed air or a force pump, so as to produce a plus-pressure on one side of the filter; a stirrer can also, if necessary, be inserted so 
that the surface of the filtering liquid in contact with the membrane can be continually changed. With this apparatus comparatively small plus-pressures only are necessary (from $\frac{1}{2}$ to 5 atmospheres).

By employing impregnating membranes of different concentrations Bechhold has succeeded in devising a method of differential filtration. Thus, for example, a filter paper impregnated with 3 per cent. gelatin, when tested with a I per cent. hæmoglobin, allowed appreciable quantities of the solute to pass; a similar filter impregnated with 4 per cent. gelatin was not permeable to hæmoglobin.

The more concentrated the impregnating solution the higher the plus-pressure necessary for filtration.

The filters made from more concentrated solutions have necessarily smaller pores; such filters will allow the passage only of substances in a state of comparatively simple aggregation; they can in this way be separated from the substances in which the state of aggregation is more complex. An interesting example of the method of employment of the filter is afforded by Bechhold in his description of the attempt to separate the constituents of Witte's peptone. Pick (see p. 14) has described the following fractions obtained with ammonium sulphate: Protalbumose (24-42 per cent. saturation), deuteroalbumose A (54-62 per cent.), deutero-albumose B (70-95 per cent.), deutero-albumose $\mathrm{C}$ (I00 per cent. + acid). A clear 5 per cent. solution of Witte's peptone solution, which gave a precipitate on 23 per cent. saturation, was submitted to filtration under I atmosphere plus-pressure through a 3 per cent. gelatin filter; a similar filter impregnated with $2^{\circ} 5$ per cent. gelatin was just not permeable to hæmoglobin. ${ }^{1}$ The residue on the filter was twice diluted with water and twice subjected to filtration with a similar filter. Precipitation in the filtrate commenced only when the saturation with ammonium sulphate reached 34 per cent., whereas the residue on the filter commenced to precipitate when the liquid was only 23 per cent. saturated; hence a separation into two fractions, viz., one precipitable at 34 per cent. saturation and one at 23 per cent. Other experiments of similar nature gave analogous results. They are summarised below :-

Fraction and Precipitation Limits,

Protalbumose (24-42 per cent.)

Deutero-albumoses $\mathrm{A}+\mathrm{B}$ (54-95 per cent.)

Deutero-albumose C (roo per cent. + acid)

cent. + acid)

Fractional filtration gives results, therefore, which are analogous to those obtained by fractional precipitation with salts and may serve as a valuable additional adjunct to this process. Here, again, however, complete separations are not to be expected; for neither the size of the aggregates in the solution to be filtered, nor the size of the filter pores, are of uniform size, as Bechhold has experimentally demonstrated. The method is still new, and promises to be a valuable addition to the technique for dealing with proteins. It might prove of great utility in conjunction with a tedious fractional precipitation method, such as that employed by Haslam.

1 One per cent. hæmoglobin was used as a test solution for filter membranes; the minimum concentration necessary to produce a filter not permeable to hæmoglobin in this solution was determined. To express this the formula 3 per cent. ( $\mathrm{H}_{2} .5$ per cent.) is employed. 
PART II.

\section{THE GENERAL CHEMICAL CHARACTERS OF THE PROTEINS.}

\section{Section XII.-The Qualitative Reactions of the PROTEINS.}

Proteins may be precipitated from solutions by the following reagents:-

I. By various mineral acids. Nitric acid is very often employed. If allowed to flow into a protein solution a white ring forms at the junction of the acid and the solution. This delicate reaction is generally known as Heller's test.

Metaphosphoric acid is a precipitant of the proteins, but not the ortho- or pyro-acids.

II. Ferrocyanic acid is a good precipitant. A mixture of potassium ferrocyanide and acetic acid is generally employed.

III. The salts of the heavy metals precipitate proteins. This reaction will be discussed in greater detail later.

IV. The ordinary alkaloidal reagents precipitate proteins, e.g., phosphotungstic acid, phosphomolybdic acid, potassium mercuric iodide, potassium bismuth iodide, tannic acid, picric acid. These reagents should be added to the slightly acidified solution.

V. Trichloracetic and sulphonylsalicylic acids are good precipitants.

VI. Also uranyl acetate. The precipitate thus produced is soluble in acids.

VII. Nucleic acid and protamines.

The following are the chief colour reactions for proteins. Not every protein gives a positive result when treated with the reagents, as the various colours are due to certain specific groups contained in the molecule, which are not common to all proteins. Nevertheless, every protein will give positive reactions in a large number of the tests.

I. Biuret Reaction.-The protein is first treated with sodium hydroxide solution, and then copper sulphate in very dilute solution is added drop by drop; a reddish violet to violet-blue colour will be produced. This is due, according to Schiff, to the presence of the following groups :-<smiles>NC(=O)CNC(N)=O</smiles><smiles>NC(=O)CC(N)=O</smiles><smiles>NC(=O)OC(N)=O</smiles><smiles>CC(C)(C)NC(=O)C(C)(C)N</smiles>

II. The Xanthoproteic Reaction.-Proteins give on boiling with strong nitric acid yellow flakes or a yellow solution, which, on 
making alkaline, becomes orange yellow. This is probably due to the presence of a radical containing the benzene ring.

III. Millon's Reagent. - This consists of a solution of mercury in nitric acid, which contains nitrous acid. This reaction is due to the presence of a tyrosine group.

IV. Colour Reactions due to the Presence of the Tryptophane Group:-

(a) The chief of these is the Hopkins and Cole modification of the so-called Adamkiewicz reaction. As originally proposed by Adamkiewicz, the reaction consisted in treating the protein solution with one volume of concentrated sulphuric acid and two volumes of glacial acetic acid; a reddish violet colour was thereby produced. Hopkins and Cole have shown that this reaction is due to the presence in the acetic acid of glyoxylic acid, produced by the oxidation of the former body, a process which readily takes place on its exposure to sunlight. They now use a solution of glyoxylic acid itself, which is produced by the reducing action of sodium amalgam on a solution of oxalic acid.

(b) Reichl's Reaction.-On mixing a protein with an alcoholic solution of benzaldehyde and adding dilute sulphuric acid (one volume of acid to one volume of water) and ferric sulphate a blue coloration is produced.

(c) Rhode's Reaction.-A weak solution of dimethylaminobenzaldehyde is mixed with the protein solution, and concentrated sulphuric acid is allowed to flow into the mixture. A reddish violet colour is thereby produced which changes to dark violet.

(d) Liebermann's Reaction.-When a protein is boiled with alcohol, then treated with ether, and then heated with concentrated hydrochloric acid, a blue solution is produced. This is, according to Cole, due to glyoxylic acid, contained as an impurity in the ether. If this is the case, the Liebermann reaction is identical with that of Hopkins and Cole.

(e) According to Cole, proteins on treatment with furfurol and hydrochloric acid yield a purple-red colour, which is also due to tryptophane. Some proteins containing a carbohydrate group will yield the reaction directly ( $c f$. Molisch-Udransky reaction below).

This series of reactions is only given by those proteins which yield tryptophane on hydrolysis. Gelatin, for example, does not give these reactions.

V. Diazobenzene sulphonic acid in the presence of potassium hydroxide yields an orange to brownish red colour, which on treatment with zinc dust changes, owing to reduction, to a fuchsin colour. The same reaction is given with tyrosine and histidine.

VI. Reactions due to the Presence of a Carbohydrate Group.Certain proteins, which contain a carbohydrate grouping (glycoproteins, and possibly certain albumins, such as egg-albumin and serum-albumin ${ }^{1}$ ), yield reactions indicating the presence of sugars. The chief of these are (a) the Molisch-Udransky reaction, and $(b)$ the orcin reaction.

1 In these cases it is not definitely proved whether the carbohydrate group is actually contained in the protein molecule, or whether the protein is contaminated with a sugar or glyco-protein. 
(a) The Molisch-Udransky Reaction.-Concentrated sulphuric acid is added to a solution of protein containing a few drops of an alcoholic solution of $a$-naphthol. A violet colour is produced which turns yellow on addition of alcohol, ether or sodium hydroxide. If thymol be employed instead of $a$-naphthol a carmine-red colour is produced.

(b) Bial's Modification of the Orcin Reaction.-A small quantity of dried protein is added to 5 c.c. of fuming hydrochloric acid, and the mixture is then warmed. When the protein is nearly all dissolved a little solid orcin is added, and then a drop of ferric chloride solution. After warming for some time a green coloration is produced, which is soluble in amyl alcohol.

VII. Sulphur Reaction.-On warming a protein solution with: sodium hydroxide in the presence of a lead salt (lead acetate) a black coloration is produced owing to the presence of sulphur in the protein molecule.

As already mentioned, the above tests are not common to all the proteins, and they serve, therefore, for qualitatively distinguishing between them in certain cases. Thus, for example, hydroferrocyanic acid gives only a faint precipitate with gelatin; with the proteoses it gives a precipitate which disappears on boiling but reappears on cooling the solution; with peptones it gives no precipitate.

Nitric acid also gives a precipitate with the proteoses, which dissolves on boiling and reappears on cooling; the peptones are not precipitated.

The alkaloidal reagents precipitate the majority of the proteins in acid solution only; the strongly basic protamines, however, can be precipitated in alkaline solution. The peptones are not precipitated by picric or trichloracetic acids, or by potassio-mercuric iodide; they are precipitated, however, by tannic, phosphomolybdic and phosphotungstic acids. The colour reactions, as already mentioned, are due to certain specific groups, which are not common to all proteins. All give the biuret reaction, the peptones giving a characteristic pink coloration.

The Millon reaction, which is due to the presence of tyrosine, is given only very faintly by gelatin; the reaction in this case may be due to an impurity, but according to Mörner the reaction occurs normally if too much reagent be not present. The reaction is not given by reticulin, nor by the protamines, with the exception of cyclopterine.

The Adamkiewicz (Hopkins-Cole) reaction varies also in intensity with the different proteins. It is not given at all by gelatin, which does not yield tryptophane as a product of hydrolysis.

An interesting example of the application of the colour reactions is afforded by Pick, who found considerable differences in the colour reactions of the various fractions of Witte's peptone, obtained by the method which has been already discussed (p. I4).

\section{Section XIII.-The Chemical Composition of Proteins.}

\section{The Nitrogen Content and Distribution.}

Proteins sometimes occur in nature combined with other organic complexes, which have been designated by Hoppe-Seyler as "prosthetic" groups, from which, by gentle chemical treatment (e.g., by 
weak acids at the ordinary temperature), they can be readily freed. These conjugated proteins give the same general chemical reactions as the simple proteins. The chief groups are: (I) the nucleo-proteins, or proteins in combination with a nucleic acid complex; (2) the glycoproteins, or proteins in combination with a complex which can exert a reducing action on alkaline copper solutions [it has not been definitely proved that the prosthetic group in this class is always a carbohydrate]; (3) the chromo-proteins, or proteins containing a chromatogenic group.

It is not proposed to consider under this section the chemical composition of the conjugated proteins; only that of the simple proteins, either those existing as such in nature, or those obtained by the decomposition of conjugated proteins, will be discussed.

The essential constituents of a protein molecule are carbon, hydrogen, nitrogen, oxygen and, in nearly all cases, sulphur. Some proteins contain in addition phosphorus, and the halogens are also found in a limited number of substances of this class.

It is extremely difficult to prepare the majority of proteins free from ash; in some cases the inorganic constituents may be in combination with the organic body (the question of salt formation will be discussed later) and in others simply adsorbed.

The carbon, hydrogen and nitrogen content of a protein varies in substances of very different origin and character within comparatively very narrow limits; the numbers obtained by an ordinary elementary analysis of carbon, hydrogen and nitrogen cannot be regarded as very characteristic. The following analyses will serve as an example:-

\begin{tabular}{|c|c|c|c|c|c|}
\hline Substance. & Origin. & Per $\stackrel{\text { Cent. }}{\text { C }}$ & Per $\stackrel{H}{\mathrm{C}}$ ent. & Per $\stackrel{N}{\text { Cent. }}$ & Observer. \\
\hline Serum-albumin & Horse & $52 \cdot 93$ & $7 \cdot 05$ & 15.89 & Abderhalden. \\
\hline Albumin & Egg & $52 \cdot 75$ & $7 \cdot x 2$ & 5.43 & Hopkins. \\
\hline Edestin & Hemp-seed & $5 \mathrm{I} \cdot 27$ & 6.85 & $x 8 \cdot 76$ & Osborne. \\
\hline Gliadi & Rye & $5 \mathrm{I}^{\circ} \mathrm{O}$ & $6 \cdot 74$ & $18 \cdot 19$ & 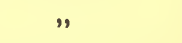 \\
\hline Caseinogen & Cows' milk & $\begin{array}{l}52 \cdot 75 \\
5^{2} \cdot 96\end{array}$ & $\begin{array}{l}0.84 \\
7.05\end{array}$ & $\begin{array}{l}17.72 \\
15.65\end{array}$ & Hammarsten. \\
\hline
\end{tabular}

Although these bodies yield very different amounts of the typical hydrolysis products, and are undoubtedly differently constituted chemically, their contents of carbon and hydrogen vary within comparatively narrow limits. The nitrogen shows larger variations, the plant globulins containing generally between 2 and 3 per cent. more than the typical animal proteins. In certain other cases also the nitrogen content is high, viz., in the proteins of more basic character like the histones and protamines, substances which on hydrolysis yield relatively large quantities of diamino-acids. The thymus histone contains, for example, I8.35 per cent. nitrogen, whilst the protamine salmine, from salmons' testicles, contains no less than $3 \mathrm{I}^{\circ} 69$ per cent. Taken as a whole, the nitrogen does not show, however, very large variations; in fact, the nitrogen content of a mixture is often taken as the index of the amount of protein present.

\section{The Nitrogen Distribution in Proteins.}

It has been already stated that the proteins are essentially polypeptides formed by the condensation of varying numbers of groups of diamino- and monoamino-acids, which are obtained from the proteins by hydrolysis. In addition to these acids, another hydrolysis 
product is in almost all instances obtainable, viz., ammonia. The relative amount of these bodies forms a factor which is characteristic of each individual protein. As to the origin of the ammonia but little is known. It is possibly derivable from asparagine or some allied amide which pre-exists in a conjugated form in the protein molecule. The nitrogen obtainable in the form of ammonia by the hydrolysis of proteins is consequently designated "amide-nitrogen". The nitrogen of the monoamino-acids is known as "monoaminonitrogen," that from the diamino acids, which can be distinguished from the monoamino-acids by the fact that the former only are precipitable by phosphotungstic acid, as "diamino or basic nitrogen". In addition to the nitrogen in the above forms a small quantity of pigmented bodies are formed during hydrolysis; the nitrogen contained in these bodies is generally designated as "humin" nitrogen.

Systematic experiments on the determination of the distribution of nitrogen amongst the various forms of hydrolysis products were carried out by Hausmann in Hof meister's laboratory, and the percentages in the various forms of amide, monoamino, diamino and humin nitrogen are often referred to as the "Hausmann numbers".

In the method originally devised by Hausmann the following operations were carried out: (i) the hydrolysis of the proteins with hydrochloric acid; (ii) the determination of the amide-nitrogen by distillation of the diluted hydrolysis products with magnesium oxide, by means of which the ammonium salts are decomposed, and the estimation of the ammonia evolved by collecting it in a known amount of standard acid; (iii) the precipitation, after distilling off the ammonia, of the residual liquid with phosphotungstic acid, whereby the diamino-acids are precipitated, and the determination of the nitrogen in this precipitate; (iv) the estimation of the nitrogen in the filtrate from the phosphotungstic acid precipitate. This gives the nitrogen of the monoamino-acids (also estimated by the subtraction of the other numbers from the total).

Several objections were raised to the method of Hausmann shortly after it was published, notably by Henderson, Kutscher, and by Schulze and Winterstein. It was urged against it by Henderson that the amounts of "amide-nitrogen" varied when different strengths of acid and varying times of hydrolysis were employed. Kutscher objected to the method on the ground that the diamino-acids were not entirely insoluble in water and excess of phosphotungstic acid. Schulze and Winterstein, furthermore, claimed that certain monoaminoacids such as phenylalanine were precipitable by phosphotungstic acid. Another objection raised was that by treatment with magnesia ammonia was evolved from substances other than ammonium salts.

These objections have been subjected to a critical examination by T. B. Osborne and Harris, and by Gümbel. The former investigators have shown that identical numbers can be obtained where the conditions of experiment vary even within fairly wide limits, although they admit with Henderson that different "amide-nitrogen" numbers, for example, can be obtained by acids of different concentrations and by varying periods of hydrolysis. They show, however, that variations in conditions necessary to produce different results must be large, and that, provided that certain readily specified conditions be adhered to, valuable comparative results can be ob- 
tained, and it is now generally admitted that, when the conditions for determination suggested by Osborne and Harris and by Gümbel are adhered to the "Hausmann numbers" form most valuable factors for the characterisation of the individual proteins.

In the following table are given some of the chief results obtained by Osborne and some results by Kossel and Kutscher, rearranged and recalculated by J. H. Millar, together with some more recent determinations by Gümbel. The numbers for the proteoses and peptones are obtained from the reports of the Guinness Laboratory, vol. i., pt. ii. (1906), pp. 230, 235.

\begin{tabular}{|c|c|c|c|c|c|c|c|}
\hline Group. & Protein. & Source. & z苛 & 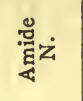 & 量z & 总 & 怠 \\
\hline Protamine & $\begin{array}{l}\text { Salmine } \\
\text { Clupeine } \\
\text { Sturine } \\
\text { Cyclopterine }\end{array}$ & $\begin{array}{l}\text { Salmon-roe } \\
\text { Herring-roe } \\
\text { Sturgeon-roe } \\
\text { Sea-owl }\end{array}$ & $\begin{array}{l}- \\
-\end{array}$ & $\begin{array}{l}0 \\
0 \\
0 \\
0\end{array}$ & 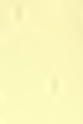 & $\begin{array}{l}87 \cdot 8 \\
83 \cdot 5 \\
83 \cdot 7 \\
67 \cdot 7\end{array}$ & \\
\hline Histones & $\begin{array}{c}\text { Histone } \\
,,\end{array}$ & $\begin{array}{l}\text { Thymus } \\
\text { Cod-fish roe }\end{array}$ & - & $\begin{array}{l}3 \cdot 3 \\
7 \cdot 46\end{array}$ & & $\begin{array}{l}3^{8} \cdot 7 \\
35^{\circ} \mathrm{O}\end{array}$ & \\
\hline $\begin{array}{l}\text { Albumins and } \\
\text { phosphopro- } \\
\text { teins }\end{array}$ & $\begin{array}{l}\text { Leucosine } \\
\text { Conalbumin } \\
\text { Vitellin } \\
\text { Ovalbumin } \\
\text { Caseinogen }\end{array}$ & $\begin{array}{l}\text { Wheat } \\
\text { Egg-white } \\
\text { Egg-yolk } \\
\text { Egg-white } \\
\text { Milk }\end{array}$ & $\begin{array}{l}16 \cdot 93 \\
16 \cdot 11 \\
16 \cdot 28 \\
15 \cdot 51 \\
15 \cdot 62\end{array}$ & $\begin{array}{r}6 \cdot 85 \\
7 \cdot 51 \\
7 \cdot 67 \\
8 \cdot 64 \\
10 \cdot 36\end{array}$ & $\begin{array}{l}69 \cdot 87 \\
65 \cdot 11 \\
62 \cdot 41 \\
68 \cdot 13 \\
66 \cdot 00\end{array}$ & $\begin{array}{l}20 \cdot 67 \\
25 \cdot 82 \\
28 \cdot 56 \\
21 \cdot 27 \\
22 \cdot 34\end{array}$ & $\begin{array}{l}2 \cdot 54 \\
r \cdot 69 \\
r \cdot 35 \\
r \cdot 87 \\
r \cdot 34\end{array}$ \\
\hline Globulins & $\begin{array}{l}\text { Legumelin } \\
\text { Globulin } \\
\text { Legumin } \\
\text { Edestin } \\
\text { Conglutin } \\
\text { Amandin } \\
\text { Glutenin }\end{array}$ & $\begin{array}{l}\text { Pea, etc. } \\
\text { Wheat } \\
\text { Pea, etc. } \\
\text { Hemp-seed } \\
\text { Lupine } \\
\text { Almond } \\
\text { Wheat }\end{array}$ & $\begin{array}{l}\text { r6.09 } \\
18 \cdot 39 \\
17 \cdot 97 \\
18 \cdot 64 \\
18 \cdot 05 \\
19.00 \\
17.49\end{array}$ & $\begin{array}{r}6 \cdot 46 \\
7 \cdot 72 \\
9 \cdot 40 \\
10 \cdot 08 \\
13 \cdot 18 \\
16 \cdot 05 \\
18 \cdot 86\end{array}$ & $\begin{array}{l}68 \cdot 11 \\
53 \cdot 40 \\
60 \cdot 76 \\
57 \cdot 83 \\
57 \cdot 28 \\
60 \cdot 79 \\
68 \cdot 32\end{array}$ & $\begin{array}{l}23 \cdot 05 \\
37 \cdot 10 \\
28 \cdot 82 \\
31 \cdot 70 \\
28 \cdot 58 \\
21 \cdot 84 \\
11 \cdot 72\end{array}$ & $\begin{array}{l}2 \cdot 36 \\
r \cdot 52 \\
0 \cdot 94 \\
0 \cdot 64 \\
0 \cdot 88 \\
0 \cdot 89 \\
r \cdot 08\end{array}$ \\
\hline $\begin{array}{c}\text { Alcohol-soluble } \\
\text { proteins }\end{array}$ & $\begin{array}{l}\text { Zein } \\
\text { Alc. sol. protein } \\
\text { Hordein } \\
\text { Bynin } \\
\text { Gliadin }\end{array}$ & $\begin{array}{l}\text { Maize } \\
\text { Oat } \\
\text { Barley } \\
\text { Malt } \\
\text { Wheat and rye }\end{array}$ & $\begin{array}{l}16 \cdot 13 \\
15 \cdot 67 \\
17 \cdot 21 \\
16 \cdot 26 \\
17 \cdot 66\end{array}$ & $\begin{array}{l}18 \cdot 40 \\
22 \cdot 46 \\
23 \cdot 30 \\
23 \cdot 49 \\
23 \cdot 78\end{array}$ & $\begin{array}{l}77 \cdot 56 \\
68 \cdot 09 \\
69 \cdot 96 \\
68 \cdot 69 \\
70 \cdot 27\end{array}$ & $\begin{array}{l}3 \cdot 03 \\
7 \cdot 84 \\
4 \cdot 47 \\
4 \cdot 61 \\
5 \cdot 54\end{array}$ & $\begin{array}{l}0 \cdot 99 \\
\mathbf{r} \cdot 50 \\
\mathbf{r} \cdot 33 \\
3 \cdot 13 \\
0.79\end{array}$ \\
\hline & Cartilage & $\begin{array}{l}\text { Nasal septum } \\
\text { of pig }\end{array}$ & - & & $72 \cdot 27$ & $12 \cdot 27$ & $3 \cdot 27$ \\
\hline $\begin{array}{l}\text { Sclero-protein } \\
\text { Gluco-proteid }\end{array}$ & $\begin{array}{l}\text { Gelatin } \\
\text { Chondroitin = } \\
\text { sulphuric acid }\end{array}$ & $\begin{array}{l}\text { Commercial } \\
\text { Nasal septum } \\
\text { of pig }\end{array}$ & - & $\begin{array}{r}r \cdot 6 r \\
35^{\cdot} \cdot 27\end{array}$ & $\begin{array}{l}62 \cdot 56 \\
21 \cdot 57\end{array}$ & $\begin{array}{r}35^{\circ} \\
32 \cdot 78\end{array}$ & 93 \\
\hline $\begin{array}{l}\text { Albumose } \\
\text { Albumose } \\
\text { Polypeptide } \\
\text { Polypeptide }\end{array}$ & $\begin{array}{l}\text { Prot-albumose } \\
\text { Hetero-albumose } \\
\text { Glutokyrin } \\
\text { Caseokyrin }\end{array}$ & $\begin{array}{l}\text { Witte's peptone } \\
\text { Witte's peptone } \\
\text { Gelatin } \\
\text { Milk }\end{array}$ & - & $\begin{array}{l}7 \cdot 14 \\
6 \cdot 45 \\
0 \cdot 0 \\
0 \cdot 0\end{array}$ & $\begin{array}{r}68 \cdot 17 \\
57^{\circ} 4 \\
33^{\circ} 0 \\
12 \cdot 0\end{array}$ & $\begin{array}{l}25^{\circ} \cdot 42 \\
38 \cdot 93 \\
66 \cdot 0 \\
88 \cdot 0\end{array}$ & $\begin{array}{c}- \\
- \\
-\end{array}$ \\
\hline $\begin{array}{l}\text { Plant-albumose } \\
\text { Plant-albumose } \\
\text { Plant-albumose } \\
\text { Plant peptose }\end{array}$ & $\begin{array}{l}\text { Malt-albumose I. } \\
\text { Malt-albumose II. } \\
\text { Malt-albumose III. } \\
\text { Malt-peptone I. } \\
\text { Malt-peptone II. }\end{array}$ & Malt & $\begin{array}{c}- \\
- \\
-\end{array}$ & $\begin{array}{r}2 I \cdot 3 \\
12 \cdot 4 \\
8 \cdot 0 \\
3 \cdot 5 \\
6 \cdot 5\end{array}$ & $\begin{array}{l}62 \cdot 0 \\
70 \cdot 8 \\
62 \cdot 0 \\
64 \cdot 3 \\
48 \cdot 8\end{array}$ & $\begin{array}{r}7 \cdot 5 \\
11 \cdot 0 \\
24 \cdot 0 \\
30^{\circ} 5 \\
4 I^{\circ} 0\end{array}$ & $\begin{array}{l}9 \cdot 2 \\
5 \cdot 8 \\
6 \cdot 0 \\
1 \cdot 64 \\
3 \cdot 65\end{array}$ \\
\hline
\end{tabular}




\section{Method.}

The method adopted is the Osborne-Harris modification of the original Hausmann method, with a further modification suggested by Gümbel, viz., the employment of a vacuum at a temperature of $40^{\circ} \mathrm{C}$., for the distillation of the ammonia after treatment with magnesia.

About I gram of protein is boiled with 20 per cent. hydrochloric acid until the solution no longer gives the biuret reaction, usually from seven to ten hours. It is then evaporated at $40^{\circ}$ under diminished pressure to $2-3$ c.c. and the bulk of the hydrochloric acid is thereby removed. The residual solution is then transferred to a flask with about 350 c.c. of water, and a cream of magnesia, which has been freed from every trace of ammonia by prolonged boiling is then added until in slight, but distinct, excess. After distilling and determining the ammonia by warming to $40^{\circ}$ in vacuo, and passing the distillate into a known quantity of a standard acid solution, the solution in the flask is filtered through a nitrogen-free filter paper, and the residue thus collected washed thoroughly with water and the nitrogen determined in it together with the paper by Kjehldahl's method ("humin" nitrogen). The filtered solution is next concentrated to IOO c.c., cooled to $20^{\circ} \mathrm{C}$., 5 grams of sulphuric acid added, and then 30 c.c. of a solution containing 20 grams of phosphotungstic acid and 5 grams of sulphuric acid per IOO c.c. After twenty-four hours the precipitate is filtered off and washed with a solution containing 2.5 grams of phosphotungstic acid and 5 grams of sulphuric acid per IOO c.c. The washing is effected by rinsing the precipitate from the filter into a beaker and returning to the paper three successive times, each portion of the wash solution being allowed to run out completely before the next is applied. About 200 c.c. of washings are thus obtained. The nitrogen contained in the precipitate ("basic" nitrogen) is then determined by transferring it to a Jena glass flask of about 600 c.c. capacity and digesting with 35 c.c. concentrated sulphuric acid for seven or eight hours. During digestion potassium permanganate crystals are added three or four times. In a few cases, when the phosphotungstic acid precipitate is small, less sulphuric acid is used, enough being taken in each case to prevent too violent bumping. The remaining nitrogen, belonging chiefly to monoamino acids, is found by subtracting the sum of the nitrogen found in the preceding operations from the total nitrogen contained in the protein under examination.

Skraup has recently shown that two-thirds of the amidenitrogen is evolved in a very short time, even with the use of dilute acids for hydrolysis.

\section{Section XIV.-The Sulphur, Phosphorus and Halogen Content OF PROTEINS.}

\section{The Sulphur Content.}

Far more characteristic of the individual protein than the percentage of nitrogen is that of the sulphur. Although the latter element is not contained in large quantity, yet the variations in its amount are considerable, and its percentage may be regarded as one of the 
characteristic constants of a protein; it indicates the quantity of the cystine unit present in the molecule.

In the following table the percentage of sulphur present in some typical proteins is given:-

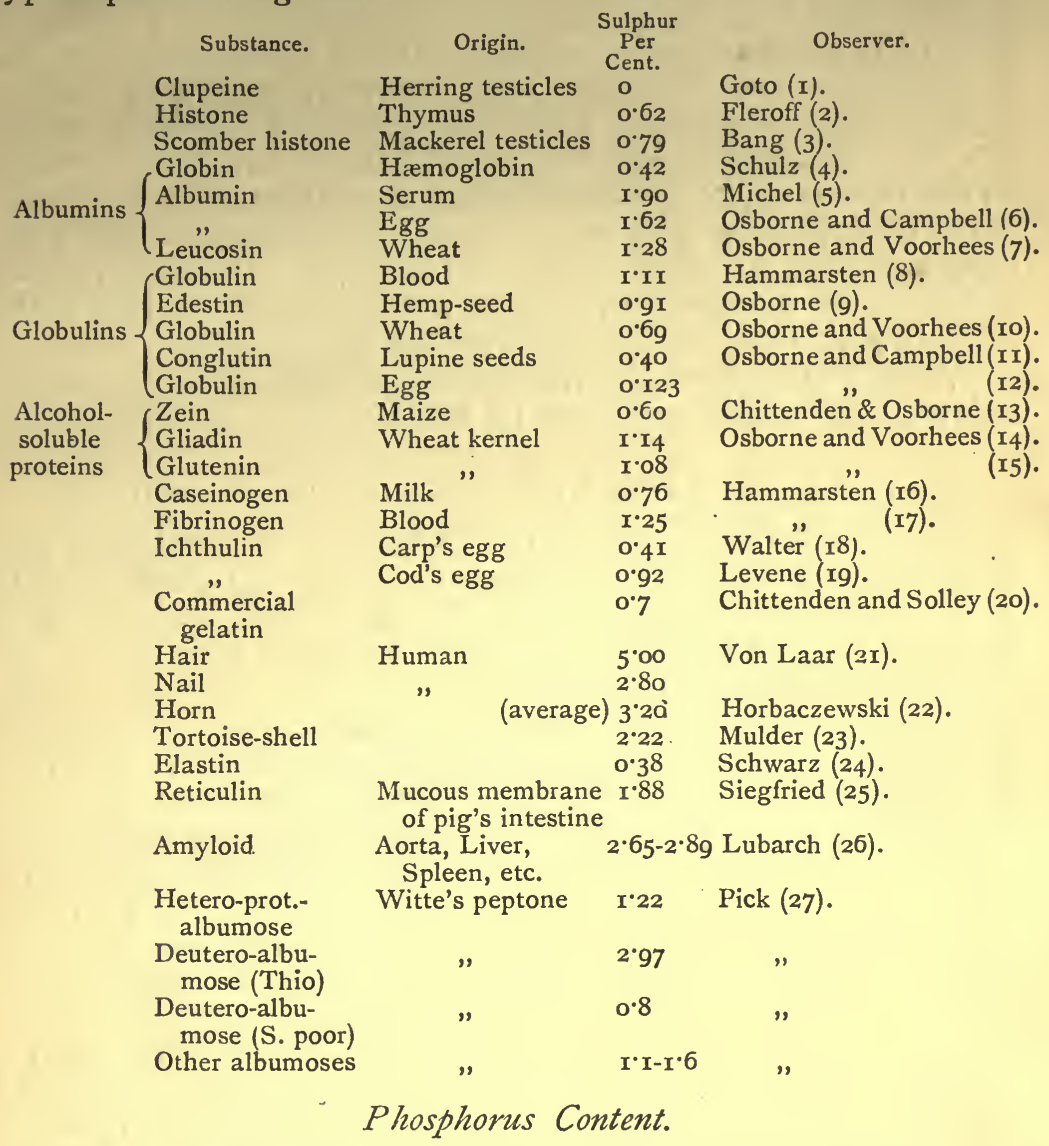

Certain proteins, the phosphoproteins, are characterised by the relatively large amount of phosphorus they contain. They must be distinguished from the nucleo-proteins, in which the phosphorus is contained in the prosthetic group, nucleic acid, and not in the protein part of the molecule. The typical phosphoprotein caseinogen contains, according to Hammarsten, 0.847 per cent. of phosphorus; ovovitellin contains, according to Plimmer, $I^{*} I$ per cent.; ichthulin from carps' eggs contains 0.43 per cent. (Walter, loc. cit., in the table), and the corresponding substance from cods' eggs 0.92 per cent. (Levene). Plimmer and Scott have recently shown that the phosphoproteins are easily decomposed by I per cent. caustic soda, and are thus readily distinguished from the nucleo-proteins. Ordinary proteins contain very small quantities, if indeed, any phosphorus.

\section{Halogen Content.}

Certain proteins contain very appreciable quantities of halogen. The chief of these is the thyro-globulin of the thyroid gland, in which 
iodine was first detected by Baumann in 1895 . The iodine containing protein has been exhaustively studied by Oswald. The amount of iodine varies in different preparations; Oswald found 0.46 per cent. in the thyro-globulin prepared from pigs' thyroids, 0.86 from ox thyroid, and 0.39 from sheep's thyroid ; in human thyroid he found from 0.07 to $0.5 \mathrm{I}$ per cent. (the latter after potassium iodide administration).

Halogens have also been found in certain marine animals, especially in the skeletons. The axial system of Gorgonia cavolini contains, according to Drechsel, about 8 per cent. iodine (calculated on the amount of dry substance), which is combined with the protein substance known as gorgonin. Sponges also contain iodised proteins according to Hundeshagen and Harnack. The latter by the hydrolysis of sponges with mineral acids isolated the protein body iodospongin containing 9 per cent of iodine.

Various other proteins with halogen content have been recently isolated from marine organisms by Mörner.

\section{Section XV.-The Tyrosine Factor of Proteins.}

Each individual protein yields on hydrolysis certain definite quantities of amino acids. The method of determining these quantities with any degree of accuracy is unknown for the majority of the amino acids; even by the esterification method of Emil Fischer only approximate results are obtained.

There are, however, at least one or two hydrolysis products, of which the yield can be readily determined when only small quantities of the protein from which they are derived is available. The quantity of the cystine group can be estimated by a determination of the total sulphur of the molecule ${ }^{1}$ (see p. 30). Another hydrolysis product, the amount of which can be readily determined, is tyrosine; it is probable that the tyrosine factor (i.e., the percentage of tyrosine liberated on hydrolysis) will form a definite characteristic for each protein.

There are several earlier investigations on this subject, which are summarised in a paper by Reach. In the researches described in this and the previous papers the tyrosine was obtained in the form of crystals, which were weighed. A more accurate method is, however, due to J. H. Millar, who has shown that tyrosine can be readily estimated in even complex mixtures by titrating a solution of a protein containing hydrochloric acid and potassium bromide with a standard solution of potassium bromate, until a potassium iodidestarch indicator denotes the presence of free bromine. The reaction which takes place may be represented by the following equations :-

$\mathrm{NaBrO}_{3}+5 \mathrm{KBr}+6 \mathrm{HCl}=\mathrm{NaCl}+{ }_{5} \mathrm{KCl}+3 \mathrm{Br}_{2}+3 \mathrm{H}_{2} \mathrm{O}$.

$\mathrm{C}_{6} \mathrm{H}_{4} \cdot(\mathrm{OH}) \cdot \mathrm{CH}_{2} \cdot \mathrm{CH}\left(\mathrm{NH}_{2}\right) \cdot \mathrm{COOH}+4 \mathrm{Br}_{2} \mathrm{C}_{6} \mathrm{H}_{2} \mathrm{Br}_{2} \cdot(\mathrm{OH}) \cdot \mathrm{CH}_{2} \cdot \mathrm{CH} \cdot\left(\mathrm{NH}_{2}\right) \cdot \mathrm{COOH}$.

According to the theory of these equations $\mathrm{I} \cdot 765$ grams of bromine would be required for each gram of tyrosine, or about 18.8 c.c. $\frac{\mathrm{N}}{5}$ potassium bromate solution. This method has not yet been much applied to the investigations of the hydrolysis products of proteins. Adrian Brown and E. T. Millar have, however, recently shown

${ }^{1}$ On the assumption that cystine is the only sulphur-containing group. 
that in the proteins they investigated (edestin and egg-albumin) scission of tyrosine by tryptic digestion is a very rapid process (whereas there is no scission by peptic digestion); the whole of the tyrosine from edestin and egg-proteins was liberated in from one to three hours. It is conceivable that the determination of tyrosine in a protein by this method, after a short tryptic digestion, may afford another valuable factor for the characterisation of proteins.

\section{Section XVI.-Salt Formation by Proteins. Combina- TION WITH ACIDS AND BASES.}

One class of the proteins, viz., the protamines, react as strong bases, giving alkaline solutions and characteristic salts with acids; others, of which caseinogen may be taken as an example, react as acids, giving salts on treatment with bases. The majority of the proteins, however, possess an amphoteric reaction, acting as bases towards acids and as acids towards bases.

For reasons already mentioned in the introduction, the determination of the acidity or basicity of proteins offers several difficulties. The chief of these is due to their high molecular weight; relatively large amounts of protein will require for neutralisation but small amounts of acids and bases. Furthermore, as the proteins in several instances act only as very weak acids or bases, the salts readily undergo hydrolysis in aqueous solutions; the ordinary methods of titration, with the use of indicators, are not therefore available for determining their combining weights with acids and bases. Consequently it is necessary to employ indirect methods, of which the following are the chief:-

\section{A. Physical Methods.}

I. The measurement of electrolytic conductivity when acids or bases are added to protein solutions.

II. The measurement of the potential of concentration cells, and the changes produced when proteins are added to either electrode.

III. The determination of the influence of the addition of proteins on the depression of the freezing points of solutions of acids and bases.

IV. The determination of the influence of the addition of proteins on the rate of hydrolysis of cane-sugar and esters by acids and bases.

\section{B. Chemical Methods.}

I. Direct titration in presence of indicators.

II. Determination of the solubility in acids and bases of proteins which are insoluble in pure water.

III. Determination of the acidity of the filtrate from protein precipitates produced by neutral salts or alkaloidal reagents in solutions containing an excess of acids.

It is proposed to consider these general methods first, and afterwards to refer to some of the more recent investigations on the salt formation of individual proteins. 


\section{A. Conductivity Method.}

This method was first applied by Sjöqvist.

If a strong base be gradually added to a solution of a strong acid, the volume of the solution being kept constant, and the electrolytic conductivity be determined after each addition, it will be found that it gradually diminishes, until a certain minimum is reached, after which it gradually increases. This minimum represents the point at which the acid is completely neutralised by the base. When potassium hydroxide is added to hydrochloric acid the conductivity curve, where the ordinates represent the molecular conductivity, and the abscissæ the amount of alkali, is represented by a descending and an ascending straight line enclosing a sharp angle. The attainment of the minimum point is due to the fact that both the acid and the base are better conductors than the salt which is formed by their neutralisation of one another. If, instead of a strong base, a weak base like ammonia be employed, which is a bad conductor, the conductivity rises but slightly after the neutralisation point is reached; at this point the curve becomes nearly parallel with the abscissa. A somewhat similar curve is obtained when egg-white is gradually added to a solution of acids, and by a study of such curves Sjöqvist has endeavoured to throw some light on the salt formation of the egg-proteins with acids.

Two additional factors have in this case to be taken into account, viz.: (a) the conductivity due to the protein addition; (b) the decrease of conductivity due to the lessened velocity of the ions owing to the increased internal resistance of the fluid produced by the addition of the proteins.

The conductivity of the protein alone is readily determined. This is probably due entirely to combined or adsorbed salts. Although the protein solutions used in Sjöqvist's experiments were carefully dialysed, they could not be obtained ash free. The ash was found to consist of a mixture of calcium sulphate and phosphate.

The internal friction factor is not so readily determined. The alteration of the conductivity of the acid due to this factor can only be determined indirectly, viz., by determining the decrease of conductivity of a neutral salt solution produced by repeated additions of known quantities of protein, and the ratio of this decrease to the decrease produced in acids by other non-electrolytes which increase internal resistance, and upon which acids do not chemically act. It was found, for example, in the experiments of Sjöqvist, that each gram of protein added to a $0.05 \mathrm{~N}$ sodium chloride solution produced (after allowance for the conductivity of the protein alone) a diminution of I. 52 per cent. of the total molecular conductivity. Now the mean decrease produced by six other non-electrolytes, which increase internal friction, was found by Arrhenius to be as follows: for $\mathrm{NaCl}, 2 \cdot 2 \mathrm{I}$ per cent. ; for $\mathrm{HCl}, \mathrm{I} .84$ per cent. ; for $\mathrm{HNO}_{3}$, I.88 per cent. If, now, the ratio of decrease produced by proteins is the same as for other non-electrolytes, then the diminution of conductivity produced by the addition of each gram of protein to 100 c.c. of a $0.05 \mathrm{~N}$ hydrochloric acid solution is $\mathrm{I} \cdot 52 \times \frac{\mathrm{I} \cdot 84}{2 \cdot 2 \mathrm{I}}=\mathrm{r} \cdot 26$ per cent. The actual diminution produced when egg-white solution is added to $0.05 \mathrm{~N}$ 
hydrochloric acid was much greater than this: the diminution was due to actual neutralisation, and not to mere increase in internal friction.

Sjöqvist determined the conductivity of the $0.05 \mathrm{~N}$ hydrochloric acid solution after the addition of varying amounts of egg-proteins, with the following results:-

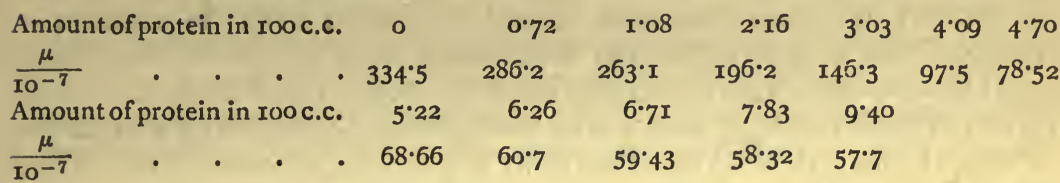

It is evident from the above numbers that in the last determinations far more protein was added than was necessary to neutralise the hydrochloric acid. After making corrections for the increased conductivity, due to the protein added, and the diminished conductivity due to friction, Sjöqvist calculated that the molecular conductivity of the hydrochloride of the egg-proteins in $0^{\circ} 05 \mathrm{~N}$ solution was $53 \times 10^{-7}$, and, by interpolation in the curve, that neutralisation of $0.05 \mathrm{~N}$ hydrochloric acid solution was attained when $4^{\circ} \mathrm{I}$ grams of protein had been added to 100 c.c. From this the equivalent of egg-protein was calculated to be 820 . This number obtained with sulphuric acid was found to be 840 , and with nitric acid 720 . The average is not far removed from 800 .

There is one other factor in these experiments which deserves mention. It was noticed that in the case of the neutralisation of hydrochloric acid by ammonia the curve first descends, and then suddenly becomes almost parallel with the abscissa, forming thus two straight lines enclosing a sharp angle. In the case of the protein hydrochloric acid neutralisation curve there is no sharp break, but the curve is rounded off. This is due to the fact that hydrolysis of the protein hydrochloride can take place according to the equation

$$
\text { Alb. } \mathrm{HCl}+\mathrm{H}_{2} \mathrm{O}=\mathrm{Alb} . \mathrm{OH}+\mathrm{HCl} \text {. }
$$

This hydrolysis is suppressed in the presence of a large excess of protein (i.e., in the calculations of conductivity given above).

The amount of hydrolysis has been determined by Sjöqvist in the following way. He calculated the molecular conductivity of a solution produced by adding the inorganic constituents of 4 grams of protein to 100 c.c. of $0.05 \mathrm{~N}$ hydrochloric acid (the quantity necessary for " neutralisation," vide supra). Such a solution would contain known quantities (which were determined by analysis) of free $\mathrm{HCl}, \mathrm{CaCl}{ }_{2}, \mathrm{H}_{3} \mathrm{PO}_{4}$ and $\mathrm{H}_{2} \mathrm{SO}_{4}$ (produced by the action of a large excess of $\mathrm{HCl}$ on the original salts $\mathrm{CaSO}_{4}$ and $\left.\mathrm{Ca}_{3}\left(\mathrm{PO}_{4}\right)_{2}\right)$. For such a solution $\mu$ was found to be $314 \times 10^{-7}$. The conductivity was next calculated for this solution when the free acids were neutralised by egg-proteins without hydrolysis, and after making correction for decreased conductivity due to viscosity. (The molecular conductivity of egg-protein hydrochloride was found as shown above to be $53 \times 10^{-7}$, and that of the sulphate and phosphate were determined in a similar way in other experiments.) $\mu$ for this neutralised solution was calculated to be $55^{\circ} 66 \times 10^{-7}$. The actual observed value was $100^{\circ} 5$. Now as $314 \times 10^{-7}$ represents the value for total 
hydrolysis of the hydrochloride (the protein having no conductivity), and $55^{\circ} 66 \times \mathrm{ro}^{-7}$ represents the value when no dissociation takes place, then using the ordinary formula when $x$ represents the proportion hydrolysed-

$$
3^{1} 4 x+(\mathrm{x}-x) 55^{\circ} 66=\mathrm{I00}^{\circ} 5
$$

whence $x=0.174$, from which it was calculated that 17.4 per cent. of protein hydrochloride was hydrolysed when a $0.05 \mathrm{~N}$ solution of hydrochloric acid solution was neutralised with egg-proteins.

These experiments of Sjöqvist were carried out with the whole of the proteins of egg-white, and therefore probably with a mixture. Some of the calculations, furthermore, are approximations. They have, however, been described in some detail, as they demonstrate in a clear manner the salt formation when proteins are treated with acids; they also indicate the methods for determination of the hydrolysis of such salts.

A similar set of conductivity determinations with the proteins of horse serum is due to Mellanby.

\section{A. II. Electric Potential Method.}

This method has been employed by Bugarsky and Liebermann.

According to the theory of Nernst, the electro-motive force of a galvanic element constituted according to the following scheme-

Platinum laden with $\mathrm{H}_{2}$ | Acid | Base | Platinum laden with $\mathrm{H}_{2}$

depends on the concentration of the hydrogen ions in the acid and base solutions.

The addition of a protein to either the acid or base would in the event of combination and salt formation alter the concentration of the various ions in solution.

The electro-motive force of such an element as the above can, according to the Nernst theory of electrolytic solution pressure, be expressed by the following equation:-

$$
\pi=\frac{\mathrm{RT}}{\mathrm{E}_{\mathrm{O}}} \text { nat } \log \frac{\mathrm{C}_{\mathrm{H}}}{x_{\mathrm{H}}} \quad \cdot \quad \cdot \quad \cdot
$$

where $\mathrm{R}$ is the ordinary gas constant, $\mathrm{T}$ the absolute temperature, $\mathrm{E}$ the quantity of electricity transported by I gram equivalent of an electrolyte, $\mathrm{C}_{\mathrm{H}}$ the concentration of the hydrogen ions in the acid, and $x_{\mathrm{H}}$ the concentration of hydrogen ions in the base. If the electromotive power be expressed in volts, the quantity of electricity in coulombs, and the electrical energy I volt-coulomb $=10,000,000$ ergs, and the experiments be all carried out at a constant temperature $\left(25^{\circ} \mathrm{C}\right.$. $)$, then $\frac{\mathrm{RT}}{\mathrm{E}_{\mathrm{O}}}$ is a constant $=0.0256$. rithms,

If now the Brigg logarithms be substituted for the natural loga-

$$
\pi=0.0590 \log _{10} \frac{\mathrm{C}_{\mathrm{H}}}{x_{\mathrm{H}}} .
$$

The hydrogen ions in the acid depend on the dissociation of the acid in the concentration employed in the experiments.

In the base solution (sodium hydroxide was used in the experi- 
ments), if $\mathrm{C}_{\mathrm{H}}$ represent the concentration of the hydrogen ions, and $\mathrm{C}_{\mathrm{OH}}$ that of the hydroxyl ions, then according to the law of mass action,

$$
\mathrm{C}_{\mathrm{H}} \cdot \mathrm{C}_{\mathrm{OH}}=\text { constant }=\mathrm{K} \text {. }
$$

In the presence of sodium hydroxide the concentration in the hydroxyl ions is decreased (owing to dissociation into $\stackrel{+}{\mathrm{Na}}$ and $\overrightarrow{\mathrm{O}} \overline{\mathrm{H}}$ ). If now $x_{\mathrm{H}}$ represent (as above) the concentration of the hydrogen ions, and $\mathrm{C}_{\mathrm{OH}}$ the concentration of the hydroxyl ions due to the presence of the alkali, then (dissociation of water being negligible)

$$
x_{\mathrm{H}} \cdot \mathrm{C}_{\mathrm{OH}}=\mathrm{K} \text { and } x_{\mathrm{H}}=\frac{\mathrm{K}}{\mathrm{C}_{\mathrm{OH}}} .
$$

Substituting this value in equation (I), it is found that

$$
\pi=0.059 \log _{10} \frac{\mathrm{C}_{\mathrm{H}} \cdot \mathrm{C}_{\mathrm{OH}}}{\mathrm{K}} .
$$

Suppose now that the ionic concentration of the acid be altered by the addition of protein which forms a salt with the acid, a change in the electro-motive force will follow. The concentration of the hydrogen ions in the sodium hydroxide $\left(\mathrm{C}_{\mathrm{NaOH}}\right)$ will remain unchanged. If $\mathrm{C}_{\mathrm{HCl}}$ represent the ionic concentration of the original acid solution and $\mathrm{C}_{\mathrm{H}}$ that after addition of protein, and $\mathrm{E}_{\mathrm{O}}$ the original electromotive force and $\mathrm{E}$ the changed force, then

Whence,

$$
\begin{aligned}
\mathrm{E}_{\mathrm{O}} & =0.059 \log _{10} \frac{\mathrm{C}_{\mathrm{HCl}} \cdot \mathrm{C}_{\mathrm{NaOH}}}{\mathrm{K}}, \\
\text { and } \mathrm{E} & =0.059 \log _{10} \frac{\mathrm{C}_{\mathrm{H}} \cdot \mathrm{C}_{\mathrm{NaOH}}}{\mathrm{K}} \text {. }
\end{aligned}
$$

$$
\mathrm{E}-\mathrm{E}_{\mathrm{O}}=0 \cdot 059 \log _{10} \frac{\mathrm{C}_{\mathrm{HCl}}}{\mathrm{C}_{\mathrm{H}}}, 1
$$

and similarly for alkalis, $\mathrm{E}-\mathrm{E}_{\mathrm{O}}=0.059 \log \frac{\mathrm{C}_{\mathrm{NaOH}}}{\mathrm{C}_{\mathrm{OH}}}$.

The experiments were carried out with $0.05 \mathrm{~N}$ acid and alkali solutions with a $0.05 \mathrm{~N}$ sodium chloride solution interposed. The electro-motive force was determined by a compensation method, a Clark cell being used as standard. Values for $\mathrm{E}-\mathrm{E}_{\mathrm{O}}$ and

1 This equation is not strictly correct, for between the sodium hydroxide and acid solutions there is a layer of sodium chloride, and there are consequently potential differences between the acid | salt and alkali | salt solutions. If $\phi$ represent the former of these differences, and $\psi$ the latter, then the equations become

$$
\begin{aligned}
\mathrm{E}_{\mathrm{O}} & =0.059 \log _{10} \frac{\mathrm{C}_{\mathrm{HCl}} \cdot \mathrm{C}_{\mathrm{NaOH}}}{\mathrm{K}}-\phi-\psi, \\
\text { and } \mathrm{E} & =0.059 \log _{10} \frac{\mathrm{C}_{\mathrm{H}} \cdot \mathrm{C}_{\mathrm{NaOH}}}{\mathrm{K}}-\phi_{\mathrm{O}}-\psi .
\end{aligned}
$$

$\psi$ remaining the same in both equations and the ionic concentration in the alkali not altering. Then

$$
\mathrm{E}-\mathrm{E}_{\mathrm{O}}=0.059 \log _{10} \frac{\mathrm{C}_{\mathrm{HC} 1}}{\mathrm{C}_{\mathrm{H}}}-\phi-\phi_{\mathrm{O}}
$$

$\phi-\phi_{\mathrm{O}}$ is small compared with the other number and was neglected in calculating the value $\frac{\mathrm{C}_{\mathrm{HCl}}}{\mathrm{C}_{\mathrm{H}}}$. 
$\log _{10} \frac{C_{H C 1}}{C_{H}}$ were plotted as ordinates and abscissæ, and a curve drawn. $\mathrm{By}$ means of this curve the value $\frac{\mathrm{C}_{\mathrm{HCl}}}{\mathrm{C}^{\mathrm{H}}}$ could be ascertained by each experimentally determined value $\mathrm{E}-\mathrm{E}_{\mathrm{O}}$.

The following were some of the results obtained :-

\begin{tabular}{|c|c|c|c|}
\hline \multicolumn{2}{|c|}{ Egg Protein +0.05 $\mathrm{HCl}$. } & \multicolumn{2}{|c|}{ Egg-Protein + $0.05 \mathrm{NaOH}$} \\
\hline $\begin{array}{l}\text { Protein, Grams per } \\
\text { Ioo c.c. Solution. }\end{array}$ & $\begin{array}{l}\text { I'er Cent. HCl } \\
\text { Combined. }\end{array}$ & $\begin{array}{l}\text { Protein, Grams per } \\
\text { I00 c.c. Solution. }\end{array}$ & $\begin{array}{l}\text { Per Cent. } \mathrm{NaOH} \\
\text { Combined. }\end{array}$ \\
\hline $\begin{array}{l}0 \\
0.4 \\
0.8 \\
I \cdot 6 \\
3 \cdot 2 \\
6 \cdot 4 \\
12 \cdot 8\end{array}$ & $\begin{array}{l}\text { o } \\
9.0 \\
18.9 \\
33 \cdot 3 \\
60 \cdot 2 \\
99 \cdot 56 \\
99.67\end{array}$ & $\begin{array}{r}\text { o } \\
0.8 \\
\mathbf{1} \cdot 6 \\
3 \cdot 2 \\
6.4 \\
\mathbf{2} \cdot 8\end{array}$ & $\begin{array}{l}0 \\
14 \cdot 4 \\
27 \cdot 4 \\
60 \cdot 2 \\
97^{\circ} 0 \\
99^{\circ} 88\end{array}$ \\
\hline
\end{tabular}

From the above table it is clear that the egg-protein combines both with acid and alkali, and it must be conceded that Bugarsky and Liebermann have by this method clearly demonstrated the amphoteric character. The addition of protein to sodium chloride in another form of galvanic cell produced no change in electro-motive force; the combination took place only with bases and acids.

\section{A. III. Depression of Freezing-Point Methods.}

Bugarsky and Liebermann also employed this method. They determined the depression of the freezing point caused by the addition of definite quantities of protein to pure water $(\delta)$. They then added the same quantities to $0.05 \mathrm{~N}$ hydrochloric acid, sodium hydroxide and sodium chloride solutions, and determined the depression in the freezing points of these solutions. If $\mathrm{D}$ be the depression of the freezing point of these solutions before the addition of protein, and $\Delta$ the observed depression after addition of the protein, it was found in the case of the acid and the base that $\Delta$ was less than $D+\delta$. In the case of the salt $\Delta=$ approx. $\mathrm{D}+\delta$. This indicated the diminution of the number of molecules in solution, due to the combination of the protein with acids or bases. No combination took place with the salt. These experiments confirm the results obtained by the electric potential method.

\section{A. IV. Hydrolysis of Cane-Sugar and Esters by Acids and Bases in Presence of Proteins.}

This method was originally employed by Hoffmann for determining the free hydrochloric acid in gastric contents. It has also been employed by $\mathrm{O}$. Cohnheim for estimating the combining powers of various products of protein digestion with hydrochloric acid, and by Hardy for determining the amount of hydrolysis in the hydrochloric acid compounds of serum-globulin. More recently still it has been applied by B. Moore for investigation of gastric contents 
in pathological cases. Cane-sugar on hydrolysis is converted into a mixture of glucose and fructose according to the equation

$$
\mathrm{C}_{12} \mathrm{H}_{12} \mathrm{O}_{11}+\mathrm{H}_{2} \mathrm{O}=\mathrm{C}_{6} \mathrm{H}_{12} \mathrm{O}_{6} \text { (glucose) }+\mathrm{C}_{6} \mathrm{H}_{12} \mathrm{O}_{6} \text { (fructose), }
$$

whilst methyl acetate is converted by hydrolysis into a mixture of methyl alcohol and acetic acid:-

$$
\mathrm{CH}_{3} \cdot \mathrm{COOCH}_{3}+\mathrm{H}_{2} \mathrm{O}=\mathrm{CH}_{3} \cdot \mathrm{COOH}+\mathrm{CH}_{3} \cdot \mathrm{OH} \text {. }
$$

The rate at which these reactions take place is proportional to the concentration of the hydrogen ions present (i.e., in sufficient dilution of the acid), when the same amounts of ester or sugar are employed in comparative estimations. If combination between acid and protein take place the addition of the latter will diminish the effective concentration of the former.

If now two parallel experiments be carried out with the same concentrations of sugar or ester, both in the presence of known (but not necessarily the same) concentrations of acids, but one in the presence of known amount of protein and the other without, then according to Wilhelmi's logarithmic law, the amounts of sugar or ester hydrolysed can be represented by the following equations:-

$$
\begin{aligned}
\mathrm{K} & =\frac{\mathrm{I}}{t} \cdot \log \frac{\mathrm{A}}{\mathrm{A}-x}, \\
\mathrm{~K}^{\prime} & =\frac{\mathrm{x}}{t} \cdot \log \frac{\mathrm{A}}{\mathrm{A}-x^{\prime}},
\end{aligned}
$$

where $\mathrm{K}$ is the reaction constant in the experiment when protein is absent, and $\mathrm{K}^{\prime}$ the constant when it is present, $\mathrm{A}$ is the original amount of sugar or ester, and $x$ and $x^{\prime}$ the amounts hydrolysed in the time $t$, in the presence and absence of protein respectively.

Then

$$
\frac{\mathrm{K}}{\mathrm{K}^{\prime}}=\frac{\log \mathrm{A}-\log (\mathrm{A}-x)}{\log \mathrm{A}-\log \left(\mathrm{A}-x^{\prime}\right)^{\prime}}
$$

If now $d$ be the concentration of the acid when no protein is present and $\mathrm{Z}$ be the effective concentration in the parallel experiment with protein, then

$$
Z=\frac{\mathrm{K}^{\prime} \cdot d}{\mathrm{~K}}
$$

By subtracting $Z$, found thus, from the original concentration, the amount of acid that had entered into combination with the known amount of added protein can be readily determined.

Cohnheim determined the combining powers of certain proteoses, prepared by the methods of Kühne and Chittenden, with the following results $\left(\right.$ at $40^{\circ} \mathrm{C}$.): Prot-albumose in a concentration of $2 \frac{1}{2}$ per cent. combines with $4^{*} 3^{2}$ per cent. of its weight of hydrochloric acid and in a concentration of 1.25 per cent. with only 3.5 per cent.; in a concentration of 5 per cent., however, it combines with as much as $4^{\circ} 9$ per cent. of its weight of acid. Deutero-proteose combines with 5.48 per cent., hetero-albumose with $8 \cdot 16$ per cent., and antipeptone with 15.87 per cent. of their weights of hydrochloric acid in $2 \frac{1}{2}$ per cent. solutions at $40^{\circ} \mathrm{C}$.

With the exception of antipeptone, which is a strong base, the proteoses investigated appear to combine with less hydrochloric acid in diminished concentrations. This is due to the fact that in dilute solutions a certain amount of hydrolysis occurs :-

$$
\text { Alb. } \mathrm{Cl}+\mathrm{H}_{2} \mathrm{O}=\mathrm{Alb} . \mathrm{OH}+\mathrm{HCl} \text {. }
$$


The method has been applied by Hardy (see below, p. 53) for investigating the amount of hydrolysis which takes place in dilute solutions after a protein has been neutralised, the neutralisation point having been determined by other methods.

The method is of somewhat limited application, owing to the fact that most proteins are hydrolysed to some extent even by dilute acids.

\section{B. I. Direct Titration in the Presence of Indicators.}

This method is quite effective in the case of strong bases, such as the protamines. It requires to be applied with some care in the majority of cases, owing to a variety of circumstances, such as the hydrolysis of the salts in dilute solutions, and the capacity for the formation of acid and basic salts. Particular stress must also be laid upon the choice of indicators. The method is discussed in some detail below, in considering the researches on certain individual proteins.

\section{B. II. The Determination of the Solubility of Proteins which are Insoluble in Water, in Acids and Bases.}

This method is applicable to a limited number of proteins only, e.g., to the globulins. This is also discussed in greater detail below.

\section{B. III. The Determination of the Acidity of the Filtrates from Protein Precipitates Produced by Neutral Salts or Alkaloidal Reagents.}

This method has been employed by Spiro and Pemsel, Cohnheim and Krieger, and von Rhorer.

Spiro and Pemsel added acids and alkalis in excess to protein solutions. They then precipitated the proteins by ammonium sulphate, and estimated the acid or base remaining in the filtrate. They assumed that the combination of acid or base with protein could be precipitated by salts in the same way as the protein itself, and arrived thus at conclusions as to the amount of acid or base which could enter into combination with proteins. This method has been but little employed, owing to the difficulty of maintaining solutions of ammonium sulphate in a state of complete neutrality.

Cohnheim and Krieger employed a similar method, using, however, alkaloidal reagents, assuming that the acid salt of the protein and the reagent enter into double decomposition, according to such an equation as the following :-

Protein hydrochloride + Calcium phosphotungstate $=$ Protein phosphotungstate $+\mathrm{CaCl}_{2}$.

If to protein containing excess of acid, calcium phosphotungstate be added, the total acidity of the solution, as determined by titration, would be diminished, owing to the combination of acid and protein, and subsequent double decomposition of the salt thus formed with the alkaloidal reagent. Other reagents used were sodium picrate, calcium trichloracetate and potassium mercuric iodide.

The method of Cohnheim and Krieger was subjected to a critical examination by von Rhorer, who has shown that, as originally carried out, it is not free from certain errors.

When, for example, calcium phosphotungstate is used as precipi- 
tant, the filtrate after precipitation of the protein should contain calcium chloride, excess of calcium phosphotungstate and hydrochloric acid. As hydrochloric acid is much stronger than phosphotungstic the calcium salt of the latter is decomposed, and the filtrate contains as a matter of fact chiefly calcium chloride and phosphotungstic acid. The latter acid cannot be accurately titrated with the use of rosolic acid, which was employed by Cohnheim and Krieger as an indicator. Certain of the conclusions drawn by these observers, therefore, as to the dissociation of the hydrochlorides of proteins are erroneous.

Another source of error has also been discovered by von Rhorer, viz., that the bulky precipitates can adsorb certain quantities of acid from solution. If a large excess of acid be present part of this excess will be carried down; it can, however, be recovered by sufficiently washing the precipitate. The statement of Cohnheim and Krieger that the amount of acid entering into combination with the protein depends on the amount originally present in solution is erroneous; the larger the quantity in solution the larger the quantity carried down by the precipitate; by thoroughly washing the latter, and estimating the acid in the washings, the error due to adsorption can be readily eliminated.

Von Rohrer found that the precipitation method yields reliable results if calcium picrate or potassium mercuric iodide be employed as precipitants (provided, of course, that the precipitates be thoroughly washed). By means of the latter reagent, he estimated the equivalent combining weight of crystallised egg-albumin as $98 \mathrm{r}$, whereas Sjöqvist estimated it for dialysed egg-white at 800 (see p. 4I).

Owing to its simplicity, the method seems worthy of further application.

\section{The Salt Formation of Individual Proteins.}

The salt formation of some individual proteins has been investigated in detail. Many of the general principles mentioned above are well illustrated by these investigations. The following will receive some more detailed consideration :-

(a) The salt formation of edestin, according to the investigations of Osborne.

(b) The salt formation of caseinogen, according to the investigations of Lacqueur and Sackur.

(c) The salt formation of serum-globulin, according to the investigations of Hardy.

\section{The Salt Formation of Edestin (Osborne).}

Owing to the ease with which edestin is obtained in quantity, and to the fact that it can be recrystallised and obtained in an apparently homogeneous state, it forms a very suitable substance for investigation.

Osborne noticed that all the crystalline edestin preparations obtained by the deposition of the protein from warm salt solutions are capable of neutralising small quantities of potassium hydroxide solution when phenol phthalein is used as an indicator; some even are slightly acid to litmus. Out of twenty preparations examined, eight required 0.2 to 0.5 c.c. $\frac{\mathrm{N}}{\mathrm{IO}}$ potassium hydroxide to produce a 
neutral reaction to litmus; the preparations required from 0.85 to $\mathrm{I}^{\cdot} 5$ c.c. to produce a neutral reaction to phenol phthalein when I gram of the protein was employed. The causes of this acidity were investigated by treating suspensions of known quantities of edestin with potassium hydroxide $\left(\frac{\mathrm{N}}{\mathrm{IO}}\right)$ solution until neutral with phenol phthalein, filtering off the undissolved protein and certain quantities of protein precipitated by the addition of alkali (as the edestin crystals are partially soluble in water, as will be explained later), and estimating quantitatively the constituents of the filtrate. These consisted of a certain amount of organic matter together with potassium and sodium salts of hydrochloric and sulphuric acids. The following conclusions were drawn by Osborne as to the nature of edestin crystals :-

(I) That edestin is a basic body which forms true salts with acids.

(2) That the preparations, as obtained by crystallisation from salt solutions, react either weakly acid or neutral to litmus and are salts of a basic protein.

(3) That by the addition of caustic alkalis to these preparations until the mixture no longer acts acid towards phenol phthalein, these salts can be decomposed ; by the analysis of the filtrate from the protein after this treatment the nature of the salts can be determined.

(4) The edestin preparations obtained by recrystallisation from sodium chloride consist principally of chlorides (as the filtrate after neutralisation with alkali contains chiefly chlorides); if prepared by crystallisation from ammonium sulphate they consist chiefly of sulphates.

(5) The edestin preparations, as ordinarily prepared by crystallisation from sodium chloride, are appreciably soluble in water. The part which is soluble in water requires twice as much alkali for neutralisation, with phenol phthalein as indicator, as the part which is insoluble.

(6) If the molecular weight of edestin be taken as 14,500 , or twice the simplest molecular weight as determined by direct analysis (i.e., from C . H. N . S and O content), then the amount of hydrochloric acid combined in the insoluble portion would correspond to a monohydrochloride, whereas that in the soluble portion would correspond to a dihydrochloride. The ordinary edestin preparations are, therefore, usually mixtures of chlorides, containing, however, a certain quantity of sulphate. The relative amounts of these salts depend on the relative amounts of chloride and sulphate present in the liquids used either in the original extractions or in the recrystallisations.

It is of interest to note that all the edestin preparations, whether - free base, sulphate or chloride, have the same crystalline form. The protein part of the molecule is so large in comparison with that of the combined acid that the latter exerts no influence on the form of the crystals. Analogous instances of isomorphism are known in the case of certain minerals, and also in the case of hæmoglobin and its derivatives (e.g., $\mathrm{O}$ and $\mathrm{CO}$ hæmoglobin). In the above-mentioned experiments the method of direct neutralisation was employed (method B I.); another series was carried out with the object of determining the amount of the free base edestin (which is insoluble in water) which is soluble in acids of given strength (method B II.). 
An edestin preparation, almost neutral to phenol phthalein, was obtained by allowing the crystals to separate from a sodium chloride solution containing sufficient sodium hydroxide solution to neutralise the acid ; the amount necessary was determined by the titration of a small aliquot part of the salt solution in the presence of phenolphthalein. ${ }^{1}$ Portions, each of a gram, of this preparation were suspended in 20 c.c. of liquid containing quantities of $\frac{\mathrm{N}}{\mathrm{IOO}}$ hydrochloric acid varying from 2-I4 C.C., in a series of stoppered bottles. After shaking for two hours, and allowing suspended matter to settle, ro c.c. of clear liquid were decanted off, and the amount of edestin in the solution was estimated; the acid contents of the solution and residue were also determined, and the distribution of the acid between the dissolved and undissolved edestin thereby ascertained. Similar experiments were carried out with other acids and also with alkalis. The results obtained by this method of experiment may be briefly summarised as follows :-

(I) The free base edestin, if suspended in water, requires somewhat more than that amount of acid to dissolve it than is necessary to form a dihydrochloride, on the assumption that edestin has the molecular weight 14,500 . If the acid be added little by little to the suspension practically no solution takes place till more than half this quantity has been added; the insoluble monohydrochloride is first formed. Somewhat more than the theoretical amount of acid is necessary to produce complete solution owing to the formation of a more basic hydrolysis product being formed, which is insoluble in water (edestan).

(2) The sulphates of edestin are less soluble than the chlorides, and the existence of definite compounds has not been ascertained; ten times more sulphuric acid than hydrochloric acid is necessary to dissolve a given quantity of edestin. Acetic acid, on the other hand, dissolves nearly the theoretical amount ( $2 \mathrm{~mol}$. acid: I mol. edestin), as in this case little of the basic bye-product is formed. Phosphoric acid acts as a monobasic acid, giving salts of the type $\mathrm{B}^{\prime} \cdot \mathrm{H}_{2} \mathrm{PO}_{4}$ and $\mathrm{B}^{\prime \prime}\left(\mathrm{H}_{2} \mathrm{PO}_{4}\right)_{2}$.

(3) In addition to acting as a base, edestin can also act as an acid; for solution of a given quantity of edestin one molecular equivalent of sodium or potassium hydroxide to one molecular equivalent of edestin is necessary; the solutions of the sodium and potassium salts readily become turbid, owing apparently to hydrolysis. Relatively larger quantities of the carbonates and of ammonium hydroxide are necessary to bring about solution.

With reference to edestin, the chief points of interest are that the existence of definite salts both with acids and bases can be ascertained; with hydrochloric acid both a mono- and dihydrochloride can be prepared, of which the latter only is soluble in water; this latter salt as well as the sodium and potassium edestin compounds have a peculiarity, viz., they are insoluble in the presence of minute quantities of a neutral salt, although they dissolve in more concentrated solutions; in such solutions they show the ordinary property of globulins.

${ }^{1}$ Full details of the preparation of the free edestin are given in the original paper. 
Many similar results with, however, some marked contrast, have been obtained by Hardy in his investigation on serum-globulin; these analogies and contrast will be referred to later.

\section{The Salt Formation of Caseinogen (Lacqueur and Sackur).}

W. A. Osborne showed that the salts of caseinogen could be divided into two classes, viz., those of the alkaline earths and those of the alkalis, which can be distinguished from one another by the facts that the former form opalescent solutions and cannot be filtered through a Martin gelatin filter, whilst the latter form quite clear solutions and can be filtered through gelatin. Osborne clearly recognised the acid character of caseinogen and its salt-forming capacity.

Various attempts have been made to determine quantitatively the amount of different bases necessary to neutralise a given amount of caseinogen, ${ }^{1}$ but the most accurate determinations are due to Lacqueur and Sackur. They showed that the discrepancies of the different observers are due to the fact that the calculations as to combining weights are made with reference to the air-dried caseinogen, instead of the substance dried at $110^{\circ} \mathrm{C}$. This is important when it is remembered that caseinogen preparations are somewhat hygroscopic.

Lacqueur and Sackur confirmed other investigators in their statement of the fact that solutions of caseinogen in alkali, which are alkaline to litmus, are acid to phenol phthalein. They showed furthermore that with phenol phthalein perfectly sharp neutralisation points could be obtained with various alkalis, both by direct titration and by the addition of alkali in excess, and subsequent titration of this excess with acids. They found as a means of several concordant experiments that I gram of caseinogen (calculated as free from water) was capable of neutralising $8.8 \mathrm{I}$ c.c. of $\frac{\mathrm{N}}{\mathrm{IO}}$ sodium hydroxide solution. The amount of water in each sample titrated was estimated by drying at $110^{\circ} \mathrm{C}$; ; the percentages of water were found to vary between $8^{\circ} 2$ and $15^{\circ} 5^{\circ}$.

Lacqueur and Sackur also determined the electrolytic conductivity of solutions of caseinogen, which has been neutralised by sodium hydroxide in the presence of phenol phthalein in various dilutions, with a view of ascertaining the basicity of the acid caseinogen, as Ostwald and Walden have shown that the more polybasic an acid is, the greater is the decrease in the amount of dissociation when the solution of its sodium salt is concentrated. This dissociation influences, of course, the conductivity, and if $\Lambda_{1}$ represent the equivalent conductivity at dilution $v_{1}$ and $\Lambda_{2}$, the equivalent conductivity at dilution $v_{2}$, then between dilutions 32 and 5 I2 (i.e., I gram equivalent in 32 litres and I gram equivalent in 5 I 2 litres) $\frac{\Lambda_{1}-\Lambda_{2}}{\Lambda_{1}}$ has the following average values: for dibasic acids 0.15 , for tribasic acids $0^{*} 22$, for tetrabasic acids $0^{*} 29$, for pentabasic acids 0.35 , and for hexabasic acids 0.39 .

'The reference to these earlier investigations is given in Lacqueur and Sackur's paper. 
Lacqueur and Sackur added to $\frac{\mathrm{N}}{2 \mathrm{O}}$ sodium hydroxide solutions the calculated quantities of caseinogen necessary to neutralise it (a solution in which $v=20$ was thereby obtained); this was diluted to varying concentrations, and the conductivities determined with the following results :-

$\begin{array}{ccc}\text { Per Cent. Caseinogen. } & v \text { (Dilution). } & \Lambda \text { (Equivalent Conductivity). } \\ 2 \cdot 84 & 40 & 46 \cdot 5 \\ \mathrm{r} \cdot 42 & 8 \mathrm{o} & 5 \mathrm{I} \cdot 3 \\ 0 \cdot 7 \mathrm{I} & 160 & 56^{\circ} \cdot 2 \\ 0 \cdot 355 & 320 & 63^{\circ} \\ 0 \cdot 1775 & 640 & 69 \cdot 5\end{array}$

Whence $\frac{\Lambda_{640}-\Lambda_{40}}{\Lambda_{640}}=0.33$.

From this it follows that caseinogen is at least a tetrabasic acid. Now as I gram neutralises 8.8 I c.c. $\frac{\mathrm{N}}{\mathrm{IO}}$ sodium hydroxide, its equivalent combining weight is $\frac{1000}{0.88 \mathrm{I}}=\mathrm{I} \mathrm{I} 35$. On the assumption that caseinogen is a tetrabasic acid its molecular weight would be 4540 , or, on the assumption that it is hexabasic, 68 IO.

The sodium salts of caseinogen can, like other protein salts, undergo hydrolysis in solution. The solution of caseinogenate of sodium, which is obtained by just neutralising caseinogen with sodium hydroxide, is slightly opalescent and the opalescence disappears on addition of excess of alkali. Furthermore, the point of neutralisation, when litmus is employed as indicator, varies very appreciably with the dilution of the solution. The condition of equilibrium may be represented by the equation

$$
\text { Kas. } \mathrm{nNa}+\mathrm{nH}_{2} \mathrm{O} \leftrightarrows \text { Kas. } \mathrm{nH}+\mathrm{nNaOH} ;
$$

or possibly acid salts may be formed-

$$
\text { Kas. } \mathrm{nNa}+\mathrm{mH}_{2} \mathrm{O} \leftrightarrows \mathrm{Kas}(\mathrm{n}-\mathrm{m}) \mathrm{Na}+\mathrm{mNaOH}
$$

\section{(cf. Hardy ${ }^{1}$ on serum-globulin).}

The statements with regard to hydrolysis have been confirmed by Lacqueur and Sackur by the measurement of the internal friction of sodium caseinogenate solutions. The magnitude of the internal friction depends chiefly on the concentration of the caseinogen ions; very small quantities of free acid diminish the friction (thus setting free caseinogen from its salts), whilst correspondingly small quantities of alkali increase it.

\section{The Salt Formation of Serum-Globulin (Hardy).}

To determine the combining powers of acids and bases with serumglobulin Hardy employed two of the chemical methods (B I. and B II.), viz., direct titration and determination of the amount of globulin (which is insoluble in pure water) soluble in given quantities of acids and bases.

By the second of the two methods the more accurate results were obtained. Various acids of the concentration $0.005 \mathrm{~N}$ were added to suspensions of globulins containing from $0^{\circ} 28$ to $4^{\cdot} \cdot 8$ grams in 
roo c.c. The acid was in each case added gradually until the mixture was only slightly opalescent and matched a given standard. The amount of acid necessary to produce this given degree of opalescence was thereby determined. A large number of determinations at different temperatures were carried out. If the mean amount of hydrochloric acid necessary to produce this grade of solution of I gram of globulin be taken as unity, the relative amounts of other acids (given in equivalents) necessary to produce the same result is given in the following table :-

\begin{tabular}{|c|c|c|c|c|}
\hline \multicolumn{2}{|l|}{ Monobasic Acids. } & Dibasic Acids. & \multicolumn{2}{|c|}{ Tribasic Acids. } \\
\hline $\mathrm{HCl}$ & $I \cdot O$ & $\mathrm{H}_{2} \mathrm{SO}_{4}$ & Citric acid & $3 \cdot 0$ \\
\hline $\mathrm{HNO}_{3}$ & 0.995 & Tartaric acid I.994 & $\mathrm{H}_{3} \mathrm{PO}_{4}$ & \\
\hline $\mathrm{CHCl}_{2} \cdot \mathrm{COOH}$ & $I \cdot 0$ & Oxalic acid $\quad r \cdot 9$ & $\mathrm{H}_{3} \mathrm{BO}_{3}^{2}$ & Very large excess \\
\hline $\begin{array}{l}\mathrm{CCl}_{3} \cdot \mathrm{COOH} \\
\mathrm{CH}_{2} \mathrm{Cl} \cdot \mathrm{COOH}\end{array}$ & $r \cdot 0$ & & & \\
\hline $\begin{array}{l}\mathrm{CH}_{2} \mathrm{Cl} . \mathrm{COOH} \\
\mathrm{H} . \mathrm{COOH}\end{array}$ & $\begin{array}{l}I .05 \\
x \cdot 25\end{array}$ & & & \\
\hline $\begin{array}{l}\mathrm{CH}_{3} \cdot \mathrm{COOH} \\
\mathrm{CH}_{2} \cdot \mathrm{CH}_{3} \cdot \mathrm{COOH}\end{array}$ & $\begin{array}{l}5 \cdot 2 \\
7 \cdot 56\end{array}$ & & & \\
\hline
\end{tabular}

It will be noticed here that the solvent power of strong acids is a molecular function, and that $\mathrm{HCl}=\mathrm{H}_{2} \mathrm{SO}_{4}=\mathrm{H}_{3} \mathrm{PO}_{4}$. It may be recalled that Osborne, in the case of edestin, also observed that $\mathrm{HCl}=\mathrm{H}_{3} \mathrm{PO}_{4}$, and that salts of the type $\mathrm{B} . \mathrm{H}_{3} \mathrm{PO}_{4}$ are obtained. The weaker acids require relatively far larger quantities to produce the same grade of solution; this is due to the readiness with which salts undergo hydrolysis in dilute solutions.

Generally the results obtained indicate that serum-globulin forms salts of the same type as the amino-acids, i.e., salts in which a molecule of acid and base combine to form additive compounds without replacement :-<smiles>NCC(=O)O</smiles>

Similar experiments were carried out with bases. Taking $\mathrm{NaOH}$ as unity, the relative solvent actions may be represented by the following figures :-

$\begin{array}{ll}\mathrm{KOH} & \text { I } \\ \mathrm{NaOH} & \mathrm{I} \\ \mathrm{NH}_{4} \cdot \mathrm{OH} & 0.98 \\ \mathrm{Ba}(\mathrm{OH})_{2} & 2 \cdot 008\end{array}$

Urea and aniline also dissolve serum-globulin, but the quantitative relationships were not determined. One point of considerable interest appears from these numbers, viz., ammonia, which is a weak base, has practically the same solvent power as sodium and potassium hydroxides. Now the weak acids like acetic acid have considerably less solvent power than the strong mineral acids, and these facts indicate that serum-globulin has more decidedly marked acidic than basic functions. In this respect it differs markedly from the plant globulin edestin.

In respect to its action on bases, the behaviour of globulin is somewhat peculiar in that I molecule of sodium hydroxide is equivalent to I molecule of barium hydroxide.

Measurements of the acidity and basicity of globulin by titration in presence of indicators were also carried out. Freshly precipitated and washed globulin reacts as acid to dialysed litmus, gives no colour 
with phenol phthalein, and only slightly depresses the orange tint of methyl orange. Such a reaction might be due to the carbonic acid held in combination by the protein.

On titration with alkalis in the presence of phenol phthalein certain marked phenomena were observed. It was noticed that just half as much sodium hydroxide or potassium hydroxide was necessary to produce solution as was necessary to produce a permanent red solution; in the case of barium hydroxide, on the other hand, the point of solution and the point of neutralisation to phenol phthalein coincided. These facts suggest that globulin has two replaceable hydrogens, and can form acid salts, of which those of sodium and potassium are soluble, and that of barium insoluble. The same relative amount of ammonia as of sodium and potassium hydroxide is necessary to produce solution; as might be expected, however, the neutralisation point with phenol phthalein is somewhat indeterminate. It was found, as a general result of the neutralisation method, that $10 \times 10^{-5}$ equivalents of alkali were necessary for the solution of I gram of globulin, and $20 \times 10^{-5}$ were necessary for neutralisation with phenol phthalein as indicator; $20 \times 10^{-5}$ equivalents of strong acids were also necessary to produce solution.

It is of interest to compare those numbers with the numbers obtained by Hardy for dialysed acid and alkali albumin from eggwhite:-

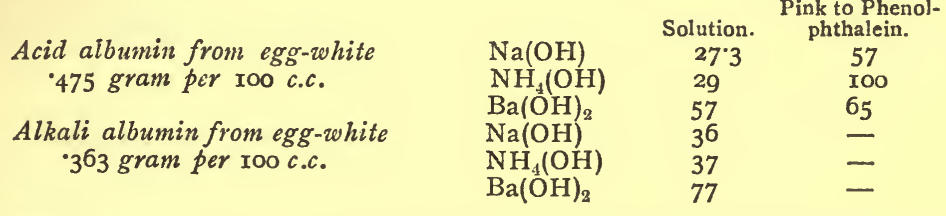

Here again the molecular and not the equivalent quantities of base exert the same solvent action, and there is evidence of the formation of acid and basic salts.

Further investigations were made as to the acid and basic functions of serum-globulin by the employment of physical methods.

By means of conductivity methods the basicity of globulin was determined. The value $\frac{\Lambda_{1}-\Lambda_{2}}{\Lambda_{1}}$ (see Lacqueur and Sackur's work above, p. 50) between $v=32$ and $v=32 \times 32$ was determined; as a result, it was concluded that globulin is pentabasic.

The hydrolysis of both the acid and basic salts was determined by ascertaining the rate of inversion of cane-sugar, and of hydrolysis of methylacetate by acids and bases in the presence of globulin salts. Owing to the change of the latter in the presence of acids, no very conclusive results were obtained as to the hydrolysis of the acid salts. The results, such as they were, indicated under the conditions of experiments a distinct amount of hydrolysis :-

$$
\text { Glob. } \mathrm{HCl}+\mathrm{H}_{2} \mathrm{O}=\text { Glob. } \mathrm{OH}+\mathrm{HCl} \text {. }
$$

With alkalis, under similar conditions, but little hydrolysis was indicated. With a concentration of $25 \% 6$ grams of globulin in a litre neutralised by $17^{\circ} 12 \times 10^{-5}$ equivalents of $\mathrm{NaOH}$ for each gram of globulin, the hydrolysis, as indicated by methylacetate catalysis, was only $0^{\circ} 288$ per cent., i.e., only 0.288 per cent. of the 
sodium globulin compound was hydrolysed by water under the conditions of the experiments.

Measurements were also made of the conductivities of the different salts in gradually increasing concentrations. It was found that in the case of the hydrochloride the molecular conductivity increases much more for increase of volume than does the conductivity in the case of the sodium hydroxide compound. This is due to the fact that the acid functions of globulin are far more marked than its basic functions, for from the equation

$$
\mathrm{M}_{\gamma}=(\mathrm{x}-x) \mu_{\gamma}+x \mu_{\mathrm{HCl}} \text { or } \mathrm{NaOH},
$$

where $\mathrm{M}_{\gamma}$ is the total conductivity, $x$ the fraction of the salt hydrolysed, $\mu_{y}$ the conductivity of the non-hydrolysed salt, and $\mu_{\mathrm{HCl} \text { or NaOH}}$ the conductivity of the salt or acid, when $\mu_{\mathrm{HCl} \text { or } \mathrm{NaOH}}$ is greater than $\mu_{\gamma}$ (as is the case with the globulin salts), the more $x$ increases with dilution the greater $\mathrm{M}_{\gamma}$ must become. In the case of the sodium hydroxide compound of globulin the increase of conductivity with dilution is not markedly greater than it is in the case of the inorganic salts mono- and disodium-hydrogen phosphates; there is little evidence of hydrolysis. In the case of the hydrochloride the conductivity determinations indicate marked hydrolysis.

Determinations were also made of the ratios of the conductivities of solutions of various acids and salts, both alone and after saturation with globulin. In the case of very weak acids, such as boracic acid, when a large amount of hydrolysis would be expected from the equation

$$
\mathrm{M}_{\gamma}=(\mathrm{I}-x) \mu_{\gamma}+x \mu_{\text {acid }},
$$

$\mathrm{M}_{\gamma}$ would be nearly equal to $\mu_{\text {acid. }}$ This is as a matter of fact the case, for $\frac{\mu_{\text {salt }}}{\mu_{\text {boracic acid }}}=0.9$. In the case of hydrochloric acid, where the amount of hydrolysis is comparatively small, the value $\frac{\mu_{\text {salt }}}{\mu_{\text {acid }}}$ is $0^{\circ} 24$. In the case of ammonia, the free base conducts but little; in fact, distinctly less than the salt formed by the combination of globulin and ammonia, and the value $\frac{\mu_{\text {salt }}}{\mu_{\text {ammonia }}}$ is 2.3 .

All these facts lead to the conclusion that globulin forms with alkalis salts which readily undergo ionisation and are good conductors, but which, in contradistinction to the acid salts, are hydrolysed but little with water.

These salts of serum-globulin have certain characteristic properties which are not shared with ordinary salts. It has already been mentioned that the solubility of globulin in acids was determined by adding acids to a suspension until a definite grade of solution was reached, which in most cases was that of minimal opalescence (a process described by Hardy as that of matching). Conversely, if such a solution be dialysed against distilled water, acid passes out, and the globulin solution becomes more and more opaque, without the separation at any time of a solid phase. Such an action Hardy ascribes to hydrolysis and the formation of basic salts, which would take place according to the equation

$$
x \mathrm{GHAc}+y \mathrm{HOH}=(\mathrm{GHOH})_{y}(\mathrm{GHAc})_{x-y}+y \mathrm{HAc},
$$

where $G$ represents globulin and Ac acid. 
With bases (B) a similar reaction would take place-

$$
x \mathrm{~GB}+y \mathrm{HOH}=(\mathrm{GH})_{y}(\mathrm{~GB})_{x-y}+y \mathrm{BOH} .
$$

With increase in the value $y / x$, the size of the molecules of the globulin salt molecules would increase until finally they are large enough to diffract white light. Such molecules take part in electric transport, and their velocity, as measured indirectly by conductivity and by the "boundary" method, is exceptionally high, much higher, in fact, than, according to Ostwald's law, could be accounted for by ions containing such a large number of atoms. When large molecules, such as the globulin salts, become ionised and take part in electrical transport, they are said, according to Hardy, to form " pseudoions," and when the magnitude of these latter become sufficiently large, they attain the properties of matter in mass, being defined by a surface, and moving under the influence of a surface contact difference of potential.

Somewhat similar to the phenomena just mentioned is the formation of opalescent solutions of caseinogen salts. In spite of these peculiarities there is considerable evidence of a true chemical reaction between serum-globulin and acids and bases. It is also possible that globulin forms compounds with salts of the type $\mathrm{GNaCl}$, which readily hydrolyse with water. This would account for the fact that such compounds are only stable in the presence of a large excess of salt, i.e., they are soluble only in comparatively concentrated salt solutions, from which they are reprecipitated on dilution. A globulin acid salt is also but slightly soluble in dilute salt solutions, owing to the double decomposition-

$$
\mathrm{GHAc}+\mathrm{NaCl}=\mathrm{GNaCl}+\mathrm{HAc} .
$$

The globulin alkali salts, however, are more readily soluble in salt solutions than simple globulin. This Hardy considers to be due to the compounds in question being of the following types :-<smiles>[R]C(=O)NC(Cl)Cl</smiles><smiles>[R]C(=O)NCCNCCl</smiles>

for the compounds of acids and salts. The one could only be formed from the other by double decomposition. The compounds with bases would be formed by the replacement of the hydrogen in the carboxyl group.

The above chemical considerations go far to explain the peculiar solubility conditions of the globulin type of proteins.

\section{The Question of Pseudo-acid and Pseudo-base Formation.}

Cohnheim has expressed the opinion that proteins may belong to that class which Hantzsch has termed pseudo-acids and pseudo-bases. Of such a class typical examples are the nitro-paraffins, e.g., nitroethane. This body can exist in the two forms-

$$
\begin{aligned}
& \mathrm{CH}_{3} \cdot \mathrm{CH}_{2} \cdot \mathrm{NO}_{2} \quad \text { True nitro-form which is a neutral body. } \\
& \mathrm{CH}_{3} \cdot \mathrm{CH}^{\mathrm{N}} \mathrm{NO} . \mathrm{OH} \text { Pseudo nitro-form which is an acid body. }
\end{aligned}
$$

In the presence of alkali the true nitro-form is slowly converted into the pseudo-form-

$$
\mathrm{CH}_{3} \cdot \mathrm{CH}_{2} \cdot \mathrm{NO}_{2}+\mathrm{NaOH}=\mathrm{CH}_{3} \cdot \mathrm{CH}: \mathrm{NO} \cdot \mathrm{ONa}+\mathrm{H}_{2} \mathrm{O} .
$$


If the sodium salt thus obtained be acidified it is reconverted into the free acid and sodium chloride-

$$
\mathrm{CH}_{3} \cdot \mathrm{CH}: \mathrm{NO} \cdot \mathrm{ONa}+\mathrm{HCl}=\mathrm{CH}_{3} \cdot \mathrm{CH}: \mathrm{NO} \cdot \mathrm{OH}+\mathrm{NaCl} \text {. }
$$

Such a solution has at first the electrolytic conductivity of the acid pseudo-form + that of sodium chloride. After a time, however, the pseudo-form gradually reverts to the true nitro-form, the conductivity diminishes, and the solution attains finally the conductivity due to sodium chloride alone. In a like manner the neutralisation of the true nitro-body does not take place immediately, but there is a certain latent period. The higher the temperature the shorter is this period. Similarly certain pseudo-bases have been shown to exist, and both are characterised by this latent period of neutralisation. The conductivity changes, moreover, when neutralisation takes place, are characterised by a high temperature coefficient, owing to the influence of the increased temperature on the rate of change.

Neither the latent period of neutralisation nor the high temperature coefficient for the conductivity has been observed by Hardy in his investigations on the serum-globulin, and he comes to the conclusion that the hypothesis of Cohnheim that proteins act as pseudo-acids and pseudo-bases is not justified by experimental facts. Similar conclusions have also been arrived at by a different experimental method by von Rhorer.

In concluding this section, emphasis must be laid upon the anomalous behaviour in many respects of the proteins on treatment with acids and bases. This behaviour is probably to be ascribed to their capacity as colloids to adsorb inorganic substances, to which reference has been already made in the introduction. This fact renders it often impossible to discriminate between physical adsorption and chemical combination, and for this reason some of the conclusions recorded above must be accepted with reserve.

\section{Section XVII.-The Precipitation of Proteins by Salts of the Heavy Metals.}

It has already been mentioned that the addition of salts of the heavy metals, such as those of copper, mercury and lead, to protein solutions produce precipitates. Numerous attempts have been made to determine the composition of such precipitates and to isolate definite protein salts of the heavy metals. There is a large literature on the subject, and the various investigators have arrived at results which are by no means concordant. The precipitates, which have received the largest amount of investigation, are those produced by the addition of copper salts. Certain of the products isolated have a relatively large copper content, as the following analyses, due to Ritthausen, of vegetable protein precipitates show :-

\begin{tabular}{|c|c|c|}
\hline "Gluten-caseinogen" $f$ & $\begin{array}{l}\text { U. } \\
\text { I6.97 }\end{array}$ & Ash. \\
\hline Legumin frc & 15.61 & $I \cdot 2 I$ \\
\hline ad beans & I4. Io & 3.05 \\
\hline ", from oats & $\begin{array}{c}\text { I3.53 } \\
\text { I3.38-II.60 }\end{array}$ & - \\
\hline
\end{tabular}

The copper precipitate obtained from milk caseinogen also shows a high copper content-I $2^{\circ} 7$ to $13^{\circ} 6$ per cent., according to the analyses of Ritthausen and Pott.

Very widely differing results have been obtained by analyses of 
the precipitate obtained by adding copper salts to a solution of eggwhite. Harnack, by precipitating in the presence of excess of protein, obtained a precipitate containing $\mathrm{I} \cdot 35$ per cent. $\mathrm{Cu}$; when, however, he precipitated in presence of excess of the copper salt, he obtained a product containing $2 \cdot 64$ per cent. $\mathrm{Cu}$. Other investigators have obtained products in which the percentage of copper varied between 0.7 and 4.15 per cent. Equally unsatisfactory and variable are the results obtained by the precipitation with salts of other heavy metals. ${ }^{1}$

The formation of the precipitates in question has more recently formed the subject of investigations by Galeotti and by Pauli, who have called attention to the complexity of the question.

Galeotti noticed that if a 3 per cent. albumin solution be allowed to fall, drop by drop, into an $\frac{\mathrm{N}}{\mathrm{IO}}$ copper sulphate solution, a thick precipitate first forms, which redissolves on the addition of an excess of protein, so that finally a homogeneous solution is obtained. If more copper sulphate be added to this clear solution a precipitate is formed again, which will redissolve on addition of excess of protein. If an albumin solution be added, drop by drop, to a concentrated copper solution, a precipitate will form as the drops first enter the salt solution, but will disappear on shaking; on addition of more albumin a precipitate continues to be formed, which dissolves less and less readily after each addition, until finally it becomes permanent. If, on the other hand, concentrated copper sulphate be added to a protein solution a precipitate is formed, which gradually dissolves on the addition of excess of the salt, giving a clear green solution which contains protein in large quantities.

Silver salts behave in a somewhat different way. If an albumin solution be allowed to drop into a I per cent. silver nitrate solution a flocculent precipitate forms, which redissolves in an excess of protein. If, on the other hand, a solution of silver nitrate be allowed to fall into an albumin solution, no precipitate forms until a certain definite quantity of the salt has been added; at this point a precipitate commences to form, which increases in quantity with each additional drop of the salt. If albumin be added again, the precipitate redissolves.

Galeotti draws from his investigations the following conclusions : I. Proteins form no definite compounds of ' constant composition with salts of the heavy metals; the precipitates which form when protein solutions and solutions of salts of the heavy metals are mixed are simply loose compounds, the composition of which depends on the conditions of precipitation. II. The precipitation phenomena are often reversible, ${ }^{2}$ in the sense that the precipitates are soluble in excess of either reagent. III. The composition of the precipitate depends on the composition of the supernatant liquid and is determined by the thermodynamical laws of chemical equilibrium. IV. For the system albumin (egg or serum), water and salt

\footnotetext{
${ }^{1}$ A table of these results is given in Galeotti's paper. References to the earlier literature are given in Harnack's paper.

${ }^{2}$ Galeotti uses the expression reversible, but only in the sense described in the text, i.e., solubility on adding excess of either reagent. The reversibility is to be distinguished from that of the precipitation by, e.g., salts of alkalis, where the precipitates redissolve on addition of water.
} 
(copper sulphate or silver nitrate), it is possible to solve the problem of chemical equilibrium by a graphical method, and, given the percentage composition of a complex, to determine into how many phases it will separate, and the composition of each phase.

Pauli has investigated in some detail the conditions of precipitation by zinc sulphate. He found that there were two maxima of precipitation when this salt was added to an egg-protein solution of a certain strength. The precipitating power increased gradually between concentrations corresponding to $\mathrm{OOI}$ to $0^{\circ} \mathrm{O} 5$ normal. From this point the precipitating power gradually decreased, until the concentration corresponding to that of a normal solution was reached. From this point onwards till the concentration $2 \mathrm{~N}$ was attained, no precipitation whatever took place. On increasing the concentration beyond this point, however, precipitation recommenced, and increased with increasing strength of the salt solution until a second maximum was attained. The precipitates obtained with the lower dilution were irreversible, that is to say, they would not redissolve on addition of water; those obtained at the higher dilution were, on the other hand, reversible and redissolved on dilution of the supernatant fluid. The numbers just given refer only to solutions containing a definite amount of egg-protein. In this particular case the limits between which the maximum formation of the irreversible precipitate and the incipient formation of the reversible precipitate took place were 0.05 and $2 \mathrm{~N}$. These limits are wider with a lower protein concentration and narrower with a higher concentration.

These examples are sufficient to indicate the extremely complex conditions governing the composition of the precipitates produced when solutions of the salts of heavy metals are added to protein solutions. In the majority of cases compounds of definite chemical composition cannot be isolated. This statement does not, however, preclude the possibility that certain proteins of more acidic character, such as caseinogen, should form salts of definite chemical composition, and further investigation of precipitates with high copper content, such as those derived from plant proteins and caseinogen, seems desirable.

Various theories have been advanced to account for the nature of the precipitates produced by salt precipitation. These have been summarised in the paper of Pauli referred to. They may be more fittingly discussed in dealing with the general chemical physics of colloidal solutions and the theory of salt precipitation of colloids. In the present state of knowledge the precipitates produced by the salts of the heavy metals cannot be regarded as of sufficiently definite chemical nature as to make them of value in fixing the characters of the protein from which they are derived, and for this reason they have been treated in a somewhat cursory manner.

\section{Section XVIII.-The Oxidation of the Proteins.}

In recent years the chemical examination of proteins, with a view to elucidation of the constitution, has been confined chiefly to the study of the hydrolysis products. This method, apart from the value of the results yielded, is a logical one, in view of the fact that all evidence with regard to the biological utilisation points to the fact that the first stage of protein degradation is one of hydrolysis. 
Nevertheless several investigations on the direct oxidation of proteins without previous hydrolysis deserve mention.

\section{Oxidation with Permanganate.}

The oxidation with permanganate solution has been the subject of repeated studies. ${ }^{1}$ The chief investigations are due to Maly and von Fürth. Other investigators were Bechamp, Sabbotin, Pott, Brücke, Chandelon, Löw, Siegfried, Bondzynski and Zoja, Bernert and Ehrmann.

Maly, under the name of oxyprotosulphonic acid, described a product which he obtained by oxidising egg-white with half its weight of potassium permanganate in the cold. Under the name of peroxyproteic acid he described a product which was obtained by slowly adding small portions of permanganate to a protein solution, at room temperature, until only very slow oxidation took place. This acid, isolated by precipitation with salts of heavy metals (mercury, lead, etc.), gave a marked biuret reaction, but was not precipitated by the ordinary alkaloidal reagents. On gentle treatment with baryta water a large amount of ammonia was evolved, and separation of oxalic acid in the form of its barium salt took place. By continued hydrolysis with baryta, lasting for several days, glutamic acid, leucine, formic, acetic and benzoic acids were obtained.

Further investigations on the oxyprotosulphonic acid from eggwhite were carried out by Bernert and Ehrmann.

The most complete of the recent investigations on the permanganate oxidation products are due to von Fürth. He oxidised caseinogen with four times its weight of potassium permanganate at room temperature, the reaction taking several weeks to complete. A product was obtained which was resistant to further action of the oxidising reagent. This was shown to consist of at least three products of high molecular weight, which gave the biuret reaction, but not the Millon, xanthoproteic or Hopkins reactions, and which could be separated by fractional precipitation with silver nitrate (A), lead acetate (B), and mercuric acetate (C). From the three peroxyproteic acids thus obtained, the esters could be readily prepared by means of alcoholic hydrochloric acid. On treating these acids with barium hydroxide a scission took place of oxalic acid, in the form of its barium salt; there was also a considerable loss of nitrogen. The substances obtained in this way were designated by von Fürth as desamino-proteic acids, and they yielded on hydrolysis glutamic acid, leucine, benzoic acid and ammonia. Unlike the oxyproteic acids, from which they were derived, they were no longer resistant to further oxidation with permanganate; the scission of the oxalic groups had left a new position of weakness in the molecule, and the desamino-acids readily oxidised on further addition of the oxidising agent, yielding a mixture of substances of a new class called the kyroproteic acids, which gave a marked biuret reaction. By means of lead acetate, these could be separated into acids which contain a large quantity of oxygen, which could be readily oxidised further. The kyroproteic acids, furthermore, on treatment with nitrous acid, readily lose half their nitrogen, relatively five times as much as is lost by caseinogen by similar treatment.

\footnotetext{
${ }^{1}$ A succinct account of the earlier literature is given in von Fürth's paper, rgo5.
} 
There is not sufficient experimental material to draw any very definite conclusions as to the course of oxidation of the proteins, but some suggestions of Hofmeister seem reasonable. If the typical polypeptide grouping of a protein be represented as follows-

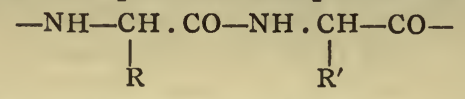

the first stage of the oxidation would be-<smiles>CNC(C(=O)O)C(=O)NC(C(C)=O)C(=O)O</smiles>

from which, by $\mathrm{CO}_{2}$ scission, the grouping

$$
-\mathrm{NH}-\mathrm{CH}_{2} \text {. } \mathrm{CO}-\mathrm{NH} . \mathrm{CH}_{2} \text {. } \mathrm{CO}-
$$

would be formed, which on further oxidation would yield a group

$$
\text { -NH.CO. CO-NH.CO.CO- }
$$

From such a group, by hydrolysis, oxalic acid and ammonia would be obtainable. It is of interest to note that Zickgraf, Seemann, and Kutscher and Schenck have obtained by the oxidation of proteins oxaluramide-

$$
\stackrel{\mathrm{CO}}{\mathrm{CO} . \mathrm{NH}_{2} \mathrm{NH}_{2}}>\mathrm{NH}
$$

which contains the complex $-\mathrm{NH}-\mathrm{CO}-\mathrm{CO}-\mathrm{NH}-$

The hypothesis is, however, insufficient to explain all the facts connected with the oxidation, as the amount of amide nitrogen, which can be eliminated with nitrous acid, does not correspond with the amount of oxalic acid.

\section{Oxidation with Hydrogen Peroxide and Ozone.}

The oxidation of proteins by hydrogen peroxide has been studied by Wurster and by F. N. Schulz, and the action of ozone has been studied by v. Gorup-Besanez and Harries and his pupils. Wurster and Schulz noticed that egg-albumin (Wurster used egg-white solution and Schulz the crystallised product) on standing with excess of hydrogen peroxide in neutral solution at $37^{\circ} \mathrm{C}$. deposited after a time the protein in an insoluble form. The product thus obtained was subjected to a detailed examination by Schulz, who found that it did not differ very greatly from the original protein in its percentage composition. The ratio of hydrogen, carbon and nitrogen was practically unchanged, but it contained about 2.6 per cent. more oxygen. Schulz designated this substance-oxyprotein, and he showed that, unlike the oxyproteic acids, it yielded the ordinary protein reactions. It represents, therefore, a simple oxidation product.

Blumenthal and Neuberg have shown that gelatin, in the presence of an iron or copper salt, yields, on oxidation with hydrogen peroxide, acetone. The same product has been obtained by Orgler from egg-albumin, using the same method.

The action of ozone on caseinogen has recently formed the subject of an extensive research by Harries and Langheld. By prolonged action of ozone on the sodium salt considerable chemical change took place. A product was obtained which gave a marked biuret reaction, but no reaction with the xanthoproteic, Millon or Hopkins reagents ( $c f$. oxyproteic acids). It gave a precipitate with 
phenylhydrazine, indicating the presence of aldehydic and ketonic groups, and could be separated into three fractions by means of phosphotungstic acid and lead acetate. This operation was carried out as follows: the original product was precipitated by phosphotungstic acid (in the presence of sulphuric acid); to the substance, regenerated by barium hydroxide from this precipitate, lead acetate was added, and the greater part precipitated (fraction A); the filtrate from the lead precipitate formed the second fraction ( $B$, i.e., the fraction precipitable by phosphotungstic acid, but not by lead acetate); from the filtrate from the phosphotungstic precipitate a third fraction was obtained $(\mathrm{C})$, which was not precipitable with lead acetate. These three fractions were hydrolysed by Emil Fischer's method, but no very essential difference between them could be detected. Fraction C yielded, however, practically no leucine, whereas fractions $\mathrm{A}$ and $\mathrm{B}$ did. The other amino-acids obtained by hydrolysis were alanine, valine, aspartic and glutamic acids. Glycine and proline could not be isolated. It is noteworthy, furthermore, that tyrosine, phenylalanine and tryptophane appeared to be absent; it seems probable that ozone had attacked the aromatic groups of the protein molecule.

\section{Action of Nitric Acid.}

The principal product obtained by the oxidation of nitric acid is oxalic acid. On carefully dissolving proteins in nitric acid and afterwards adding water, yellow substances, known as xantho-proteins, can be obtained. These have been investigated by von Fürth (Habilitationsschrift, Strassburg, I899).

\section{Section XIX.-The Action of Halogens on Proteins.}

Investigations on the action of halogens on proteins date back to I848, when Mulder described a "protein chlorous acid," which he obtained as a precipitate when chlorine was passed into a solution of egg-albumin.

Since that date the preparation of halogen derivatives of proteins has been the subject of numerous investigations; owing, however, to the complexity of the possible reactions, and the variations in the composition of the products obtained under different conditions of experiment, the preparation of halogen derivatives has, up to the present, been but little applied to the characterisation of individual proteins ; the composition of the products depends too much on the details of the preparation.

\section{Chlorine Derivatives of Proteins.}

In more recent times the chlorine derivatives have been studied by Rideal and Stewart, Hopkins and Pinkus, Blum and Vaubel, Habermann and Ehrenfeld, and by Panzer. Rideal and Stewart, and Hopkins both confirmed the older observation of Mulder with regard to the formation of a precipitate when chlorine is passed into a protein solution, and the two former investigators proposed to found upon this reaction a method for the quantitative determination of proteins.

Hopkins and Pinkus passed chlorine into a cold protein solution till the latter was saturated, when a thick precipitate suddenly formed; this was purified by solution in a I per cent. sodium hydroxide 
solution, and precipitation from the latter by dilute acetic acid. From egg-albumin (not crystalline) a product containing 3.62 per cent. of chlorine was obtained. By a modification of the method, products containing other quantities of chlorine could be obtained. Thus by chlorinating in the presence of potassium chlorate, dissolving the precipitate thus formed in alcohol, and adding ether to the alcoholic solution, a derivative was obtained which contained $6.4 \mathrm{I}$ per cent. of chlorine. As will be noticed later, a definite series of bromine derivatives could be obtained from proteins, each with a constant amount of bromine, by varying the method of preparation. It was not found possible to obtain such a definite series either with chlorine or iodine preparations.

Blum and Vaubel prepared chlorine preparations from proteins in the presence of sodium hydroxide; they state that it is impossible to obtain products containing the maximum amount of combined chlorine in the presence of free acid, which is formed by the action of halogen on the protein; consequently they carried out the reactions in the presence of sodium hydroxide, which was added from time to time to neutralise the acid as it was formed in the reaction. They obtained from egg-albumin and caseinogen preparations containing 2 per cent. of chlorine.

Habermann and Ehrenfeld prepared a chlorine derivative from caseinogen. They dissolved IOO grams of the protein in 700 c.c. of 5 per cent. potassium hydroxide solution, to which was added 50 grams of potassium chlorate; through this solution hydrogen chloride gas was passed. After completion of the reaction the liquid was filtered off from the potassium chloride formed during the reaction, and diluted with water, whereupon the chloro derivative separated, which contained between 13 and 14 per cent. of halogen.

Panzer also prepared a chlorine derivative of caseinogen. He made a paste of I kilogram of the protein with 4 litres of 20 per cent. hydrochloric acid; to this 450 grams of potassium chlorate were added in small quantities at a time, and considerable evolution of heat took place. After cooling water was added, and the undissolved substance filtered off. This was a chlorine derivative containing about 8.3 per cent. of chlorine-considerably less than that in the preparation which Habermann and Ehrenfeld obtained by a similar method.

\section{Bromine Derivatives of Proteins.}

Some preliminary investigations on the action of bromine on proteins were published by Loew, but most of our knowledge on this subject is due to the investigations of Hopkins and Pinkus. As already mentioned, they obtained different products with definite bromine content by varying the methods of preparation. They obtained three distinct bromine derivatives from egg-albumin. Derivative I. was obtained by treating the protein solution in the cold with bromine until the solution was distinctly coloured; a precipitate (crude bromination product) formed suddenly; this was dissolved in I per cent. sodium hydroxide, from which it was precipitated by the addition of acetic acid. The precipitate was dialysed against water, and then washed with alcohol, in which it is only slightly soluble. It contained 3.92 per cent. of bromine. Derivative II. was prepared by dissolving the crude bromination 
product when still moist in hot alcohol, and allowing the solution to drop into ether ; a product was thereby obtained which was easily soluble in alcohol, and which could be purified by repeated solution in this solvent and reprecipitation with ether. It contained 10.82 per cent. bromine. Derivative III. was prepared by dissolving the moist crude bromination product in alcohol containing bromine, and pouring the solution thus obtained into ether containing bromine. A product resulted which, after washing with ether, contained $14^{\circ} 9$ per cent. of bromine.

These derivatives can be converted one into the other. Thus, for example, by dissolving derivative II. in sodium hydroxide solution, and then adding acetic acid, a product containing only about 4 per cent. bromine can be obtained. Conversely, if derivative I. be added to alcohol containing bromine, and the solution thus obtained be thrown into ether containing bromine, a product is obtained which contains about I 5 per cent. bromine (derivative III.).

Derivatives of the third class, containing the largest percentage of bromine, were prepared from several other proteins. The bromine content of the derivatives thus obtained may be regarded as characteristic for each protein. From varying fractions of eggalbumin substances containing from I2.79-16.48 per cent. halogen were obtained; from serum of different fractions the bromine derivatives contained from I $2^{\circ} \mathrm{I} 5-\mathrm{I} 2^{\circ} 94$ per cent. ; from serum-globulin they contained from 13.53-1 4.03 per cent. The bromine derivative of caseinogen contained II I 7 per cent., that of proto-albumose $16 \cdot 30-$ I $7^{\circ} 12$ per cent., and of deutero-albumose $17^{\circ} 63$ per cent.

It was not found possible to obtain such definite series of derivatives of chlorine or iodine derivatives; nevertheless, evidence was obtained that such series existed, although substances with definite halogen content were not always obtainable. It was not found possible either to obtain iodine derivatives, corresponding to derivative III.

Blum and Vaubel also obtained bromine derivatives of proteins, using the method already mentioned, viz., treating with halogen in slightly alkaline solution; from egg-albumin and caseinogen they obtained products with between 4 and 5 per cent. of bromine.

\section{Iodine Derivatives of Proteins.}

The earlier investigations on the iodine derivatives are due to Böhm and Berg, and Jendrássik. ${ }^{1}$ The two former noticed the decolorisation of iodine by protein solutions, and, by coagulation, isolated a product from which, by dialysis and washing, the iodine could be removed. Jendrássik determined the amount of iodine which could be decolourised by a protein solution. Other investigations were published later by Liebrecht and by Lépinois, who obtained products containing respectively $17^{\circ} 8$ and $21^{\circ} 6$ per cent. iodine, part of which, at any rate, was in stable combination. The chief systematic investigations on the iodine derivatives, apart from the ones on the halogen derivatives generally of Hopkins and Pinkus, and Blum and Vaubel, already mentioned, are those of Hofmeister, Kurajeff and C. H. L. Schmidt.

Hofmeister worked with crystallised egg-albumin. He treated 20 grams dissolved in 400 c.c. water with 1o grams potassium

1 These earlier investigations are discussed in Hofmeister's paper. 
iodide, 5 grams potassium iodate, and 4 c.c. concentrated sulphuric acid for four hours on a water-bath. A brown precipitate was thereby obtained, which was dissolved in ammonia and precipitated from this solution by acetic acid; this solution and precipitation was repeated several times, and a product was obtained, which, after washing with potassium iodide and then water, was found to contain $8^{\circ} 93$ per cent. of iodine.

Kurajeff carried out a series of experiments under varying conditions. The treatment with iodine was carried out at $40^{\circ}$, both in acid solutions and in the presence of magnesium carbonate; he used as source of iodine in some experiments, potassium iodide and iodate in the presence of acids, in others iodine dissolved in potassium iodide, with small quantities of iodate. When crystallised serumalbumin was treated with these varying mixtures at $40-50^{\circ}$ for from three to seven days, preparations were obtained containing from about IO-I2 per cent. of iodine. By means of varying mixtures at $100^{\circ}$ (one to six hours), preparations containing between II 48 and 1 2.28 per cent. of iodine were obtained.

Hofmeister's method appears to give more constant results. With egg-albumin (crystallised) at the lower temperature, with iodine, potassium iodide and potassium iodate, preparations containing from $8 \cdot 29-8 \cdot 42$ per cent. iodine were obtained. When, however, potassium iodide, with iodic and sulphuric acids, was used (five days at $40^{\circ} \mathrm{C}$.), a preparation containing only 5.94 per cent. of iodine was obtained. It may be recalled that Hofmeister's preparation, obtained by treatment with potassium iodide and iodic and sulphuric acid for four hours at $90-100^{\circ}$, contained 8.93 per cent. iodine.

Blum and Vaubel claim to be able to obtain products with constant iodine content by their method already referred to; they propose to designate this the Blum-Vaubel iodine number, and to make the preparation under the following conditions: The protein is either dissolved or suspended in water, to which sodium bicarbonate is added, and the mixture is then warmed to $40-50^{\circ} \mathrm{C}$. Iodine dissolved in potassium iodide solution is then added in small quantities at a time, till the iodine colour becomes permanent (i.e., does not disappear after half an hour). The mixture is then cooled and filtered, sodium hydroxide is added in excess, and immediately afterwards acetic acid. If necessary alcohol or acetone is added to complete the precipitation. The precipitate is purified by resolution in alkali and reprecipitation by acid, and then washed by water and alcohol until the washings are free from iodine. The percentage of iodine contained in the dried preparation is the "iodine number" of the protein. The iodine numbers found for various proteins by Blum and Vaubel are as follows: Serum-globulin, 8.45; serum-albumin (preparations by different methods), I I 02 and $90^{\circ} 93$; "-muscle-albumin," 10`37; egg-albumin, 7·1.

The above examples show sufficiently the variations in the iodine content of preparations prepared by different methods.

\section{Properties of the Halogen Derivatives of the Proteins and Nature of the Action of the Halogens.}

The properties of the halogen derivatives have been to a great extent indicated. They are readily soluble in alkaline solutions, 
from which they can be precipitated by means of acids. Some of them are, however, soluble in excess of acid. The higher bromine derivatives are soluble in alcohol, but insoluble in ether, chloroform, benzene and other organic solvents. They cannot be precipitated from their solution in alkali by the majority of the alkaloidal reagents, although they can be "salted out" by the addition of ammonium sulphate. None of them have been obtained in a crystalline form. They give the biuret reaction, but not the reactions of Millon or Adamkiewicz (Hopkins).

The possible reactions are very complicated, for the amount of hydrochloric, hydrobromic or hydriodic acid eliminated in the reaction is far larger than that which can be accounted for by the mere substitution of hydrogen by halogen. Concurrent oxidation must also take place.

Some light has recently been thrown on the action of chlorine on amino bodies by the researches of Raschig and of Cross, Bevan and Briggs.

Raschig has shown that chlorine and alkaline hypochlorites act upon ammonia with the formation of chloramines:-

$$
\mathrm{NH}_{3}+\mathrm{M}^{\prime} \mathrm{OCl}=\mathrm{NH}_{2} \mathrm{Cl}+\mathrm{M}^{\prime} \mathrm{OH} \text {. }
$$

Chloramine is capable of reacting with iodides with the liberation of free iodine :-

$$
\mathrm{NH}_{2} \mathrm{Cl}+2 \mathrm{HI}=\mathrm{NH}_{3}+\mathrm{HCl}+\mathrm{I}_{2} \text {. }
$$

Proteins seem to undergo a similar reaction, and it is suggested by Cross, Bevan and Briggs that such a reaction may serve as a measure of the reactive amino groups in the protein molecule. It is possible that the treatment with hypochlorites in alkaline solution will bring about a simple substitution, and that by means of the iodide reaction the chloramine groups in the protein molecule can be estimated. Evidence has already been brought to show that the hypochlorite does not react to such an extent as free chlorine. It is, furthermore, only the chlorine in the chloramine radical which sets free iodine from combination with iodides. ${ }^{1}$

The action of halogens is, however, far more complex than mere substitution in the sense of the chloramine reaction. Substitution may take place in groups other than the amino groups. Attention has been already called, furthermore, to the fact that far more of the hydrogen halide is set free in the reaction than can be accounted for by mere substitution. Oxidation must take place concurrently with substitution. Some idea as to the reaction may be obtained by the comparison of the empirical constitution of the halogen derivative with that of the original body. Hofmeister, Kurajeff and the other investigators give several analyses which throw light on this point. One example will suffice, viz., the analysis of crystallised

\begin{tabular}{|c|c|c|c|c|c|}
\hline Albumin & $\begin{array}{c}\text { C. } \\
53^{\prime} 28\end{array}$ & $\begin{array}{c}H . \\
7^{\circ} \cdot 26\end{array}$ & $\begin{array}{l}\mathrm{N} . \\
15^{\circ} \mathrm{O}\end{array}$ & I. & $\begin{array}{r}\text { S. } \\
\mathbf{r} \cdot \mathbf{1} 8\end{array}$ \\
\hline Ioda & $47 \cdot 92$ & $6 \cdot 60$ & $14^{\circ} \mathrm{I} 7$ & 8.95 & $I \cdot 26$ \\
\hline
\end{tabular}
egg-albumin, and its iodo derivative as prepared by Hofmeister :-

From these numbers it will be evident that in the formation of the

"Further research on this "chloramine factor" is necessary. A method is suggested in the paper of Cross, Bevan and Briggs, which is, however, only of a preliminary character. 
iodo derivative some carbon complex which is poor in nitrogen has been eliminated from the molecule; this Hofmeister assumes to be a carbohydrate group.

Again, Blum and Vaubel, by their method of forming these halogen derivatives in the presence of alkalis, bring some evidence to show that a separation of some sulphur body takes place, although this probably does not happen when other methods are employed.

Another significant fact with regard to the properties of the halogen derivatives is their failure to give a positive result when tested by the Millon and Adamkiewicz (Hopkins) reaction. This fact indicates either that the aromatic groups are so substituted by halogen that they fail to give these reactions, or that they are entirely destroyed.

Investigations on the groups that have been eliminated during halogenisation have been undertaken by Schmidt, who has isolated the simpler bye-products of the reaction. He has shown that ammonium iodide and ammonium iodate are always formed when the iodine derivatives are prepared from egg-albumin by the Hofmeister reaction. This indicates the scission of some amido group. Investigations with simpler bodies, such as ammonium salts, urea, arginine, aspartic acid and guanidine, showed that iodine is capable of causing the scission of $\mathrm{NH}_{2}$ groups from those bodies where the group is combined through a carboxyl or imido group to the molecule, such as in urea and in guanidine. In other bodies, such as aspartic acid, where the $\mathrm{NH}_{2}$ group is directly united to a carbon atom, no iodate could be detected as a bye-product of the reaction. The reaction with ammonium salts may be represented by the following equation:-

$$
6\left(\mathrm{NH}_{4}\right)_{2} \mathrm{SO}_{4}+6 \mathrm{I}+{ }_{3} \mathrm{H}_{2} \mathrm{O}={ }_{5} \mathrm{NH}_{4} \mathrm{I}+\mathrm{NH}_{4} \mathrm{IO}_{3}+6 \mathrm{NH}_{4} \mathrm{HSO}_{4} \text {. }
$$

It appears, therefore, from the somewhat limited number of Schmidt's experiments, that the estimation of the free ammonium salts eliminated may form a measure of the number of amido groups in the protein molecule. The reaction is, however, somewhat complicated, and the scission of amido groups cannot be directly measured by the iodate eliminated, for, owing to concurrent oxidation, relatively large quantities of hydriodic acid are formed simultaneously, and this, when it reaches a certain concentration, reduces the iodate according to the following equations:-

$$
\begin{aligned}
& \mathrm{HI}+\mathrm{NH}_{4} \mathrm{IO}_{3}=\mathrm{NH}_{4} \mathrm{I}+\mathrm{HIO}_{3} . \\
& \mathrm{HIO}_{3}+5 \mathrm{HI}=6 \mathrm{I}+3 \mathrm{H}_{2} \mathrm{O} .
\end{aligned}
$$

The amount of iodate formed can, therefore, only reach a certain limit.

Other bye-products isolated by Schmidt are iodoform, carbonic, formic and acetic acids, and possibly also para-iodopyrocatechin. These have been estimated quantitatively, and their formation is ascribed to the destruction of the tyrosine complex. Certain conclusions of Schmidt's later papers are not in full concordance with those arrived at earlier, especially with reference to the formation of iodates only by certain amino groups.

Sufficient has been said to show how complex are the possible reactions which can take place when proteins are treated with halogens. Nevertheless, it is conceivable that certain standard conditions for halogenisation can be fixed, by means of which halogen- 
protein derivatives can be prepared with fixed halogen content, which could serve for the characterisation of individual proteins. The bromination method of Hopkins and Pinkus, and the iodination method of Blum and Vaubel, might, under certain stringent specified conditions, be employed, and in this way a factor obtained for the characterisation analogous somewhat to the "Hübl number" for fats. The suggestion of Cross, Bevan and Briggs for a "chloramine" number is also worthy of further attention.

\section{Section XX.-The Action of Nitrous Acid on Proteins.}

When proteins are treated with nitrous acid a considerable frothing and evolution of nitrogen takes place. This action has formed the subject of many investigations. Schiff, on treatment of eggproteins with nitrous acid, obtained a product which no longer gave the biuret reaction, which was insoluble in water, and to which he gave the name desamido-albumin, on the assumption that nitrous acid had destroyed the amido groups (i.e., groups containing the complex - $\mathrm{CO} . \mathrm{NH}_{2}$ ). The action of nitrous acid on proteoses and peptones formed the subject of investigations by Paal and Schrötter, who obtained products differing in many properties from the original substances. In more recent times the action of nitrous acid has formed the subject of investigations by Levites, and more especially by Skraup and his pupils. Both these investigators failed to confirm the observation of Schiff, that the product of the reaction yields no biuret reaction. Levites found, moreover, that the products contained as much amide-nitrogen as the original bodies. Skraup and his pupils have prepared these desamido-proteins from several proteins (caseinogen, gelatin, serum-globulin), and subjected them to hydrolysis. They found that, with one exception, the hydrolysis products did not differ very essentially from the original proteins. They failed, however, to isolate lysine from the desamido-proteins, although this base was obtainable from the proteins themselves. The elementary compositions also did not differ very greatly from those of the proteins; the ratios of the carbon, hydrogen and nitrogen were approximately the same; in the case of caseinogen the desamido body contained considerably less phosphorus than the protein from which it was derived. The yield of desamido body varied considerably with the different proteins, although approximately the same methods of preparation were employed (mixture of sodium nitrite and protein solution treated with acetic acid); from gelatin the yield was about 100 per cent. of that of the protein, from caseinogen 70 per cent., and from crystallised egg-albumin about 50 per cent. Obermayer, and more recently Treves and Salomone, have stated that diazo compounds can be obtained from proteins by the action of nitrous acid, and from these dye-stuffs can be prepared.

\section{The Amino-Index.}

As to the mechanism of the action of nitrous acid little is yet known. E. Fischer and Koelker have shown that nitrous acid, when acting on polypeptides, causes an evolution of nitrogen, the quantity of which bears no very definite atomic ratio to the nitrogen of the polypeptide. It is possible from the colour of the products that 
nitroso bodies are formed, which on hydrolysis might be expected to yield the same products as the substances from which they are formed, with evolution of ammonia (Paal).

On the other hand, the free amino groups in the molecule, as well as the amide-nitrogen groups, might be attacked, as in the case of asparagine-

$$
{ }_{2} \mathrm{C}_{4} \mathrm{H}_{8} \mathrm{~N}_{2} \mathrm{O}_{3}+2 \mathrm{HNO}_{2}={ }_{2} \mathrm{C}_{4} \mathrm{H}_{6} \mathrm{O}_{5}+2 \mathrm{~N}_{2}+{ }_{4} \mathrm{H}_{2} \mathrm{O} \text {. }
$$

The amount of nitrogen evolved might serve as a measure of the free amino and amide groups in a protein. It must be remembered, however, that the polypeptides also act on nitrous acid in a somewhat indefinite manner (Fischer and Koelker); furthermore, in highly complex substances, such as the proteins, it is also conceivable that only a limited number of amino or amide groups may be the subject of attack, owing to stereo-chemical reasons. Nevertheless, the amount of nitrogen eliminated by nitrous acid treatment under certain specified conditions may be a fixed quantity and a characteristic of each individual protein, and the determination of this so-called aminoindex has formed the subject of recent investigation by Horace Brown and his co-workers. It has so far only been applied to a limited number of proteins. When a pure amino-acid, such as aspartic acid, is treated with nitrous acid, twice as much nitrogen is evolved as the acid itself contains, one-half being derived from the nitrous acid, e.g. :-

$$
\mathrm{C}_{4} \mathrm{H}_{7} \mathrm{O}_{4} \mathrm{~N}+\mathrm{HNO}_{2}=\mathrm{C}_{4} \mathrm{H}_{6} \mathrm{O}_{5}+\mathrm{N}_{2}+\mathrm{H}_{2} \mathrm{O} .{ }^{1}
$$

In the case of proteins, therefore, one-half the nitrogen evolved, expressed as a percentage of the total nitrogen, gives the apparent proportion of the nitrogen present in the amino form, or, at any rate, that proportion which will react with nitrous acid. This is termed by Brown the amino-index, and is represented by the symbol AoI. The following are the amino numbers for a series of proteoses and peptones obtained by fractionating malt proteoses:-

$\begin{array}{crr}\text { Malt proteoses I. } & 4{ }^{\circ} \\ \text { ", } & \text { II. } & 5^{\circ} \circ \\ \text { Malt peptone } & \text { II. } & 20^{\circ} \circ \\ \text { II. } & \text { II. } & 10^{\circ} 9 \\ & & \end{array}$

\section{Method.}

The method of determining the amino-index adopted by Brown and his co-workers is a modification of that previously employed by Sachsse and Kormann for determining the amino-acids present in certain technical samples. The principle consists in the treatment of the substance under examination with nitrous acid in statu nascendi, and the measurement of the nitrogen evolved after absorption of the surplus nitric oxide carried over by the gas. Certain errors were found by Brown to be inherent in the method as originally suggested by Sachsse and Kormann. The chief sources are due to (I) the residual air in the apparatus, or dissolved in the liquid; (2) difficulties attending the production of carbonic acid of high degree of purity when this is employed for freeing the apparatus from air; (3) difficulties associated with the complete absorption of nitric oxide with

${ }^{1}$ With asparagine containing an amido group only relatively half as much nitrogen is evolved, See equation already given above. 
ferrous sulphate. In order to get the apparatus air-free the tube in which the nitrous acid is allowed to act on the protein is connected with the carbonic acid generating apparatus by means of a special form of trap, from which the air is expelled by means of steam and carbonic acid gas. The latter is evolved by the action of hydrochloric acid on sodium carbonate solution in an apparatus specially designed for the mixture of the liquids, in such a way as to ensure a steady evolution of gas. The evolved nitrogen is collected over potash solution in a modified form of Lunge nitrometer, in which it is mixed with excess of oxygen, obtained by the electrolysis of water ; in this way the nitrogen is freed from the nitric oxide. The excess of oxygen is afterwards absorbed in alkaline pyrogallol solution, and the volume of nitrogen evolved is finally measured over pure water. Precautions must be taken to free all the liquids used in the experiments from air. For full details reference must be made to the original paper.

\section{Section XXI.-Action of Formaldehyde on Proteins.}

From the presence of amino and imino groups in proteins it is to be expected that they would enter into reaction with formaldehyde. The first observations on such a reaction are due to Trillat and Hauser. The former noticed that on addition of concentrated formaldehyde solution, egg-white was converted into an opaque gelatinous mass, whilst the latter noticed that gelatin, on treatment with formaldehyde, was converted into a hard, insoluble substance. Blum, somewhat later, noticed that the addition of a small quantity of formaldehyde to egg-white solution caused the latter to lose its capacity for coagulating on heating; it remained, however, clear after the addition of the aldehyde. The observations of Blum and of Trillat do not appear to be concordant; but the apparent discrepancy was later explained by Schwarz, who showed that dilute solutions, especially in absence of salts, remain clear on addition of formalin, and lose their coagulability, whereas more concentrated solutions become turbid, but can be made to coagulate by the addition of salts. These phenomena indicate that formaldehyde is capable of acting on proteins.

The reaction was studied in greater detail by Benedicenti. $\mathrm{He}$ added dilute ( 2 per cent.) solutions of formaldehyde to protein solutions, and estimated quantitatively at given intervals the amount of formaldehyde which had not entered into reaction; for this purpose he employed hydroxylamine hydrochloride, which reacts with the aldehyde according to the equation

$$
\mathrm{NH}_{2} \cdot \mathrm{OH} \cdot \mathrm{HCl}+\mathrm{H} \cdot \mathrm{CHO}=\mathrm{CH}_{2}: \mathrm{N} \cdot \mathrm{OH}+\mathrm{HCl} \text {. }
$$

By titrating the hydrochloric acid with standard potassium hydroxide, using methyl orange as indicator, the amount of formaldehyde in a solution could be estimated. It was noticed that when methyl orange was employed as indicator the proteins themselves acted as bases; a certain amount of acid was therefore necessary to neutralise the solution to this indicator before the addition of the hydroxylamine. This alkalinity diminished as the action of formaldehyde proceeded; this fact indicated that the alkalinity was due to the presence of amino groups, and gradually diminished, as the formaldehyde condensed with them to form methylene derivatives. 
The reaction with dilute formaldehyde solutions (e.g., 4 c.c. of a 2 per cent. solution added to ro c.c. of a protein solution) was somewhat slow; the maximum amount of aldehyde had not, as a rule, entered into reaction until after two to three weeks; after this interval it was found that I gram of gelatin (a ro per cent. solution of which had been boiled to prevent subsequent setting to a jelly) combined with 0.0135 gram formalin; Io c.c. fresh egg-white combined with 0.375 gram, 2 grams powdered egg-white with 0.0360 gram, I0 c.c. blood-serum with 0.315 gram, 3 grams fibrin with 0.0345 gram, and 5 grams caseinogen with 0.0294 gram formaldehyde. The compounds thus formed were no longer digestible when treated with pepsin, but could be decomposed when distilled with steam, and a digestible protein could be thereby recovered; the formaldehyde could also be quantitatively recovered in the distillate. Similar results to those of Benedicenti have been obtained recently by Treves and Salomone.

Schiff has also investigated the action of formaldehyde on proteins. He added a concentrated solution of formaldehyde (40 per cent.) to a solution of proteins, and then estimated the acidity of the latter. The reaction which takes place is assumed to be similar to that which takes place with the amino-acids. The amino group entering into reaction with the aldehyde forms methylene derivatives; the alkalinity due to the presence of such groups is thereby eliminated, and the acid, which before treatment acts practically as a neutral body to most indicators, now becomes strongly acidic in character, and can be titrated directly with alkalis, with the use of phenol-phthalein. By using this method Schiff found that I gram molecular equivalent of potassium hydroxide neutralised 3,231 grams of egg-albumin and 4,680 grams of gelatin, after solutions of the latter had been treated with formaldehyde. The titrations were carried out in some cases directly after mixture of the proteins with the aldehyde, and in other cases after the mixtures had stood for twenty-four or forty-eight hours. The same amount of alkali was required for neutralisation in each case. The result is not quite in accord with those of Benedicenti, who found the reaction was only complete after two or three weeks; he used, however, only very weak aldehyde solutions, whereas Schiff used the undiluted commercial preparation (40 per cent.).

The results seem to indicate that the reaction may be of use in estimating the amino and carboxyl groups in individual proteins, and thereby obtaining other factors for their characterisation. It has been already employed by Sörensen in studying the process of digestion of proteins by enzymes. As hydrolysis proceeds and the polypeptide groups are broken down, the number of free amino and carboxyl groups in a given amount of the solution increases; by treating the products of digestion with formaldehyde at different intervals, and then titrating the mixture with barium or sodium hydroxide, using phenol-or thymol-phthalein as indicator, Sörensen has succeeded in obtaining a new factor for the study of proteolysis by enzymes.

It seems possible that the amino and carboxyl factors in any protein may be determinable by a similar method, if the suitable experimental conditions be ascertained. Such factors might be of value for their characterisation. 
PART III.

\section{BIOLOGICAL METHODS FOR THE IDENTIFICATION AND DIFFERENTIATION OF PROTEINS. ${ }^{1}$}

\section{Section XXII.-The Precipitin Reaction.}

WHEN the necessity arises for differentiating between nearly allied proteins of different origins the ordinary chemical and physical methods entirely fail. No reliable chemical methods exist for distinguishing, for example, between human blood and the blood of other species, or between the muscular tissue of one animal and the muscular tissue of another. Yet, in actual practice, both in forensic medicine and in the ordinary routine of food-inspection and analysis, the necessity for determining differences of this description frequently arises. For this purpose biological methods, and especially the socalled precipitin reaction, have hitherto been almost exclusively employed.

The first observations dealing with this subject date from 1897 and are due to Kraus, who showed that by the injection of typhus bacilli into an animal a serum was produced, which not only caused agglutination of the bacteria, but also produced a precipitate with the filtrate of the culture medium. The reaction was found to be specific for certain substances contained in this medium.

In 1899 Bordet and Tschtistowitsch obtained quite similar results with animal cells and cell products. By the injection of horseserum, eel-serum, cows' milk, etc., into rabbits, sera could be obtained, containing the so-called precipitin, which gave thick precipitates with the substances used to produce them, and with these substances (the so-called precipitinogens) only. A relatively simple biological method was, therefore, available for distinction between proteins from various sources.

A large number of investigations followed the observations of Bordet, which were undertaken with the main object of determining how far the reactions were distinctly specific.

Bordet himself showed that the serum of a rabbit, immunised against cows' milk, produced a precipitate with this milk and not with that of a goat, and Wassermann and Schütze, Uhlenhuth and others found a similar specificity for precipitins produced by egg-white and blood. Of special interest are the blood precipitins. If human blood be injected into a rabbit a serum is produced which gives a

1 There is a very large literature on this subject, which can be only very briefly dealt with in this place. Excellent summaries are given together with the principal literature references in the papers of L. Blum and G. Blume. Reference should also be made to the exhaustive monograph on the blood test by Nuttall. 
strong precipitate with human blood, but not with that of a goat or a dog. Such a serum will, however, precipitate the blood of a species nearly allied to that from which the precipitinogen is obtained, and the precipitin produced by the injection of human blood will precipitate that of an anthropoid ape, although the amount of precipitate formed will differ quantitatively in different cases. The specificity of the precipitin reaction is, therefore, not absolute.

In order to produce precipitins the substance injected must be foreign to the animal employed. With a protein derived from the same species precipitins (the so-called “iso-precipitins") are obtained only in exceptional cases. To produce the most favourable results the animals employed for producing the precipitins should not be too closely allied to the animal from which the precipitinogen has been obtained, although Uhlenhuth has recently succeeded in obtaining a precipitin for hares' blood, but not for that of a rabbit, by introducing into the latter the blood of the former animal.

In addition to the experiments with native proteins, experiments for production of precipitins from chemically changed proteins have also been carried out. Precipitins have been produced from crystallised egg- and serum-albumins, although, according to Obermayer and Pick, the precipitin-producing property of these substances is lost after repeated recrystallisation. The precipitinogenic property is not lost, however, by heating, and precipitins can be produced by the injection of coagulated proteins. The property does not appear to be lost even by boiling with $\frac{1}{2}$ per cent. hydrochloric acid or sodium hydroxide solutions; neither does it appear as if the property is readily lost by the tryptic digestion of the precipitinogens, although it is readily lost by the peptic digestion. For this reason it is not, as a rule, possible to produce precipitins by the administration of precipitinogens per os, although the formation may, in certain cases, take place when a particular protein is ingested in such large quantities that it escapes the action of the peptic juice.

Proteins, therefore, which have undergone considerable changes, either by oxidation or hydrolysis, still possess the property of producing precipitins, which are specific for the species of animal from which they have been obtained. There is, however, according to Obermayer and Pick, another class of changed proteins in which this kind of specificity has been lost. Iodo-, nitro- and diazo-proteins, for example, will also yield precipitins, but these are specific, not for a particular animal species, but for other substances of the same class; thus a precipitin which has been produced by the injection of an iodo-protein from ox-serum is not specific for ox-serum, or even the iodo derivatives from ox-serum, but will precipitate iodoproteins from other sera, and even an iodo-protein derived from a plant. Furthermore, although an animal cannot, as a rule, produce a precipitin for one of its own proteins, it can produce one for a changed protein. In this way a xantho-protein precipitin has been produced by the injection of xantho-protein derived from rabbits' serum into a rabbit. Obermayer and Pick think that the animal species specificity is due to the aromatic groups, and that this particular kind of specificity is lost by the treatment of the protein by reagents, such as halogens, nitric acid, etc., which have a tendency to destroy these groups. 
The precipitate formation takes place most readily in neutral solution, and is impeded by the presence of mineral acids or alkalis ; the presence of salts is necessary, those of calcium exerting a specially favourable influence.

On heating a serum containing a precipitin, its capacity for forming precipitates is lost; the changed precipitin (precipitoid) retains, in spite of this fact, its capacity for combining with a substance contained in the precipitinogen.

As to the actual chemical nature of the precipitin, precipitinogen and precipitate but little is known; the substance of the last-named appears to be derived chiefly from the precipitin containing serum (Welsh and Chapman), although opinions on this point are not unanimous. The precipitates, furthermore, are soluble in excess of the precipitable substances.

The conditions of chemical equilibrium have been recently investigated by Hamburger and Arrhenius. The precipitin used in their experiments was contained in the serum of a calf which had been immunised against horse's serum. In one set of experiments a constant quantity of the calf-serum was added to varying quantities of diluted horse-serum ( $\mathrm{I}$ in 50 ); the mixture was allowed to remain at $37^{\circ} \mathrm{C}$. for one hour, and then centrifuged in a funnel-shaped tube ending in a graduated capillary tube, in which the precipitate formed could be collected and measured. In a second series of experiments the quantity of horse-serum was kept constant and that of the calf-serum varied. If the solubility of the precipitate in physiological saline (the diluent used) were the only factor which caused the diminution of the quantity of the precipitate, then, according to the Guldberg-Waage hypothesis-

\section{Concentration of precipitinogen $\times$ concentration of precipitin $=$} $\mathrm{K}$ (reaction constant) $\times$ concentration of dissolved precipitate.

The quantity of dissolved precipitate was, however, larger than could be accounted for by the above equation, and Hamburger and Arrhenius came to the conclusion that a soluble substance is formed by the combination of the precipitate with some substance in the precipitinogenous body (i.e., horse-serum), and that the conditions are analogous to those existing in the $\mathrm{Ca}(\mathrm{OH})_{2}: \mathrm{CO}_{2}$ reaction.

A detailed account of the precipitin reaction and of the theories that have been advanced to explain the precipitin formation need not be discussed here; it remains, however, to consider briefly the practical applications of the reaction and the technique of the methods employed.

The method for determination of the species origin of a protein is due chiefly to Wassermann and Uhlenhuth. ${ }^{1}$ It has been studied in great detail by Nuttall, and has been recently modified by A. Schulz and extended by him to the quantitative estimation of mixtures of proteins. Owing to the fact already mentioned that the precipitin reaction is not strictly specific for a protein of any given species, great care is required in the application of the reaction.

${ }^{1}$ A recent detailed account of the method for technical purposes has been published by Uhlenhuth and his co-workers (Arbeiten aus dem Kaiserlichen Gesundheitsamt, 1908, vol. xxviii., pt. 3). 
The precipitin is generally prepared by several injections, generally intraperitoneal, but sometimes subcutaneous or intravenous, following one another at intervals of from three to six days. ${ }^{1}$ Rabbits are the animals commonly employed. The more precipitin a serum contains the less specific is it, i.e., the more readily will it precipitate proteins other than the precipitinogen. For practical purposes, therefore, it is not advisable to employ precipitins of very high grade; if sera be obtained which give precipitates with bodies other than the precipitinogens, it is advisable to dilute them before use. In determining the origin of a sample of blood the material to be investigated (clothes, etc.) is extracted with physiological saline, and the extract is filtered through a Berkefeld filter and diluted, so that a solution containing $0^{\circ} \mathrm{I}$ per cent. protein is obtained. To 2 c.c. of such a solution $O^{\circ}$ I c.c. of the precipitin-containing serum is added. The more nearly the protein in the material under investigation is allied to the precipitinogen employed for the preparation of the antiserum, the greater the dilution in which a precipitate will appear. To determine, therefore, the origin of a given sample of blood (e.g., human blood), samples of other bloods should be used as controls; the precipitin prepared by immunising a rabbit against human blood, for example, will give with the material under investigation a precipitate in much greater dilution, should it contain human blood, than it would if it contain blood from any other species. Furthermore, the more nearly allied the species to that 'from which the precipitinogen has been derived, the more readily will its protein give a precipitate with the precipitin. This reaction has been extensively employed by Nuttall for determining the genetic relationships of different species.

Another method of applying the precipitin reaction has been recently introduced by Neisser and Sachs. When hæmolysis of red blood corpuscles is brought about by a serum the latter contains two different bodies, both of which are necessary for the process, viz., the heat-labile complement and the heat-stable amboceptor. Gengou has shown that, when a precipitate is formed by bringing together precipitin and precipitinogen in the presence of a hæmolytic serum, the complement disappears, even when the amount of precipitate is so small as to be hardly visible. A hæmolytic serum can be tested as regards its hæmolytic power towards a given suspension of red blood corpuscles. To a similar quantity of the same serum may be added a precipitin-containing serum which is not hæmolytic towards the same corpuscles. If to such a mixture a protein be added containing a substance which will form a precipitate with the precipitin, it will lose its hæmolytic properties. In this way Neisser and Sachs have succeeded in detecting human blood in dilutions of $I$ in 10,000 , or even I in 100,000. For suggested explanations of these phenomena reference must be made to the original papers.

To illustrate the method of employment of the precipitin reaction a short description of Schulz's method for the quantitative estimation of proteins in mixtures is appended.

${ }^{2}$ Nuttall generally used 5-10 c.c. of serum for each injection, but in some cases smaller quantities. For details see his Monograph, pp. 54, 55. 


\section{Method.}

Schul's Method of Protein Estimation by Means of the Precipitin Reaction.-The experimental basis of the method depends upon the fact that if an antiserum be added to varying dilutions of an extract of its precipitinogen in physiological saline solution the turbidity due to the precipitate formation will appear earliest in the most concentrated solutions; the more dilute a solution the longer will be the time interval before turbidity appears. The strength (value) of an antiserum can be determined, therefore, by ascertaining the greatest dilution of the precipitinogen, which is just sufficient to give a turbidity within a given time interval, which for the purposes of experimental work has been chosen as sixty minutes. If the precipitinogenic protein be mixed with other proteins a more concentrated extract will have to be employed to yield a turbidity within sixty minutes, than would be the case if the pure precipitinogenic protein, unmixed with others, had been employed. By determining the ratio of this dilution to the dilution of the extract of the pure precipitinogenic body necessary to produce a turbidity within one hour, the amount of this substance in a given mixture can be ascertained. The principle of the method can be best illustrated by the example given by Schulz. A given amount of a mixture of horse flesh and other muscular tissue, weighing $50^{\circ} 57$ grams, containing $x$ grams of the former, was extracted with roo c.c. of normal saline $(k)$. This extract gave a turbidity within one hour with a given quantity of a serum produced by immunising a rabbit against horse flesh, when it was diluted I60 times. An extract of pure horse flesh gave a turbidity under the same conditions and with the same quantity of the same serum, when the extract was of such dilution that 820 parts corresponded to I part of the meat. The value of the serum used, W, was, according to Schulz's method of expression, $\frac{\mathrm{I}}{820}$. From these data the amount of horse flesh present in the mixture can be calculated from the equation $\frac{x}{160 k}=\frac{1}{820}$, whence $x=19^{\circ} 5$. That is to say, $50^{\circ} 57$ grams of tissue contained $19^{\circ} 5$ grams of horse flesh. The amount actually added to the mixture was $19^{\circ}$ o grams.

For the purposes of experimental work a serum not too rich in precipitin should be employed. It should be prepared by intraperitoneal injection of the protein, the quantity of which is to be estimated in a given mixture. The antiserum should be sterilised by filtration through a clay filter and kept in hermetically sealed glass tubes of $0^{\circ} 6$ c.c. capacity. Its value should be freshly tested against a pure precipitinogen whenever a quantitative estimation is carried out. The extracts of the precipitinogen and sample under investigation should be carefully filtered and perfectly clear. Physiological saline is used for the extraction of the material, which should be finely disintegrated, and kieselguhr serves as a good filtering medium. As there is a loss of protein during filtration, the precipitinogen and the sample under investigation should be treated in as nearly as possible the same way and the extracts filtered through exactly similar filters the same number of times. Various dilutions of the extracts can be readily prepared in series. To $0^{\circ} 9$ c.c. of each 
dilution contained in test-tubes of $53 \times 7 \mathrm{~mm}$., $0^{\circ} \mathrm{I}$ c.c. of the precipitin containing serum, measured from a I c.c. pipette graduated in $\frac{I}{100}$ c.c., is added, the mixture is shaken and the series of test-tubes allowed to stand for one hour. The dilutions of the pure precipitinogen and of the sample under investigation, which produce turbidity within this time, are readily observed, and the quantity of protein to be estimated can be readily calculated by the method already described. The dilutions are arranged by Schulz according to certain definite scales. The method has its limitations, for whereas it can be successfully applied to the estimation of a given description of muscular tissue in mixtures, even when the latter are not quite fresh, it fails when applied to egg-proteins.

The Complement Removing Action of Neisser and Sachs.-The following method,was employed for distinguishing between human blood and blood originating from other species. O.I c.c. of antiserum (i.e., serum of an animal immunised against human blood) +0.05 c.c. complement (fresh guinea-pig serum) + varying quantities of normal sera of different origins, made up always to a volume of I c.c. with physiological saline, were mixed and allowed to stand for one hour at room temperature; to each of the test mixtures was added I c.c. of a 5 per cent. suspension of sheep's blood + 0.00I 5 c.c. of amboceptor-containing serum (serum of a rabbit immunised against ox blood, such a serum acting hæmolytically also towards sheep's blood) ; the mixture was then allowed to stand at $37^{\circ} \mathrm{C}$. for two hours. Quantities of 'OOI c.c. of human serum caused total inhibition of hæmolysis; in presence of similar quantities of serum from monkeys a moderate amount of hæmolysis took place; whilst much larger quantities ('or c.c.) of sera from the rat, pig, goat, rabbit, ox and horse were incapable of preventing complete hæmolysis.

A simplification of the above process is possible. Normal rabbit's blood hæmolyses sheep's blood, and this can be employed instead of a prepared immune serum. It was found in Neisser and Sachs' experiments that 0.25 c.c. of rabbit's serum could completely hæmolyse I c.c. of a 5 per cent. suspension of sheep's blood. 0.25 c.c. of this serum was, therefore, mixed with the liquid supposed to contain human blood and the corresponding antiserum and allowed to remain for one hour at $37^{\circ}$. I c.c. of the 5 per cent. sheep's-blood suspension was then added, and the mixture incubated again at $37^{\circ}$ for two hours. The absence of hæmolysis indicated the presence of human serum.

The principle of the method has been applied to the identification of many proteins other than those contained in blood and serum. An account of the researches with literature references is given in the résumé of Blume. 


\section{CONCLUDING REMARKS.}

In the foregoing pages the chief properties of the proteins have been passed in review with the object of determining those which might serve for the purposes of isolation and identification. As a result it must be admitted that the methods available at the present moment are extremely defective.

The separation of the proteins from one another depends almost entirely on their differences of solubility in alcohol, water, salt solutions, or dilute acids and alkalis. To the incompleteness of the separation by differential extraction or by salt precipitation attention has been already drawn. Furthermore, there are large classes of proteins, to which even these methods are inapplicable, viz., those which are quite insoluble in the solvents mentioned. For the separation of mixtures of proteins of these classes no methods are available.

The methods for the identification of proteins are again extremely defective. The unreliability of the physical constants has been repeatedly emphasised. There remain the biological methods, which in recent years have received considerable attention, and a few isolated chemical factors, such as the sulphur content and the distribution of nitrogen in the hydrolysis products. The biological methods are, however, in many cases uncertain, and whilst they are generally available for the physiologist or pathologist, they are entirely beyond the scope of the worker whose only resource is a laboratory devoted to pure chemistry; the biological reactions, furthermore, require a considerable interval of time for their accomplishment. For these reasons their general application must be limited, and they are, for the most part, quite unavailable for the purpose of the technical examination of products, such as falls, for example, within the range of work of the food analyst.

For these reasons reliance will have to be placed chiefly on the purely chemical methods for the identification of proteins. Much work remains to be done in the elaboration of such methods, and it is not too much to hope that, with the rapidly increasing knowledge of proteins, a reliable technique will be developed in the near future, such as exists already for the identification and differentiation of fats. It is a necessity for the physiologist, the pathologist and the technical chemist. 


\section{BIBLIOGRAPHY.}

\section{"SALTING OUT" OF PROTEINS.}

Bömer. Zinksulfat als Fällungsmittel für Albumosen. Zeit. f. anal. Chem., I895, 34,562 .

Burckhardt. Beiträge zur Chemie und Physiologie des Blutserums. Arch. exp. Path. Pharm., I882, I6, 322.

DÉNIs. Nouvelles études chimiques. Paris, 1856.

DÉnis. Mémoire sur le Sang. Paris, I859.

Halliburton. The Proteids of Serum. Journ. Physiol., I884, 5, I52.

Halliburton. On Muscle Plasma. Journ. Physiol., r887, 8, r33.

Halliburton. The Proteids of Milk. Journ. Physiol., I89o, II, 448.

Hammarsten. Ueber das Paraglobulin. Pfluger's Archiv, I878, I7, 4I3 and I8, 25.

Haslam. The Separation of Proteids, I. Journ. Physiol., I905, 32, 267.

Haslam. The Separation of Proteins, II. Journ. Physiol., I907, 36, I64.

Heynsius. Ueber das Verhalten der Eiweissstoffe zu Salzen von Alkalien und von alkalischen Erden. Pflüger's Archiv, I884, 34, 330.

Hofmeister. Zur Lehre von der Wirkung der Salze. Arch. exp. Path. Pharm., $\mathrm{I} 887,24,247$ and $\mathrm{I} 888,25, \mathrm{I}$.

KAUDER. Zur Kenntniss der Eiweisskörper des Blitserums. Arch. exp. Path. Pharm., I886, 20, 4II.

Kühne. Erfahrungen über Albumosen und Peptone. Zeit. f. Biologie, r892, 29, I.

Köhne and Chittenden. Ueber die Peptone. Zeit. f. Biologie, I886, 22, 423.

LEwith. Zur Lehre von der Wirkung der Salze. Arch.exp. Path. Pharm., I887, 24, r.

MEHu. Methode d'extraction des pigments d'origine animale; applications diverses du sulphate d'ammoniaque. Journ. de Pharm. Chim., I878, 28, I59.

Osborne and Harris. Precipitation Limits of Globulins. Journ. Amer. Chem. Soc., I903, 25, 837 .

Panum. Neue Beobachtungen über die eiweissartigen Körper. Virchow's Archiv, $1852,4,419$.

PIcK. Untersuchungen über die Proteinstoffe. Zeit. physiol. Chem., I897, 24, 246.

Pick. Zur Kenntniss der peptischen Spaltungsprodukte des Fibrins. Zeit. physiol. Chem., I899, 28, 219, and Beitr. chem. Path. Physiol., I902, 2, 48I.

Pinkus. The Precipitation of the Proteids with Anhydrous Sodium Sulphate. Journ. Physiol., Igor, 27, 57.

Schäfer. Notes on the Temperature of Heat Coagulation of Certain Proteid Substances of the Blood. Journ. Physiol., 1880, 3, 181.

Starke. Beiträge zur Kenntniss des Serum- und Eieralbumins. Maly's Jahresber., I88I, II, I7.

VIRchow. Ueber ein eigenthümliches Verhalten albuminöser Flüssigkeiten bei Zusatz von Salzen. Virchow's Archiv, I854, 6, 572.

Wenz. Ueber das Verhalten der Eiweissstoffe bei der Darmverdaunng. Zeit. f. Biologie, I886, 22, I.

WEYL. Beiträge zur Kenntniss thierischer und pflanzlicher Eiweisskörper. Zeit. physiol. Chem., I877, I, 72.

Zunz. Ueber den quantitativen Verlauf der peptischen Eiweissspaltung. Zeit. physiol. Chem., 1899, 28, 132. Beitr. chem. Physiol. Path., I902, 2, 435.

\section{DEGREE OF SOLUBILITY OF PROTEINS IN SALT SOLUTIONS.}

Hardy. Colloidal Solution. The Globulins. Journ. Physiol., I905-6, 33, 25 I.

Mellanby. Globulin. Journ. Physiol., r905-6, 33, 338.

Osborne AND HARRIS. Solubility of Globulin in Salt Solutions. Amer. Journ. Physiol., I905, I4, I5I.

PAulı. Die physikalischen Zustandsänderungen der Eiweisskörper. Pfluger's Archiv, I899, 78, 3 I5. 


\section{SOLUBILITY OF PROTEINS IN ORGANIC SOLVENTS.}

Mayer and Terroine. Sur les propriétés des précipités d'albumine par l'alcohol. Bull. Soc. de biol., 1907, 62, 317.

Osborne and Voorhees, Osborne and Chittenden, Osborne and Harris and OThERs. Alcohol Soluble Proteins from Corn, Maize, Rye, Barley, etc. Numerous papers. Amer. Chem. Journ., I891, I892, I893 (13, I4, I5), and other papers.

Ramsden. Some New Properties of Urea. Proc. Physiol. Soc., July, Igoz.

Ritthausen. Die Eiweisskörper der Getreidearten. Bonn, 1872.

\section{SEPARATION OF PROTEINS BY PRECIPITANTS OTHER THAN SALTS.}

LANDSteINer and Uhlirz. Ueber die Adsorption von Eiweisskörpern. Zentr. Bak. u. Par. I., I906, 40, 265.

Michaelis and Rona. Eine Methode zur Entfernung von Kolloiden aus ihren Lösungen, etc. Biochem. Zeitsch., 1906, 2, 219; 1907, 3, 109; 1907, 4, Ir; 1907, 5, 365; I907, 6, I.

\section{CRYSTALLISATION OF PROTEINS.}

Abderhalden. Resorption des Eisens, etc. Zeit. f. Biol., I900, 39, I43.

Fremy and Valenciennes. Recherches sur la composition des oeufs dans la série des animaux. Compt. rend., $1854,38,469,525$ and 570. Ann. de chim phys., 1857 [3], 50, 129.

GƯRBER. Krystallisation des Serumalbumins. Sitzungsber. physik. med. Gesellsch. Würzburg, I894, p. I43.

Hartig. Ueber das Klebermehl. Bot. Zeit., 1850, no. 5, 88ז.

Hofmeister. Ueber die Darstellung von krystallisirtem Eieralbumin. Zeit. physiol. Chem., I889, 14, I65.

Hopkins. On the Separation of Pure Albumin from Egg-White. Journ. Physiol., I900, 25, 306.

Hopkins and Pinkus. Remarks on the Crystallisation of Animal Proteins. Journ. Physiol., 1898, 23, 130.

INAGAKI. Zur Kenntniss der Eiweisskrystallisation. Verh. der phys. med. Gesellsch. Würzburg, 1906, 38, I7.

Leipziger. Edestin, etc. Pfluger's Archiv, 1899, 78, 402.

MaschKe. Krystallisierte Proteinverbindung. Journ. prakt. Chem., 1858, 74, 436.

Osborne. Crystalline Vegetable Proteins. Amer. Chem. Journ., 1892, 14, 208.

RADLKOFER. Ueber Krystalle proteinartiger Körper pflanzlichen und thierischen Ursprungs. Leipzig, 1859.

Ritthausen. Die Eiweisskörper der Getreidearten. Bonn, I872.

Schimper. Ueber die Krystalle eiweissartiger Substanzen. Zeit. f. Krystallographie, I880.

Schmiedeberg. Ueber die Darstellung der Paranusskrystalle. Zeit. physiol. Chem., 1877, I, 205.

WALTHER. Zur Kenntniss des Ichthulins und seiner Spaltungsprodukte. Zeit. physiol. Chem., I891, 15, 477.

ZINOFFSKY. Ueber die Grösse des Hämoglobinmolekäls. Zeit. physiol. Chem., 1885, 10, 16.

\section{THE TEMPERATURE OF COAGULATION OF PROTEIN SOLUTIONS.}

ARonsteIn. Ueber die Darstellung salzfreier Albuminlösungen vermittelst der Diffusion. Pfliger's Archiv, 1874, 8, 75 .

HaAs. Ueber das optische und chemische Verhalten einiger Eiweisssubstanzen, inbesondere der dialysirten Albumine. Pfliger's Archiv, 1876, 12, 378.

Halliburton. The Proteins of Muscle. Journ. Physiol., I887, 8, 133.

Heynsius. Ueber Serumalbumin und Eieralbumin und ihre Verbindungen. Pflüger's Archiv, 1876, 12, 549 .

KüHNE. "Protoplasma und Contractilität." Leipzig, I864.

WolfGang Ostwald. Influence of Electrolytes on Coagulation Temperature. Abs. Chem. Soc., Igo8, i., p. 375.

PAULI. Ueber die physikalische Zustandsänderungen der Eiweisskörper. Pflüger's Archiv, 1899, 78, 315, and Part VI., Beitr. chem. Physiol. Path., I907, 10, 53 (with Handovsky), and Beit. chem. Physiol. Path., I908, II, 415. 
Schmidt (ALEx.). Weitere Untersuchungen des Blutserums, des Eiereiweisses und der Milch durch Dialyse mittelst geleimten Papieves. Pfliger's Archiv, 1875, II, I.

Starke. Beiträge zur Kenntniss des Serum- und Eieralbumins. Maly's Jahresber., I88I, II, I7.

WINOGRADOFF. Ueber Darstellung und Eigenschaften salzfreier Eiweisslösungen. Pflüger's Archiv, I875, II, 605 .

References to Table:-

Frédericq. Zentralbl. f. Physiologie, I890, 3, 60I (with references to papers in the Bulletin de l'Academie Royale de Belgique).

Freund and Joachim. Zeit. physiol. Chem., 1902, 36, 407.

v. Fürth. Lirgebnisse der Physiologie, I902, I (I), IIo.

Halliburton. Journ. Physiol., 1887, 8, 133 .

Hammarsten. Zeit. physiol. Chem., I884, 8, 467.

Hewlett. Journ. Physiol., 1892, 13, 798.

Lacqueur and Sackur. Beitr. chem. Physiol. Path., 1902, 3, 193.

Magnus-Levy. Zeit. physiol. Chem., 1900, 30, 200.

Mörner. Zeit. physiol. Chem., 1893, 18, 6r.

Preyer. "Blutcrystalle," Jena, 187I.

Starke. Maly's Jahresber., I88I, II, I7.

Weyl. Zeit. physiol. Chem., I877, I, 72.

\section{OPTICAL ROTATION OF PROTEIN SOLUTIONS.}

References to Table:-

Gamgee and Croft Hill. Ber., 1903, 36, 913.

Gamgee and Jones. Beitr. chem. Physiol. Path., 1903, 4, ro.

Hopkins. Journ. Physiol., I900, 25, 306.

Mörner. Zeit. physiol. Chem., r893, 18, 6r.

Osborne and Harris. Journ. Amer. Chem. Soc., 1903, 25, 842.

Willcock. Journ. Physiol., I908, 37, 27.

\section{MOLECULAR WEIGHT DETERMINATIONS BY CRYOSCOPIC METHODS.}

\section{A. Depression of Freezing Points.}

References to Table:-

Bugarsky and Liebermann. Pfluger's Archiv, 1898, 72, 70.

Ciamician and $Z$ anetti. Maly's Jahresber., I892, 3 .

Paal. Ber., 1892, 25, 1202; 1894, 27, 1827; and 1902, 35, 2195.

Sabanejew. Ber. Referatband, 1893,385 .

Sabanejew and Alexandrow. Ber. Referatband, 1891, $55^{8}$.

\section{B. Direct Determinations of Osmotic Pressure.}

Moore and Parker. Osmotic Pressure of Colloid Solutions. Amer. Journ. Physiol., $1902,7,261$.

Moore and Roaf. Osmotic Pressure of Colloidal Solutions. Biochem. Journ., 1907, 2,34 .

Reid. Osmotic Pressure of Proteids. Journ. Physiol., I904, 3I, 438.

REID. Osmotic Pressure of Hamoglobin Solutions. Journ. Physiol., 1905, 33, I2.

Starling. Function of the Glomeruli. Journ. Physiol., I896, 19, 312, and 1899, 24, 317.

\section{THE “GOLD NUMBER".}

Schulz AND Zsigmondy. Die Goldzahl und ihre Verwerthbarkeit zur Charakterisierung von Eireissstoffen. Beitr. chem. Physiol. Path., 1903, 3, 137.

Zsigmondy. Die hochrothe Goldlösung als Reagens auf Colloide. Zeit. anal. Chem., I90I, 40, 697 .

\section{FRACTIONAL FILTRATION OF PROTEINS.}

Bвснноц. Kolloidstudien mit der Filtrationsmethode. Zeit. physikal Chem., 1907, 60, 257.

BEснноLD. Ultrafiltration. Biochem. Zeitsch., 1907, 6, 379.

CRAw. On the Filtration of Crystalloids and Colloids through Gelatine; with Special Reference to the Behaviour of Hamolysins. Proc. Roy. Soc., 1906, 77B, $31 \mathrm{I}$.

Martin. Separation of Colloids and Crystalloids. Journ. Physiol., 1896, 20, 364 .

Osborne (W. A.). Caseinogen and its Salts. Journ. Physiol., I9oI-2, 27, 398. 
THE NITROGEN DISTRIBUTION IN THE PROTEINS.

GüMBEL. Ueber die Vertheilung des Stickstoffs im Eiweissmolekül. Beitr. chem. Physiol. Path., 1904, 5, 297.

HaUsmann. Ueber die Vertheilung des Stickstoffs im Eiweissmolekül. Zeit. physiol. Chem., 1899, 27, 95; 1900, 29, 136.

HENDERSON. Zur Kenntniss des durch Säuren abspaltbaren Stickstoffs der Eiweisskörper. Zeit. physiol. Chem., 1900, 29, 47.

KuTscher. Ueber die Verwendung der Phosphorwolframsäure bei quantitativen Bestimmungen der Spaltungsprodukte des Eizeisses. Zeit. physiol. Chem., 1900, 3I, 215 .

Osborne And Harris. Nitrogen in Protein Bodies. Journ. Amer. Chem. Soc., Ig03, 25,323 .

Schulze AND Winterstein. Ueber das Verhalten einiger Monaminosäuren gegen Phosphorwolframsäure. Zeit. physiol. Chem., I9or, 33, 574 .

Schulze AND Winterstein. Ueber die Trennung von Phenylalanin von anderen Aminosäurcn. Zeit. physiol. Chem., r9o2, 35, 40.

Skraup. Ueber den sogenannten Amidstickstoff der Proteine. Monatsh., 1908, 29, 255. See also Transactions of the Guinness Research Laboratory, Vol. I., Part 2.

THE SULPHUR, PHOSPHORUS AND HALOGEN CONTENT OF PROTEINS.

Baumann. Ueber das Normale Vorkommen von Iod im Thicrkörper. Zeit. physiol. Chem., 1895, 21, 3 I9.

Drechsel. Zur Chemie einiger Secthiere. Zeit. f. Biologie, 1896, 33, go.

DürING. Ueber Schwefelbestimmungen in verschiedenen animalischen Substanzen, etc. Zeit. physiol. Chem., r8g6, 22, 28r.

HARNACK. Ueber Iodospongin, die iodhaltige eiweissartige Substanz aus Badeschwamm. Zeit. physiol. Chem., 1898, 24, 412.

Hundeshagen. Ueber iodhaltige Spongien und Iodospongin. Zeit. angew. Chem., I895, 473 .

C. Тн. Mö̈NER. Zur Kenntniss der organischen Gerïstsubstanz des Anthozoenskeletts. Zeit. physiol. Chem., 1907, 51, 33; 1908, 55, 77.

Oswald. Die Eiweisskörper der Schilddrüse. Zeit. physiol. Chem., 1899, 27, I4.

Oswald. Zur Kenntniss des Thyreoglobulins. Zeit. physiol. Chem., I901, 32, I21.

Oswald. Weiteres über Thyreoglobulin. Beitr. chem. Physiol. Path., 1902, 2, 545; and other papers.

Plimmer and Bayliss. Separation of Phosphorus from Caseinogen by the Action of Enzymes and Alkali. Journ. Physiol., 1906, 33, 439.

Plimmer and Scotr. Trans. Chem. Soc., I908, 93, r699.

References to Table:-

(3) Bang. Zeit. physiol. Chem., I899, 27, 463.

(13) Chittenden and Osborne. Amer. Chem. Journ., r892, 14, 20.

(20) Chittenden and Solley. Journ. Physiol., I891, 12, 23.

(2) Fleroff. Zeit. physiol. Chem., I899, 28, 307.

(I) Goto. Zeit. physiol. Chem., 1902, 37, 84.

(8), (I7) Hammarsten. Pflüger's Archiv, I880, 22, 43r.

(I6) Hammarsten. Zeit. physiol. Chem., 1885, 9, 27.3.

(I9) Levene. Zeit. physiol. Chem., I901, 32, 28I.

(26) Lubarch. Encyclopædie der Mikroskopischen Technik. Berlin, 1903.

(5) Michel. Würzburger phys. med. Gesellsch. N.F., I895, 29, Ir7.

(9) Osborne. Amer. Chem. Journ., 1893, 14, no. 8.

(4), (12) Osborne and Campbell. Journ. Amer. Chem. Soc., 1899, $21,477$.

(7), (10), (14), (15) Osborne and Voorhees. Amer. Chem. Journ., I893, 15, 392.

(4) Schulz. Zeit. physiol. Chem., I898, 24, 449.

(24) Schwarz. Zeit. physiol. Chem., r893, 18, 487.

(25) Siegfried. Habilitationschrift. Leipzig, 1892.

(I8) Walter. Zeit. physiol. Chem., I89I, I5, 477 .

THE TYROSINE FACTOR FOR PROTEINS.

A. J. BRown AND E. T. Millar. The Liberation of Tyrosine during Tryptic Proteolysis. Trans. Chem. Soc., 1906, 89, 145.

H. J. Millar. A New Method for the Direct Estimation of Tyrosine in Mixtures of Amides and Amino-Acids. Trans. Guinness Laby., r9o3, I, 40.

REACH. Quantitative Untersuchungen über das Tyrosin als Spaltungsprodukt der Eiweissstoffe. Virchow's Archiv, path. Anat., 1899, 158, 288. 


\section{SALT FORMATION OF PROTEINS.}

BUGARSKY AND LIEBERMANN. Ueber das Bindungsvermögen eiweissartiger Körper für Salzsäure, Natriumhydroxid und Kochsalz. Pflüger's Archiv, r898, 72, 51 .

Connнeim. Ueber das Salzsäurebindungsvermögen der Albumosen und Peptone. Zeit. f. Biologie, r897, 33, 489 .

CoHnheIm AND KRIEger. Das Verhalten der Eiweisskörper zu Alkaloidreagentien zugleich eine Bestimmung der gebundenen Salzsäure. Zeit. f. Biologie, rgoo, 40, 95.

ERB. Das Salzsäurebindungsvermögen einiger reiner Eiweisskörper. Zeit. f. Biologie, rgor, 4I, 309.

Hardy. Colloidal Solutions. The Globulins. Journ. Physiol., r905, 33, 25 r.

LACQUEUR AND SACKUR. Ueber die säuren Eigenschaften und das Molekulargewicht des Caseins und seine Spaltung beim Trockenen. Beitr. chem. Physiol. Path., rgoz, 3, I93.

OsBorne. Der basische Charakter des Proteinmoleküls und das Verhalten des Edestins zu bestimmten Mengen von Säure und Alkali. Zeit. physiol. Chem., Igor, 33, 240.

VON RHORER. Ueber die Bestimmung der Säureverbindungsvermögen der Eiweissstoffe. Pfliger's Archiv, 1902, 90, 368 .

SرöQvist. Physiologisch.-chemische Betrachtungen über Salzsäure. Skand. Archiv, I895, 5, 277.

SPIRO AND PEMSEL. Ueber Basen und Säurecapacität des Blutes und der Eiweisskörper. Zeit. physiol. Chem., 1898, 26, 233.

\section{THE PRECIPITATION OF PROTEINS BY SALTS OF THE HEAVY ME'TALS.}

GaLEOTTI. Ueber die sogenannten Metallverbindungen der Eiweisskörper nach der Theorie der chemischen Gleichgewichte. Zeit. physiol. Chem., r904, 40, 492.

HARNACK. Untersuchungen über die Kupferverbindungen des Albumins. Zeit. physiol. Chem., r88r, 5, rg8.

PAULI. Untersuchungen über physikalische Zustandsänderungen der Kolloide IV. Eiweissfällung durch Schwermetalle. Beitr. chem. Physiol. Path., I905, 6, 233.

\section{OXIDATION OF PROTEINS.}

BЕ́сHАMP. Recherches sur les produits d'oxidation des substances albuminoids par le hypermanganate de potasse. Ann. de Chim., 1889, 57, $29 \mathrm{r}$.

Bernert. Ueber die Oxidation von Eiweiss mit Kaliumpermanganat. Zeit. physiol. Chem., 1898, 26, 272.

Blumenthal and Neuberg. Deutsch. med. Wochenschrift, rgor, no. 1.

BoNDZÝNSKI AND ZoJA. Ueber die oxidation der Eiweisstoffe mit Kaliumpermanganat. Zeit. physiol. Chem., 1894, I9, 225.

BRücke. Ueber eine durch Kaliumpermanganat erhaltene Säure. Sitzber. d. Wiener Akademie, r88 r, 83, III., 7 .

Chandelon. Beitrag zum Studium der Peptonisation. Ber., 1884, I7, 2143.

Ehrmann. Ueber die Peroxyprotsäure. Inaug. Diss. Strassburg, 1903.

von FürTH. Beiträge zur Kenntniss des oxydativen Abbaus der Eiweisskörper. Beitr. chem. Physiol. Path., r905, 6, 296.

Gorup-Besanez. Ueber die Einwirkung des Ozons auf organische Verbindungen. Annalen, I859, I10, 96.

Harries. Ueber Versuche zur Spaltung des Caseins vermittelst Ozon. Ber., I905, 38, 2990.

HaRRIES AND LANGHeld. Ueber das Verhalten des Caseins gegen Ozon. Zeit. physiol. Chem., rgo7, 5I, 342.

Kutscher AND Schenck. Die Oxydation von Eiweissstoffen mit Calciumpermanganat. Ber., r904, 37, 2928.

Löw. Ueber Eiweiss und Oxydation desselben. Journ. prakt. Chem., 1885, 3 I (2), I29.

MaLy. Ueber die Oxydation von Eiweiss mittelst Kaliumpermanganat. Sitzber. d. Wiener Akademie, I889, 97, II.

MALy. Ueber die bei der Oxydation von Leim mit Kaliumpermanganat entstehenden Körper und die Stellung von Leim zu Eiweiss. Sitzber. d. Wiener Akademie, I889, 98, II., Monatsh., I889, I0, 26.

Orgler. Ueber die Entstehung von Aceton aus krystallisirtem Ovalbumin. Beitr. chem. Physiol. Path., I90I, I, 583. 
Pотт. Oxydationsversuche mit Kaliumpermanganat. Journ. prakt. Chem., $1872,5(2)$, 355 .

Schulz. Ueber die Oxydation von krystallisiertem Eieralbumin mit Wasserstoffsuperoxyd. Zeit. physiol. Chem., I900, 29, 86.

Seeman. Ueber die Oxydation des Leims und des Eieralbumins mit Calciumpermanganat. Zentrbl. f. Physiologie, I904, I8, 285.

Siegried. Zur Kenntniss der Spaltungsprodukte der Eiweisskörper. Ber., I8gr, 24, 427.

Subbotin. Einiges über die Wirksamkeit des übermangansauren Kalis auf Albumin. Chem. Zentralb., 1865, 594 .

WURSTER. Ueber das Verhalten von Wasserstoffsuperoxyd gegen Eiweiss. Ber., 1887 , 20, 263 .

Zickgraf. Die Oxydation des Leims mit Permanganaten. Zeit. physiol. Chem., I904, $4 \mathrm{I}, 259$.

\section{THE ACTION OF HALOGENS ON PROTEINS.}

Blum. Ueber die Iodzahl der Eiweisskörper. Zeit. physiol. Chem., I899, 28, 288.

Blum and Vaubel. Ueber die Halogeneiweissderivate. Journal prakt. Chem., 1897, 56,$393 ; 1898,57,365$.

Bohm and Berg. Beiträge zur Pharmakologie der Iodes. Arch. exp. Path. Pharm., $1876,5,329$.

Cross, Bevan and Briggs. The Chloramine Reactions of the Proteins and Technical Applications. Journal Soc. Chem. Indust., I908, 27, 260.

Habermann and Ehrenfeld. Über Proteinstoffe. Einwirkung des nascirenden Chlors auf Casein. Zeit. physiol. Chem., I9or, 32, 467.

Hofmeister. Ueber iodirtes Eieralbumin. Zeit. physiol. Chem., 1897, 24, 159.

Hopkins and Pinkus. Zur Kenntniss der Wirkung von Halogenen auf Proteine. Ber., I898, 3I, гзг2.

JENDRASSIK. Quoted by Hofmeister.

KURAJEFF. Ueber Einfuihrung von Iod in das krystallisirte Serum- und Eieralbumin. Zeit. phys:ol. Chem., 1899, 26, 462 .

Lépinors. Action de l'iode sur les matières albuminoides. Journ. Pharm. Chim., $\mathrm{x} 897,[6] 5,56 \mathrm{x}$.

Liebrecht. Ueber Iodderivate von Eiweisskörpern (Casein). Ber., I897, 30, I824.

Lokw. Ueber Eiweiss und die Oxydation desselben. J. prakt. Chem., I885, 31, 129.

Mulder. Ueber Protein. Journ. prakt. Chem., x848, 44, 488.

PANZER. Ueber ein gechlortes Casein und dessen Spaltung durch rauchende Salzsäure. Zeit. physiol. Chem., Igor, 33, I3I.

Raschig. Monochloramin. Ber., I907, 40, 4586.

Rideal and Stewart. Note on the Determination of Proteids by Chlorine. Analyst, I $897,22,228$.

C. H. L. ScнмiDT. Ueber die Bedeutung der Iodsäurebildung bei der Iodirung des krystallisirten Eieralbumins. Zeit. physiol. Chem., I901, 34, 55.

C. H. L. Schмidт. Quantitative Bestimmung der bei der Iodirung von Albuminstoffen entstehenden Iodsäure und Iodwasserstoffsäure. Zeit. physiol. Chem., rgor, 34, I94.

C. H. L. Schmidt. Zur Kenntniss der Iodirungsprodukte der Albuminstoffe, I. Zeit. physiol. Chem., I902, 35, 386.

C. H. L. Schмidт. Zur Kenntniss der Iodirungsprodukte der Albuminstoffe, II. Zeit. physiol. Chem., I902, 36, 343 .

\section{ACTION OF NITROUS ACID ON PROTEINS.}

BRown. Description of an Improved Apparatus for the Sachsse-Kormann Process. Trans. Guinness Research Laboratory, I903, I, Part I., 30.

Brown. The Nitrogen Question in Brewing. J. Inst. Brewing, 1907, I3, 394 (p. 415).

Fischer AND KorLKer. Verhalten des Leucylisoserins und verwandter Körper gegen salpetrige Säure. Annalen, I905, 340, 177.

LAMPel. Ueber das Desamidoglobulin. Monatsh., 1907, 28, 625.

Levites. Ueber Desamidoalbumine. Zeit. physiol. Chem., I904, 43, 202.

Obermayer. (Abstract of patent specification.) Ber., 1894, 27, Abstracts, 354 .

PaAl. Ueber die Desamidirung des Glutinpeptons. Ber., I896, 29, 1085.

ScHifF. Ueber Desamidoalbumin. Ber., 1896, 29, 1354. 


\section{THE GENERAL CHARACTERS OF THE PROTEINS}

Schrötrter. Beiträge zur Kenntniss der Albumosen. Monatsh., I898, I9, 2 Ir.

Skraup. Ueber Desamidoglutin. Monatsh., I906, 27, 653; and 1907, 28, 447.

Skraup and Hokrnes. Ueber Desamidocasein. Monatsh., Igo6, 27, 631 .

SKRAUP AND KAAS. Ueber die Einwirkung von Salpetrigesäure auf Ovalbumin. Annalen, 1907, 351, 379.

Treves and Salomone. Ueber die Wirkung der salpetrigen Säure auf die Eiweisstoffe. Biochem. Zeitsch., I907, 7, Ir.

\section{ACTION OF FORMALDEHYDE ON PROTEINS.}

Benedicentr. Ueber die Einwirkung des Formaldehyds auf einigen Proteinstoffe. Archiv f. (Anat.) u. Physiol., 1897, 219.

Buum. Ueber eine neue Klasse von Verbindungen der Eiweisskörper. Zeit. physiol. Chem., 1896, 22, I27.

HAUSER. Ueber Verwendunge des Formalins zur Conservirung von Bakterienkulturen. Münch. med. Wochensch., rgo3, pp. 567-655.

ScHifF. Trennung von Amin- und Säurefunction in Lösungen von Eiweisskörpern. Annalen, I90r, 3r9, 287.

Schwarz. Ueber Verbindungen der Eizveisskörper mit Aldehyden. Zeit. physiol. Chem., Igor, 3r, 460.

Sörensen. Enzymstudien. Biochem. Zeitsch., I907, 7, 45.

Treves and Salomone. Ueber die Wirkung der salpetrigen Säure auf die Eiweissstoffe. Biochem. Zeitsch., 1907, 7, rx.

Trillat. Sur les propriétés antiseptiques de la formaldehyde. Compt. rend., r892, Ix4, 1278 .

\section{THE PRECIPITIN REACTION.}

Blum, L. Über Präzipitine. Zentralbl. f. allgemeine Path. u. path. Anat., rgo6, I7, 8I.

BLume, G. Ueber die Methoden und die bisherigen Ergebnisse der Komplementbindung. Zentralbl. f. Bak. u. Par. I., I907, 40, 609.

Bordet. Sur l'agglutination et dissolution des globules rouges. Ann. de l'Inst. Pasteur, $1899,13,73$.

Gengov. Sur les sensibilatrices des sérums actif contre les substances albuminoides. Ann. de l'Inst. Pasteur, Ig02, I6, 734 .

Hamburger and Arrhenius. Ueber das Wesen der Präzipitinreaktion. Maly's Jahresber., Igo6, 36, 970.

KRAUS. Ueber spezifische Reaktionen in keimfreien Filtraten aus Cholera, Typhus, etc., erzeugt durch homologes Serum. Wiener klin. Wochenschr., 1897, p. 736.

Neisser and Sachs. Ein Verfahren zum forensischen Nachweis der Herkunft des

Bluts. Berliner klin. Wochenschr., I905, p. I388, 1906, p. 67.

NutTall. Blood, Immunity and Relationship. Cambridge, 1904 .

Obermayer and Pick. Beiträge zur Kenntniss der Präzipitinbildung. Wiener klin. Wochenschr., IgO2, no. 22.

Obermayer and Pick. Ueber die chemischen Grundlagen der Arteigenschaften der Eiweisskörper. Wiener klin. Wochenschr., 1906, no. I2.

Schulz, A. Die Technik quantitativer Eiweissbestimmung, mit Hilfe der Präzipitinreaktion. Zeit. z. Unters. der Nahrungs- u. Genussmittel, I9o6, 12, 257.

ScHÖтZE. Ueber ein biologisches Verfahren zur Differenzierung der Eiweissstoffe in verschiedenen Milcharten. Zeit. f. Hygiene, Igor, 36, 55 .

Tschistowitsch. Étude sur l'immunisation contre le sérum d'anguille. Ann. de l'Inst. Pasteur, $1899,13,406$.

UhLENHUtн. Neuer Beitrag zum spezifischen Nachweiss von. Eiwciss auf biologischem Weg. Deutsche med. Wochenschr., rgoo, p. 734.

UhLENHUTh. Eine neue Method zur Unterschidung der verschiedenen Blutarten. Deutsche med. Wochenschr., Igor, pp. 82, 260 and 780 .

WaSSERMANN AND SchüTzE. Ueber eine neue forensische Methode zur Untersuchung von Menschen- $u$. Thierblut. Deutsche med. Wochenschr., Igo2, no. 27.

Wassermann and Schütze. Ueber die Spezificität der Eiweisspräzipitierenden Sera und deren Werthbestimmung für die Praxis. Deutsche med. Wochenschr., rgo3, no. 15 .

Welsh and Chapman. The Main Source of "Precipitable" Substance and on the rôle of the Homologous Proteid in Precipitin Reactions. Proc. Roy. Soc., rgo6, 78в, 297. 


\section{INDEX.}

Acetone, from oxidation of proteins, 60 . Acid and basic functions of proteins, 3-6, 39 . Acidity of filtrates, after precipitation of proteins in presence of acids, $46,47$.

Acids and alkalis, influence on coagulation of proteins, 22.

Aleurone grains, $\mathrm{r} 8$.

Amide-nitrogen, 34 .

Amino-index of proteins, 6,67 .

Ammonium sulphate as albumin precipitant, 9 .

Brological methods for investigating proteins, $7 \mathrm{r}-77$.

Biuret reaction, 30 .

Blood precipitins, 7 I.

Bromine derivatives of proteins, 62,63 .

Carbohydrate group in proteins, $3 \mathrm{I}$.

Caseinogen, salt formation of, $50,5 \mathrm{I}$.

Chemical characterisation of proteins, 6 .

- composition of proteins, 32 .

Chlorine derivatives of proteins, 6r, 62 .

Chromo-proteins, 33.

Colloids, $\mathrm{r}$.

Colour reactions of proteins, $3 \mathbf{I}$.

Complement removing action, 76 .

Concentration cells, use of, in investigating salt formation of proteins, 39 .

Copper compounds of proteins, 56 .

Cryoscopic methods for determining molecular weight, 24 .

Crystallisation of proteins, r6-2r.

Cystine factor of proteins, 6,36 .

DÉNIS, protein investigations of, $\mathbf{r}$.

Depression of freezing-point by proteins, 24 .

EDESTIN, preparation of, 19.

- salt formation of, 47-50.

Egg-albumin, crystallisation of, $\mathbf{r g}$.

- - salt formation of, 40-42.

Electrolytic conductivity of proteins, 26, 39, 40-42.

Formaldehyde, action on proteins, 69, 70 .

Fractional filtration of proteins, 28.

- precipitation of proteins, 8-I5.

Freezing-point of protein solutions, 24, 39, 44 .

Globulins, 9.

Glyco-proteins, 3r, 33.

"Gold number " of proteins, 27.

Gorgonin, 38.

Gum-mastic, precipitant of proteins, I7.
HÆMOGLOBIN, crystallisation of, $2 \mathbf{r}$.

Halogens, action on proteins, $6 r-67$.

- content in protein, 37 .

- protein derivatives, 6.

Heat-coagulation temperature of proteins, 2I-24.

Heavy metals, precipitation of proteins by salts of, $56-58$.

Humin nitrogen, 34 .

Hydrolysis of cane-sugar and methyl acetate in presence of proteins, 39, 42-44.

INORGANIC solvents of proteins, $r 8$.

Iodine derivatives of proteins, 63,64 .

Iodoproteins (natural), 37.

Isolation of proteins, $\mathbf{r}$.

KYROPROTEIC acid, 59.

LIEBIG'S views on proteins, 2.

MAGNesium sulphate as globulin precipitant, 9 .

Milk, separation of protein constituents of, 9.

Mulder's views on proteins, 2.

Myosins, 9.

Nitrogen content and distribution in proteins, 32-36.

Nitrous acid, action on proteins, 67 .

Nucleo-proteins, 33.

OPTICAL rotation of proteins, 24 .

Organic solvents of proteins, 16 .

Osmometers, 26.

Osmotic pressure of proteins, direct determination of, 25 .

Oxaluramide from proteins, 60.

Oxidation of proteins by hydrogen peroxide and ozone, 60.

- - by nitric acid, $6 r$.

- - by permanganate, 59 .

Oxyprotein, 6o.

Oxyprotosulphuric acid, 59.

Peptones, precipitation of by salts, 9 .

Peroxyproteic acid, 59.

Phosphorus content of proteins, 37 .

Polypeptides, 3 .

Precipitants of proteins, 30 .

Precipitin reaction, 71-76.

Prosthetic groups, 3,32 .

Protamines, $32,33,39$.

Proteoses from Witte's peptone, II.

Pseudo-acids and bases, proteins considered as, 55,56 . 


\section{INDEX}

Qualitative distinctions between proteins, THYroid gland, iodine in, 37.

32.

Titration of proteins, 39,46 .

Tryptophane reactions, $3 \mathrm{I}$.

REACTIONS of proteins, 30-32.

SALT formation of proteins, 39-56.

- solutions, solubility of proteins in, 15 .

"Salting out" of proteins, I, 8-I5.

Salts, precipitating capacity of, Io.

Serum-globulin, salt formation of, 5 I-56.

- - solubility of in salt solutions, 16 .

Serum, separation of protein constituents of, 9 .

Sodium chloride as globulin precipitant, 9. - sulphate, use of, for salting out proteins, 12.

Solubility of proteins in acids and bases,

Sponges, iodine content of, 38 .

Sulphur in proteins, 32,36 .

Tyrosine factor of proteins, 6,38 .

UREA solutions, solubility of proteins in, 17 .

Vitellins, 9.

WITTE's peptone, fractionation of, II, I5.

XANTHoproteic reaction, 30 .

Youk platelets, rg.

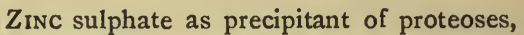
I2. 




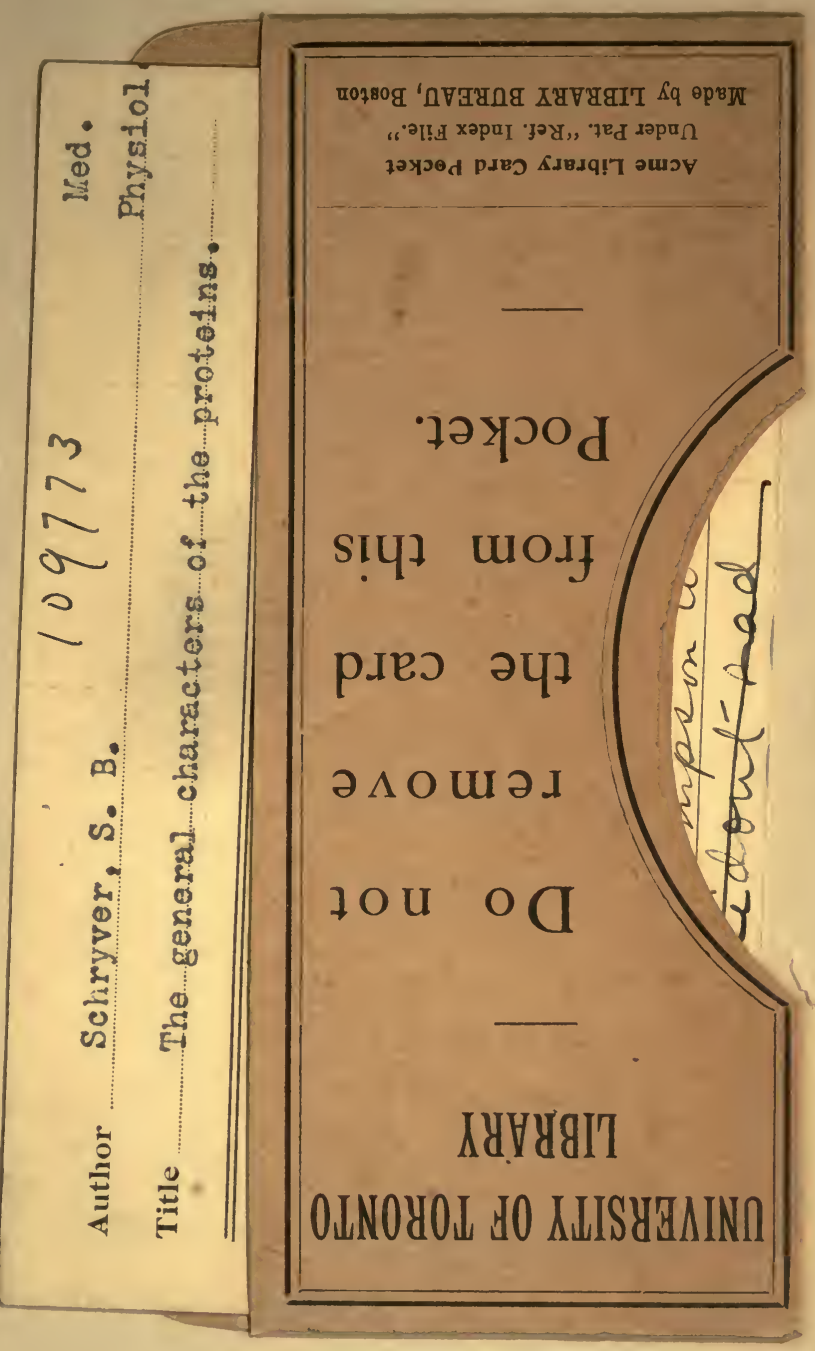


